\title{
NITRIFICAÇÃO DE EFLUENTE DE REATOR ANAERÓBIO \\ COMPARTIMENTADO EM FILTROS PERCOLADORES COM A \\ UTILIZAÇÃO DA SERRAGEM DE COURO DO TIPO WET BLUE \\ COMO MEIO SUPORTE
}

Dissertação apresentada à Escola de Engenharia de São Carlos da Universidade de São Paulo como parte dos requisitos para obtenção do título de Mestre em Engenharia Civil (Hidráulica e Saneamento).

ORIENTADOR: Prof. Tit. Jurandyr Povinelli

SÃO CARLOS 
Dedico esse trabalho a meus pais, Luiz Augusto e Maria de Fátima. Se não fosse por eles, eu não teria chegado até aqui. Amo vocês. 


\section{AGRADECIMENTOS}

Ao Prof. Dr. Jurandyr Povinelli pela orientação, confiança e atenção dispensada durante o desenvolvimento desse trabalho.

À minha família, que foi de fundamental importância na minha formação.

Aos meus irmãos, Mariana e José Augusto pelo apoio, amizade e toda paciência.

Ao meu amor, João Caldas Junior, que acompanhou mais que ninguém cada etapa desse trabalho, uma pessoa que não tenho como agradecer.

À minha Vó Miloca, que sempre me incentivou.

A minha Tia Fátima, que até quando pôde, esteve do meu lado em todos os momentos e grande parte dessa conquista eu devo também a ela.

A todos os professores do departamento de Hidráulica e Saneamento.

Aos funcionários do Laboratório Julio, Paulo, Cidinha e Juliana.

À Eloiza Pozzi, pela ajuda nos exames microscópicos.

À Rose, Sá e Pavi, pela disposição e ajuda sempre prestada.

Ao curtume BMZ Couros Ltda pelo material cedido para o experimento.

À Elizabeth Silva pela correção do português.

Aos meus colegas de orientação Pedro Henrique Carneiro e Gabriel Souto por todo o apoio e sugestões.

Ao Marcelo Dillenburg pela amizade e por todas as situações compartilhadas nesses dois anos de convivência.

Ao Sergio Luiz Moreira por todas as dicas e ajuda na montagem do experimento.

À Ana Beatriz Lima, pela amizade durante todos esses anos e apoio irrestrito durante todos os momentos importantes ou não da minha vida. 
À Roberta Santos Bonini pela verdadeira amizade, pela ajuda até nas situações mais “furadas” e por tornar meus dias mais divertidos.

Ao Emilio Cavalcanti pelo apoio incondicional em todos os momentos.

Aos meus amigos da República Rapadura, República Quebradera, às amigas do futsal e aos meus amigos: Luiz Sergio, Carol, Tatê, Bel, Ju e Gabi por todo apoio e momentos de descontração.

Ao Conselho Nacional de Desenvolvimento Científico e Tecnológico (CNPq) pela concessão da bolsa de estudo.

À Fundação de Amparo à Pesquisa do Estado de São Paulo (FAPESP), pelos recursos financeiros para a pesquisa.

A todos aqueles que de alguma forma contribuíram para a realização desse trabalho. 
"Não sabendo que era impossível, ele foi lá e fez." (Antoine De Saint-Exupery) 



\section{RESUMO}

FRANCHIN, A.C. (2006) Nitrificação de efluente de reator anaeróbio compartimentado em filtros percoladores com a utilização da serragem de couro do tipo wet blue como meio suporte. Dissertação de Mestrado. Escola de Engenharia de São Carlos, Universidade de São Paulo.

Com a utilização de filtros percoladores aeróbios, procurou-se promover a remoção de nitrogênio amoniacal do esgoto sanitário efluente de reator anaeróbio compartimentado, através do processo de nitrificação. O trabalho foi desenvolvido em duas fases; na primeira foi realizada a preparação da serragem de couro utilizando-se peneiramento e lavagens e a seguir iniciou-se a aplicação do esgoto sanitário em quatro filtros percoladores. Os filtros F1 e F2 foram operados com a mesma taxa de aplicação $\left(1,91 \mathrm{~m}^{3} / \mathrm{m}^{2}\right.$. dia) e diferentes meios suportes, sendo brita e serragem de couro do tipo wet blue respectivamente. Os filtros F3 e F4 foram preenchidos com serragem de couro e operaram com taxa de aplicação hidráulica de 4,00 e $6,00 \mathrm{~m}^{3} / \mathrm{m}^{2}$.dia . O filtro F3 apresentou melhores eficiências de remoção para todos os parâmetros, com eficiência média de remoção de $\mathrm{NTK}, \mathrm{N}-\mathrm{NH}_{3}$ e DQO de 71\%; sendo que a partir do $64^{\circ}$ (sexagésimo quarto dia), esse filtro passou a apresentar 100\% de remoção de NTK e N-NH$H_{3}$. Os filtros F1 e F2 podem ter tido problemas com a aeração, já que foram operados com menores taxas de aplicação hidráulica e deveriam apresentar melhores resultados. O filtro F4 apresentou baixas eficiências de remoção, provavelmente devido a maior taxa de aplicação hidráulica.

Palavras chaves: nitrificação, pós-tratamento, serragem de couro, filtro percolador. 


\section{ABSTRACT}

FRANCHIN, A.C. (2006) Nitrification of Anaerobic Baffed Reactor effluent into trickling filters using wet blue leather sawing as a filter packing. M.Sc. Dissertation. Escola de Engenharia de São Carlos, Universidade de São Paulo

The aim of the work is to promote the ammoniacal nitrogen removal from anaerobic baffed reactor effluent using aerobic trickling filters, through the nitrification process. The research was developed in two phases; firstly the leather sawing was prepared through sieving and washing, later the domestic sewage was applied into four tricking filters. The F1 and F2 filters were operated with the same hydraulic loading $\left(1,91 \mathrm{~m}^{3} / \mathrm{m}^{2}\right.$.day) and different filter packing. For the F1 filter was used rock and for the F2 wet blue leather sawing. The F3 and F4 filters were filled with leather sawing and operated in a hydraulic loading of 4,00 and 6,00 $\mathrm{m}^{3} / \mathrm{m}^{2}$.day respectively. The F3 filter presented better removal efficiencies for all the parameters, with 70\% of average removal efficiency of KTN (Kjeldahl Total Nitrogen), $\mathrm{NH}_{3}-$ $\mathrm{N}$ (ammoniacal nitrogen) and COD (Chemical Oxygen Demand). From the $49^{\text {th }}$ day on, this filter presented $100 \%$ of removal efficiency of $\mathrm{KTN}$ and $\mathrm{NH}_{3}-\mathrm{N}$. The $\mathrm{F} 1$ and F2 filter were supposed to present better results due to the lower hydraulic loading, but it did not happen, probably because the aeration was not enough. The F4 filter presented low removal efficiency, possibly due to the higher hydraulic loading.

Key words: nitrification, post-treatment, leather sawing, trickling filters 


\section{LISTA DE TABELAS}

Tabela 1 - Características dos diferentes tipos de filtros biológicos aeróbios

Tabela 2 - Parâmetros determinados para caracterização da serragem de couro bruta do tipo wet blue

Tabela 3 - Parâmetros físicos, químicos e biológicos do esgoto afluente do reator compartimentado.....

Tabela 4 - Características e condições operacionais dos filtros percoladores

Tabela 5 - Análises e freqüências dos principais parâmetros monitorados durante os experimentos.

Tabela 6 - Parâmetros determinados para a lavagem da serragem de couro em solução alcalina.

\section{TABELAS - ANEXO}

Tabela A 1 - pH do esgoto sanitário afluente e efluente dos filtros percoladores

Tabela A 2 - Condutividade do esgoto sanitário afluente e efluente dos filtros percoladores $(\mathrm{mS} / \mathrm{cm})$

Tabela A 3 - Turbidez do esgoto sanitário afluente e efluente dos filtros percoladores (UNT)

Tabela A 4 - Eficiência de remoção de turbidez nos filtros percoladores (\%) .58

Tabela A 5 - Alcalinidade Total do esgoto sanitário afluente e efluente dos filtros percoladores $\left(\mathrm{mg} \mathrm{CaCo}_{3} / \mathrm{L}\right)$.

Tabela A 6 - Concentração de NTK do esgoto sanitário afluente e efluente dos filtros percoladores $(\mathrm{mg} / \mathrm{L})$

Tabela A 7 - Eficiência de remoção de NTK nos filtros percoladores (\%). .59

Tabela A 8 - Concentração de nitrogênio amoniacal (mg/L)

Tabela A 9 - Eficiência de remoção de nitrogênio amoniacal (\%).

Tabela A 10 - Concentração de nitrato do esgoto sanitário afluente e efluente dos filtros percoladores $(\mathrm{mg} / \mathrm{L})$

Tabela A 11 - Concentração de nitrito do esgoto sanitário afluente e efluente dos filtros percoladores (mg/L)

Tabela A 12 - Concentração de DQO total do esgoto sanitário afluente e efluente dos filtros percoladores $(\mathrm{mg} / \mathrm{L})$

Tabela A 13 - Eficiência de remoção de DQO total do esgoto sanitário afluente e efluente dos filtros percoladores $(\%)$......

Tabela A 14 - Concentração de DQO filtrada do esgoto sanitário afluente e efluente dos filtros percoladores $(\mathrm{mg} / \mathrm{L})$.

Tabela A 15 - Eficiência de remoção de DQO filtrada do esgoto sanitário afluente e efluente dos filtros percoladores (\%). 
Tabela A 16 - Concentração de $\mathrm{DBO}_{5}$ do esgoto sanitário afluente e efluente dos filtros percoladores $(\mathrm{mg} / \mathrm{L})$.

Tabela A 17 - Eficiência de remoção de $\mathrm{DBO}_{5}$ do esgoto sanitário afluente e efluente dos filtros percoladores (\%).

Tabela A 18 - Número mais provável de coliformes totais do esgoto sanitário afluente e efluente dos filtros percoladores (NMP/100 ml)

Tabela A 19 - Eficiência de remoção de coliformes totais do esgoto sanitário afluente e efluente dos filtros percoladores (\%)

Tabela A 20 - Número mais provável de coliformes fecais do esgoto sanitário afluente e efluente dos filtros percoladores (NMP/100 ml)

Tabela A 21 - Eficiência de remoção de coliformes fecais do esgoto sanitário afluente e efluente dos filtros percoladores (\%)

Tabela A 22 - Concentração de sólidos totais do esgoto sanitário afluente e efuente dos filtros percoladores $(\mathrm{g} / \mathrm{L})$.

Tabela A 23 - Concentração de sólidos totais fixos do esgoto sanitário afluente e efluente dos filtros percoladores $(\mathrm{g} / \mathrm{L})$

Tabela A 24 - Concentração de sólidos totais voláteis do esgoto sanitário afluente e efluente dos filtros percoladores $(\mathrm{g} / \mathrm{L})$.

Tabela A 25 - Concentração de sólidos suspensos totais do esgoto sanitário afluente e efluente dos filtros percoladores $(\mathrm{g} / \mathrm{L})$

Tabela A 26 - Concentração de sólidos suspensos fixos do esgoto sanitário afluente e efluente dos filtros percoladores $(\mathrm{g} / \mathrm{L})$. 66

Tabela A 27 - Concentração de sólidos suspensos voláteis do esgoto sanitário afluente e efluente dos filtros percoladores $(\mathrm{g} / \mathrm{L})$. 


\section{LISTA DE FIGURAS}

Figura 1 - Transformação do nitrogênio nos processos de tratamento biológicos .................... 4

Figura 2 - Operações e processos da transformação da pele crua em couro curtido.................14

Figura 3 - Vista geral da rebaixadeira e da serragem de couro ...........................................16

Figura 4 - Serragem de couro do tipo wet blue utilizada como meio suporte .........................20

Figura 5- Representação esquemática do reator anaeróbio compartimentado.........................22

Figura 6 - Filtros percoladores utilizados para o pós-tratamento de efluente de reator

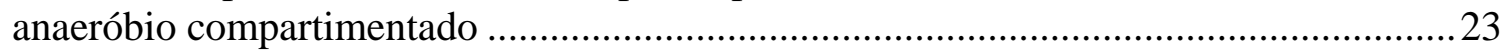

Figura 7 - Vista Superior do sistema de distribuição do esgoto afluente aos filtros percoladores

Figura 8 - Representação esquemática da instalação experimental

Figura 9 - Variação temporal do pH do esgoto sanitário afluente e efluente dos filtros percoladores.

Figura 10 - Variação temporal da condutividade do esgoto sanitário afluente e efluente dos filtros percoladores

Figura 11 - Variação temporal de turbidez do esgoto sanitário afluente e efluente dos filtros percoladores.

Figura 12 - Variação temporal da alcalinidade total do esgoto afluente e efluente dos filtros percoladores

Figura 13 - Variação temporal da concentração de NTK do esgoto sanitário afluente e efluente dos filtros percoladores

Figura 14 - Variação temporal da concentração de nitrogênio amoniacal do esgoto sanitário afluente e efluente dos filtros percoladores

Figura 15 - Variação temporal da concentração de nitrato do esgoto sanitário afluente e

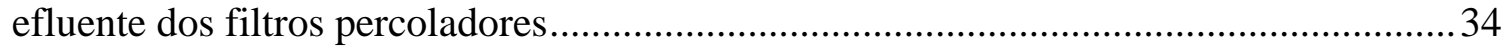

Figura 16 - Variação temporal da concentração de nitrito do esgoto sanitário afluente e

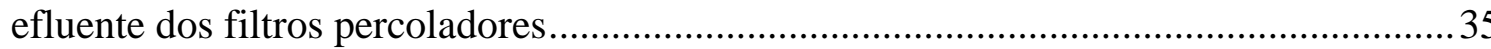

Figura 17 - Variação temporal da concentração de DQO total do esgoto sanitário afluente e

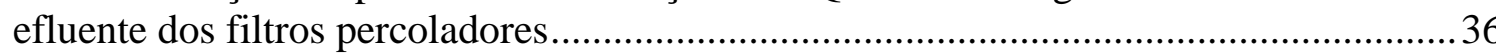

Figura 18 - Variação temporal da concentração de DQO filtrada do esgoto sanitário afluente e

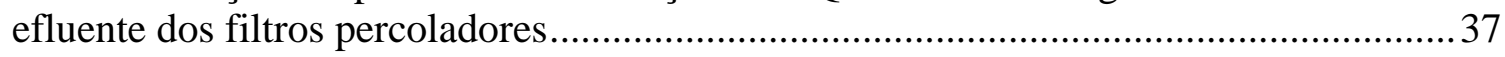

Figura 19 - Variação temporal da concentração de DBO5 do esgoto sanitário afluente e

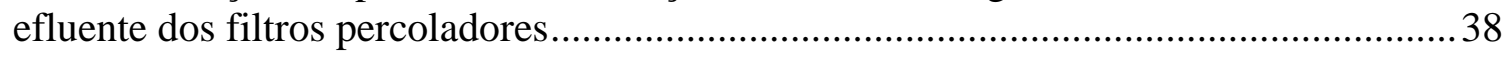

Figura 20 - Número mais provável de coliformes totais do esgoto sanitário afluente e efluente dos filtros percoladores.

Figura 21 - Número mais provável de coliformes fecais do esgoto sanitário afluente e efluente dos filtros percoladores

Figura 22 - Variação temporal da concentração de cromo total do esgoto sanitário afluente e efluente dos filtros percoladores 
Figura 23 - Floco observado na serragem de couro utilizada no filtro percolador ( $6^{\circ}$ dia de operação)

Figura 24 - Amebas observadas na brita utilizada no filtro percolador ( $6^{\circ}$ dia de operação) . 43

Figura 25 - Protozoário flagelado observado na brita utilizada no filtro percolador ( $6^{\circ}$ dia de operação)

Figura 26 - Bacilos observados na serragem de couro utilizada no filtro percolador ( $41^{\circ}$ dia)

Figura 27 - Protozoário flagelado observado na serragem de couro utilizada no filtro percolador $\left(41^{\circ}\right.$ dia $)$.

Figura 28 - Protozoário pedunculado observado na serragem de couro utilizada no filtro percolador ( $\left.41^{\circ} \mathrm{dia}\right)$. 45

Figura 29 - Bacilos coloniais observados na brita utilizada no filtro percolador ( $41^{\circ}$ dia) .... 45

Figura 30 - Microrganismo semelhante à Beggiatoa observada na serragem de couro utilizada

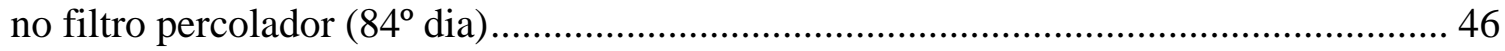

Figura 31 - Amebas com carapaças observadas na brita utilizada no filtro percolador ( $84^{\circ}$ dia) 47

Figura 32 - Rotífero observado na brita utilizada no filtro percolador ( $84^{\circ}$ dia) 47 


\section{LISTA DE ABREVIATURAS E SÍMBOLOS}

$\mathrm{N}-\mathrm{NH}_{3}$ : Nitrogênio na forma amoniacal

$\mathrm{N}-\mathrm{NH}_{4}^{+}$: Nitrogênio na forma de íon amônio

$\mathrm{N}-\mathrm{NO}_{2}{ }^{-}$: Nitrogênio na forma de nitrito

$\mathrm{N}-\mathrm{NO}_{3}{ }^{-}$: Nitrogênio na forma de nitrato

O.D: Oxigênio dissolvido

TRC: Tempo de retenção celular

C/N: Relação carbono/nitrogênio

DBO: Demanda Bioquímica de Oxigênio

NTK: Nitrogênio Total Kjeldahl

DQO: Demanda Química de Oxigênio

PVC: policloreto de vinila

h: altura

d: diâmetro

$\mathrm{V}$ : volume

LTR: Laboratório de Tratamento de Resíduos

UNT: Unidade nefelométricas de turbidez

NMP: Número mais provável

CETESB: Companhia de Tecnologia de Saneamento Ambiental

CONAMA: Conselho Nacional do Meio Ambiente

F/M: Relação food/microrganism (alimento/microrganismo) 


\section{SUMÁRIO}

1 INTRODUCÃ̃O E JUSTIFICATIVA

3.1.1 FATORES AMBIENTAIS QUE INTERFEREM NO PROCESSO

3.1.2 RESULTADOS OBTIDOS COM A UTILIZAÇÃO DA SERRAGEM DE COURO CURTIDO COMO MATERIAL SUPORTE EM FILTROS PERCOLADORES

3.2.1 CARACTERÍSTICAS DOS COMPONENTES PRINCIPAIS DE UM FILTRO AERÓBIO

3.2.2 CLASSIFICAÇÃO DOS FILTROS BIOLÓGICOS

3.2.3 MICRORGANISMOS PRESENTES NOS FILTROS

3.3 SERRAGEM DE COURO

3.3.1 PANORAMA DO SETOR DE COURO DO BRASIL

3.3.2 PROCESSAMENTO DO COURO

3.3.3 PRINCIPAIS SÓLIDOS GERADOS EM CURTUME

3.3.4 ALGUNS EMPREGOS PARA A SERRAGEM DE COURO 
3.4.3 TOXICIDADE DO CROMO SOBRE OS MICRORGANISMOS ENVOLVIDOS NOS PROCESSOS BIOLÓGICOS

4.1 PRIMEIRA FASE - PREPARAÇÃo DA SERRAGEM DE COURO 20

4.2 SEGUNDA FASE - APLICAÇÃO DO EFLUENTE NOS FILTROS PERCOLADORES 21

4.2.1 REATOR COMPARTIMENTADO

4.2.2 FiltROS PERCOLADORES 22

4.2.3 CARACTERÍSTICAS E OPERAÇÃO DOS FILTROS 23

4.2.4 MONITORAMENTO 25

5.2 SEGUNDA FASE - APLICAÇÃO DO EFLUENTE NOS FILTROS PERCOLADORES 27

5.2.1 $\mathrm{PH}$ 27

5.2.2 CONDUTIVIDADE 28

5.2.3 TURBIDEZ 29

5.2.4 Alcalinidade Total 30

5.2.5 NitRoGÊNIO TOTAL KJELDAHL 31

5.2.6 NitRoGÊNIO AMONIACAL 32

5.2.7 NITRATO 33

5.2.8 NITRITO 34

5.2.9 DQO TOTAL 35

5.2.10 DQO FILTRADA 36

5.2.11 $\mathrm{DBO}_{5}$ 37 
5.2.12 COLIFORMES TOTAIS 38

5.2.13 COLIFORMES FECAIS 39

$\begin{array}{lll}5.2 .14 & \text { SÓLIDOS } & 40\end{array}$

$\begin{array}{lll}\text { 5.2.15 СROMO } & 40\end{array}$

5.2.16 OUTROS METAIS $\quad 41$

5.2.17 MICROSCOPIA ÓPTICA $\quad 42$

6 CONCLUSÕES $\quad 48$

$\underline{7}$ RECOMENDACÕES

$\underline{8}$ REFERÊNCIAS BIBLIOGRÁFICAS

\begin{tabular}{lr} 
ANEXO & 56 \\
\hline
\end{tabular} 


\section{INTRODUÇÃO}

O crescimento populacional aliado ao desenvolvimento industrial têm ocasionado efeitos negativos sobre o ambiente, tais como a poluição e degradação dos recursos naturais. O lançamento de efluentes industriais (especialmente de indústrias de alimentos) e domésticos são as principais fontes poluidoras de matéria orgânica e nutriente (principalmente nitrogênio e fósforo), que quando presentes em grande quantidade provocam aumento da produção primária e causam desequilíbrio no ecossistema.

Em decorrência da decomposição da matéria orgânica há formação de compostos nitrogenados reduzidos, como por exemplo, a amônia, que em solução pode estar em equilíbrio tanto na forma de íon $\left(\mathrm{NH}_{4}^{+}\right)$como na forma livre, não ionizada $\left(\mathrm{NH}_{3}\right)$. A presença desses compostos nos corpos receptores pode trazer grandes implicações ecológicas, pois influi fortemente na dinâmica de oxigênio dissolvido do meio, além de causar toxicidade aos peixes e provocar a proliferação excessiva de algas. Portanto, verifica-se a necessidade de se remover nutrientes dos efluentes antes de lançá-los nos rios.

A nitrificação é um dos processos mais comuns e mais econômicos de remoção de amônia e nitrito das águas residuárias e é realizado por dois grupos de bactérias que oxidam a amônia a nitrato.

Face ao exposto, o presente trabalho buscou através da utilização de filtros percoladores aeróbios, promover a nitrificação do esgoto sanitário efluente de reator anaeróbio compartimentado. Como meio suporte foi utilizado a serragem de couro do tipo wet blue, um resíduo das indústrias de curtimento do couro; portanto, a sua utilização para algum fim lucrativo do ponto de vista ambiental é de grande importância, diminuindo assim os riscos e problemas causados pela sua disposição inadequada.

Tendo em vista excelentes resultados obtidos em pesquisas anteriores desenvolvidas na 
Universidade Federal do Rio Grande do Sul por Souza (1999) e na Escola de Engenharia de São Carlos por Moreira (2003) e Suassuna (2004), este trabalho visou aprimorar e ampliar os conhecimentos nessa linha de pesquisa através da utilização de serragem de couro como meio suporte em filtros percoladores. 


\section{OBJETIVOS}

\subsection{OBJETIVO GERAL}

O objetivo geral foi avaliar a ocorrência do processo de nitrificação de efluente de reator anaeróbio compartimentado em filtros percoladores com leito preenchido por serragem de couro do tipo wet blue.

\subsection{OBJETIVOS ESPECÍFICOS}

a. Verificar a eficiência dos filtros percoladores para diferentes taxas de aplicação hidráulica.

b. Comparar a eficiência na remoção de matéria orgânica e nitrogênio em um filtro preenchido apenas com brita, e um filtro preenchido com uma dupla camada de brita e serragem de couro, operados com a mesma taxa de aplicação hidráulica.

c. Comparar os microrganismos presentes no leito de brita e no leito de serragem de couro através de microscopia óptica. 


\section{REVISÃo BIBLIOGRÁFICA}

\subsection{NITRIFICAÇÃO}

Nos últimos anos, o ciclo do nitrogênio tem recebido muita atenção em função do seu significado ambiental no efeito estufa, na chuva ácida e na eutrofização das águas (WIJFFELS \& TRAMPER, 1995). No decorrer da transformação biológica do nitrogênio, ocorrem reações de amonificação, assimilação, nitrificação e desnitrificação, as mesmas podem ser observadas na Figura 1 .

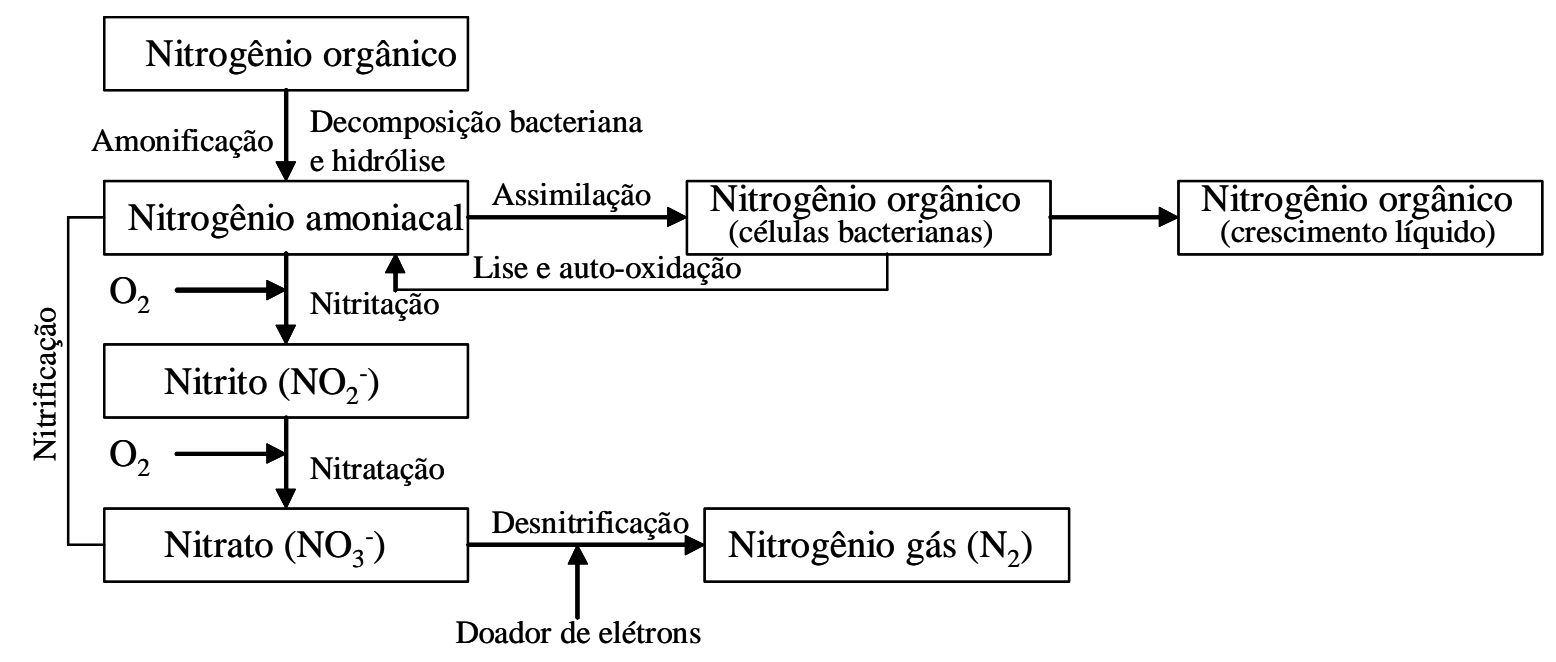

Fonte: Adaptado de Seldlak(1991)

Figura 1 - Transformação do nitrogênio nos processos de tratamento biológicos

Nesse processo, a nitrificação destaca-se como o fenômeno da oxidação do nitrogênio amoniacal a nitrato $\left(\mathrm{NO}_{3}^{-}\right)$com a formação intermediária de nitrito $\left(\mathrm{NO}_{2}^{-}\right)$. A nitrificação é um processo aeróbio realizado por dois grupos de bactérias autótrofas e que utilizam carbono inorgânico como fonte de carbono.

Na primeira etapa do processo, ou seja, na oxidação da amônia a nitrito, os principais microrganismos envolvidos no processo são as bactérias dos gêneros Nitrosomonas ( $N$. europaea e $N$. monocella) e Nitrosococcus. No entanto, dentre as Nitrosomonas, a $N$. europaea, tem sido a mais estudada e escolhida como gênero representante (BARNES \& 
BLISS, 1983). A equação (1) mostra de forma simplificada a etapa de oxidação do íon amônio a nitrito.

$$
\mathrm{NH}_{4}^{+}+1,5 \mathrm{O}_{2} \stackrel{\text { Nitrosonomas }}{\longrightarrow} \mathrm{NO}_{2}^{-}+\mathrm{H}_{2} \mathrm{O}+2 \mathrm{H}^{+} \quad \Delta \mathrm{G}^{\mathrm{o}}=-51,8 \mathrm{Kcal}
$$

Na segunda etapa do processo, na qual o nitrito é oxidado a nitrato, os principais microrganismos participantes do processo são dos gêneros Nitrobacter ( $N$. agilis e $N$. winogradskyi) e Nitrosocystis. A espécie $N$. agilis é a mais encontrada nos sistemas de tratamento, portanto, convencionou-se representar os microrganismos oxidantes de nitrito pelo gênero Nitrobacter (BARNES \& BLISS, 1983). A equação 0,1 Kcal apresenta a oxidação do nitrito a nitrato.

$$
\mathrm{NO}_{2}^{-}+0,5 \mathrm{O}_{2} \stackrel{\text { Nitrobacter }}{\longrightarrow} \mathrm{NO}_{3}^{-} \quad \Delta \mathrm{G}^{\mathrm{o}}=-20,1 \mathrm{Kcal}
$$

Além dos microrganismos autótrofos nitrificantes, muitos organismos heterótrofos são capazes de produzir formas oxidadas de nitrogênio a partir da amônia, entretanto menos significativas em sistemas naturais.

Para a efetiva remoção de nitrogênio, o nitrato deve ser reduzido a $\mathrm{N}_{2}$, processo realizado pelos organismos desnitrificantes que necessitam de condições anaeróbias e uma fonte externa de carbono.

\subsubsection{Fatores ambientais que interferem no processo}

Para que os sistemas biológicos de nitrificação operem satisfatoriamente, é necessário atender a alguns requisitos relativos ao $\mathrm{pH}$ (potencial hidrogeniônico), à presença de O.D (oxigênio dissolvido), ao TRC (tempo de retenção celular), à temperatura, à concentração de nitrogênio amoniacal e à relação C/N (Carbono/Nitrogênio) adequada (FORD et al, 1980; SURAMPALLI et al, 1997). 


\section{- $\boldsymbol{p H}$}

O efeito do $\mathrm{pH}$ na nitrificação é significante e faixas ótimas são citadas por diversos autores, entre as quais: 8,0 - 9,0 (HENZE et al.,1997); 7,5 - 8,6 (METCALF E EDDY, 2003) e 7,2 - 9,0 (ROJAS, 1999). No entanto, sistemas com condições mais baixas de pH têm obtido sucesso no processo de nitrificação.

Deve-se tomar cuidado com reatores de filme fixo, pois os valores de $\mathrm{pH}$ observados na fase líquida podem ser diferentes dos valores reais no biofilme (HENZE et al., 1997).

\section{- Alcalinidade}

O efeito da nitrificação sobre a alcalinidade, produção celular e consumo de oxigênio pode ser descrito por simples relações estequiométricas, como a equação (3) global apresentada por Henze et al. (1997), na qual a fórmula $\mathrm{C}_{5} \mathrm{H}_{7} \mathrm{NO}_{2}$ representa a composição das células.

$$
\mathrm{NH}_{4}^{+}+1,86 \mathrm{O}_{2}+1,98 \mathrm{HCO}_{3}^{-} \Leftrightarrow 0,02 \mathrm{C}_{5} \mathrm{H}_{7} \mathrm{NO}_{2}+0,98 \mathrm{NO}_{3}^{-}+1,88 \mathrm{H}_{2} \mathrm{CO}_{3}+1,04 \mathrm{H}_{2} \mathrm{O}
$$

Para a manutenção de valores de $\mathrm{pH}$ em níveis aceitáveis, é necessário adicionar alcalinidade ao sistema, sendo que a quantidade depende da concentração da alcalinidade inicial e a quantidade do íon amônio a ser oxidado. Aproximadamente 7,14mg de alcalinidade são necessários para cada 1mg de nitrogênio amoniacal oxidado (SURAMPALLI et al., 1997).

\section{- Oxigênio dissolvido}

Segundo Barnes \& Bliss (1983), a concentração de O.D. crítica, abaixo da qual a nitrificação não se processa, encontra-se em torno de $0,2 \mathrm{mg} / \mathrm{L}$. No entanto, valores mais elevados devem ser mantidos no tanque de aeração, para garantir que em pontos de difícil acesso ao oxigênio, seja mantida concentração superior à crítica. Segundo Surampalli et al., (1997), a taxa máxima de nitrificação ocorre para valores de O.D superiores a 2mg/L. 
Abreu$^{1}$ (1994) apud Callado e Foresti (2001) citam que em sistemas exclusivamente nitrificantes operados com baixa concentração de O.D ( 0,5mg/L) ocorre acumulação de nitrito e aumenta a velocidade de crescimento das bactérias na nitritação (Nitrossonomas), indicando que as bactérias responsáveis pela nitratação (Nitrobacter) são mais sensíveis às baixas concentrações de O.D.

\section{- Temperatura}

A temperatura ótima para a nitrificação encontra-se na ordem de 30 a $36^{\circ} \mathrm{C}$, porém observou-se a ocorrência do processo numa faixa de 4 a 50 (BARNES \& BLISS, 1983).

Songming \& Chen (2002) estudaram o impacto da temperatura na nitrificação em biofiltros de filme fixo, e concluíram que um incremento na temperatura a $20^{\circ} \mathrm{C}$ resulta num aumento da taxa de nitrificação em 1,108\% e 4,275\% por ${ }^{\circ} \mathrm{C}$ sob condições limitadas de OD e N-NH 3 (Nitrogênio amoniacal) respectivamente, enquanto que essa taxa para crescimento suspenso foi de $8,351 \%$ e $9,577 \%$. Este fato demonstra que organismos imobilizados são menos sensíveis a mudanças de temperatura do que células em suspensão.

\section{- Tempo de retenção celular}

Devido ao baixo rendimento energético das reações de oxidação, o crescimento dos organismos nitrificantes é lento, portanto, é necessário um tempo de retenção celular suficientemente alto para permitir o desenvolvimento desses microrganismos, antes que sejam varridos do sistema.

\section{- Relação carbono/nitrogênio}

Quando a relação $\mathrm{C} / \mathrm{N}$ aumenta, uma ampla área do material suporte é coberta por

1 ABREU, L.M. (1994). Aspectos microbiológicos de los processos de nitrificaciondesnitrificación. In: Taller y seminário latino-americano de tratamento de águas residuales. Montevidéu, Anais Montividéu, p. 55-63 
bactérias heterótrofas e a taxa de nitrificação diminui. Como a taxa de reprodução dos organismos nitrificantes é bem inferior à dos organismos heterótrofos, responsáveis pela estabilização da matéria carbonácea, a nitrificação só ocorrerá para baixos valores de DBO (20 mg/L para início do processo), o que diminui a competição por espaço no biofilme (METCALF \& EDDY, 2003).

\section{- Concentração de nitrogênio amoniacal}

O próprio substrato pode tornar-se inibitório para as bactérias, dependendo da concentração e do meio (FORD et al., 1980). A inibição dos organismos oxidantes de amônia por amônia livre $\left(\mathrm{NH}_{3}\right)$ pode ocorrer a concentrações na faixa de 10 a $150 \mathrm{mg} \mathrm{NH}_{3} / \mathrm{L}$ e para os oxidantes de nitrito, a inibição pode ocorrer na faixa de concentração de 0,1 a 1,0mg $\mathrm{NH}_{3} / \mathrm{L}$. Essa diferença de sensibilidade pode levar ao acúmulo de nitrito (BARNES \& BLISS, 1983).

\subsubsection{Resultados obtidos com a utilização da serragem de couro curtido como material suporte em filtros percoladores}

Alguns autores já utilizaram a serragem de couro como meio suporte em filtros percoladores e obtiveram resultados satisfatórios. Souza (1999) operou um sistema composto por doze unidades, sendo seis filtros percoladores precedidos por seis pré-filtros, todos operados com baixa taxa de aplicação hidráulica. O sistema apresentou ótimo desempenho no tratamento de esgoto sanitário, com elevada remoção de $\mathrm{DBO}_{5}(90 \% \pm 10 \%)$, DQO total $(80 \% \pm 27 \%)$, NTK $(63 \% \pm 33 \%)$ e $\mathrm{N}-\mathrm{NH}_{3}(60 \% \pm 26 \%)$. Paralelamente, houve eliminação completa de coliformes fecais.

Moreira (2003) trabalhou com quatro filtros superiores (remoção de material suspenso) operando em série com quatro filtros inferiores (remoção de material dissolvido). Os quatro primeiros filtros receberam o efluente de um reator compartimentado e os demais receberam o efluente do primeiro. As vazões afluentes ao sistema enquadram-se dentro da faixa utilizada 
para filtro de baixa taxa. Na remoção de nitrogênio, em sua forma amoniacal e total, o sistema a partir do $40^{\circ}$ (quadragésimo) dia de operação, quando se estabeleceu a nitrificação, apresentou eficiências médias de remoção em torno de $80 \% \pm 10 \%$.

Suassuna (2004), na terceira etapa de seu trabalho, operou quatro filtros percoladores como unidades independentes e aeradas (vazão média de ar de 2,0L/min) que receberam efluente de um reator anaeróbio compartimentado. Esses filtros operaram por 120 dias, com TDHs de 10 e 17h, e ao término do $90^{\circ}$ (nonagésimo) dia de operação foi iniciada a alcalinização do esgoto afluente com uso de bicarbonato de sódio. Essa alcalinização fez-se necessária em virtude dos baixos valores de $\mathrm{pH}$ da serragem de couro bruta (em torno de 3,0) e da serragem de couro lavada (em torno de 5,0) e do processo de nitrificação desenvolvido nesses filtros. Nessa fase foram encontradas excelentes reduções de NTK e de nitrogênio amoniacal com eficiências médias de remoção para os dois parâmetros, de $83 \%$ antes da alcalinização e de 100 \% após alcalinização. As concentrações de nitrato no esgoto afluente variaram em torno de 2,0 $\mathrm{mgNO}_{3}{ }^{-} / \mathrm{L}$ e nos efluentes dos filtros percoladores variaram em torno de $30,0 \mathrm{mgNO}_{3}{ }^{-}$ /L, o que mostra claramente a ocorrência do processo de nitrificação nos filtros.

\subsection{FILTROS BIOLÓGICOS AERÓBIOS}

Segundo Campos (1994), o filtro biológico aeróbio consta basicamente de um leito de pedras ou de outros materiais inertes com forma, tamanho e interstícios adequados, que permitem a livre circulação natural ou forçada de ar, sobre o qual dispositivos de distribuição lançam o esgoto sanitário, que percola por entre as peças que constituem o recheio e servem de suporte para os microrganismos. 


\subsubsection{Características dos componentes principais de um filtro aeróbio}

\section{- Sistema Distribuidor}

A distribuição dos despejos sobre a superfície do leito filtrante pode ser feita por meio de aspersores fixos ou móveis. Os sistemas fixos promovem aplicações intermitentes sobre o leito, enquanto que os sistemas móveis rotativos garantem uma distribuição uniforme, atingindo toda a área superficial do leito percolador.

\section{- Leito Filtrante}

O leito dos filtros biológicos deve servir como suporte para os microrganismos, além de fornecer apoio e espaço para permitir a distribuição da vazão e favorecer o contato do esgoto com a película biológica e ar necessário para o processamento das reações aeróbias.

Segundo Pessôa \& Jordão (2005), o meio suporte deve apresentar as seguintes características:

1) inerte, rígido e resistente à degradação química e biológica;

2) leve, pois o peso unitário influi diretamente no cálculo estrutural, no transporte e no manuseio;

3) superfície específica grande o suficiente para reter a biomassa responsável pelo tratamento;

4) considerável volume de vazio para garantir adequado suprimento de oxigênio.

\section{- Sistema Drenante}

O sistema drenante é constituído de blocos ou calhas dispostas em toda a extensão do fundo do filtro, com condições de escoamento contínuo e convergindo para um canal central. Sobre a laje do fundo colocam-se drenos ou peças pré-moldadas de concreto, que deverão ter declividade mínima de 1\% e as calhas devem assegurar velocidade de escoamento superior a 0,60m/s. Os blocos ou calhas devem possuir orifícios cuja área total deve ser igual ou superior 
a 15\% da área da seção transversal do filtro. (BELÉM, 1996)

\subsubsection{Classificação dos filtros biológicos}

A classificação dos filtros biológicos é feita de acordo com a variação das taxas de aplicação hidráulica e de carregamento orgânico, conforme descrito na Tabela 1.

Tabela 1 - Características dos diferentes tipos de filtros biológicos aeróbios

\begin{tabular}{cccc}
\hline Característica & Baixa taxa & Taxa intermediária & Alta taxa \\
\hline $\begin{array}{c}\text { Taxa de aplicação Hidráulica } \\
\left(\mathrm{m}^{3} / \mathrm{m}^{2} \text {.dia }\right)\end{array}$ & $1-4$ & $4-10$ & $10-40$ \\
$\begin{array}{c}\text { Taxa de carregamento orgânico } \\
\left(\mathrm{kgDBO}_{5} / \mathrm{m}^{3} \text {.dia }\right)\end{array}$ & $0,07-0,22$ & $0,24-0,48$ & $0,4-2,4$ \\
Eficiência de remoção de DBO (\%) & $80-90$ & $50-80$ & $50-90$ \\
Qualidade do efluente & bem nitrificado & parcialmente nitrificado & não nitrificado \\
\hline
\end{tabular}

Fonte: adaptada de METCALF \& EDDY (2003)

\section{- Filtros de baixa taxa}

Os filtros de baixa taxa são de operação simples e produzem efluente de boa qualidade, independente das características do afluente. Geralmente são mantidos com taxa de aplicação hidráulica constante, através do uso de sistema de bombeamento e não necessitam de recirculação.

As partes inferiores desses filtros podem ser habitadas por bactérias autotróficas nitrificantes, que oxidam o nitrogênio amoniacal para as formas de nitrito e nitrato. Quando essas populações estão bem estabelecidas e o controle operacional é adequado, o efluente é altamente nitrificado (METCALF \& EDDY, 2003).

As principais desvantagens estão relacionadas à ocupação de maior área e volume, maior perda de carga e maior incidência de insetos e odor.

\section{- Filtros de taxa intermediária e de alta taxa}

Esses filtros são empregados com altas taxas de carregamento orgânico e aplicação 
hidráulica, o que provoca grande arraste de sólidos e, conseqüentemente, grande perda de material orgânico em suspensão.

Nos filtros de alta taxa é comum o emprego da recirculação do efluente para promover a uniformização na distribuição das cargas aplicadas e permitir a adaptação dos microrganismos ao meio, além de evitar a colmatação do leito filtrante, problemas de odor e a proliferação de moscas (METCALF \& EDDY, 2003).

\subsubsection{Microrganismos presentes nos filtros}

As bactérias facultativas são os microrganismos predominantes nos filtros biológicos e, juntamente com as bactérias aeróbias e anaeróbias são os principais responsáveis pela decomposição da matéria orgânica presente nas águas residuárias. Achromobacter sp, Flavobacterium sp, Pseudonomas sp e Alcaligenes sp são as espécies mais encontradas nos filtros biológicos.

Além das bactérias são encontrados fungos, algas, protozoários e até alguns animais superiores como vermes, larvas de insetos e moluscos.

Segundo Grady e Lim (1981), mais de 90 espécies de fungos foram relatadas, das quais mais de 20 foram consideradas membros da população microbiana predominante nos filtros. Os fungos podem reproduzir-se em condições mais ácidas e de maiores relações $\mathrm{C} / \mathrm{N}$, comparados com as bactérias.

A camada superior do meio suporte dos filtros biológicos, sendo exposta à luz, proporciona condições ideais para o crescimento de algas. Nos meses de verão, as algas podem formar uma extensa cobertura verde na superfície dos filtros (HORAN, 1990). Tal autor afirma que os protozoários são abundantes nos filtros biológicos e mais de 200 espécies já foram identificadas.

A superfície dos filtros mostra uma limitada fauna de protozoários, constituída principalmente por amebas e flagelados, ao passo que uma ampla variedade é encontrada nas 
regiões mais profundas.

\subsection{SERRAGEM DE COURO}

\subsubsection{Panorama do setor de couro do Brasil}

De acordo com a Revista Courobusiness (2004a), a produção Brasileira de couros estimada em 2003 foi de 35,50 milhões de peças e a participação brasileira na produção de couro mundial, saltou de 7,70\%, (1991), para 10,77\% (2003).

Em 2003, o Brasil exportou 22,6 milhões de unidades de couro, dos quais 21,9 de origem bovina, sendo 13,6 do tipo wet blue (serragem de couro curtida ao cromo), segundo a Revista Courobusiness (2004b).

Segundo a CETESB (1980), a produção de serragem de couro do tipo wet blue (resíduo originado na operação de rebaixamento do couro curtido) varia entre 150 a $180 \mathrm{~kg}$ por tonelada de pele processada, sendo esta, uma quantidade considerável. Desse modo, há a necessidade de se estudar uma alternativa de tratamento para esse tipo de resíduo, classificado segundo a NBR 10004 como resíduo classe I - Perigoso, devido à elevada concentração de cromo.

\subsubsection{Processamento do couro}

Antes de qualquer conceituação do que sejam subprodutos ou resíduos de curtume, é necessário que se coloquem algumas noções básicas sobre as operações e processos de transformação das peles em couro acabado, com a finalidade de se destacar a fonte desses resíduos, a importância do seu tratamento e a sua inevitável produção (MYLIUS² et al., 1974

2 MYLUS, S.; DIETRICH, O.E.; GARLIPP FILHO, P. (1974). Projeto 23.03.03. Levantamento estatístico e estudo da viabilidade econômica e industrial de subprodutos de curtumes - Novo Hamburgo, IBCCA 
apud BIDONI, 1995).

De modo geral, as operações e processos de transformação de peles em couro acabado apresentam as etapas básicas de ribeira, curtimento e acabamento. As mesmas podem ser representadas na Figura 2 (HOINACK \& MOREIRA, 1994).

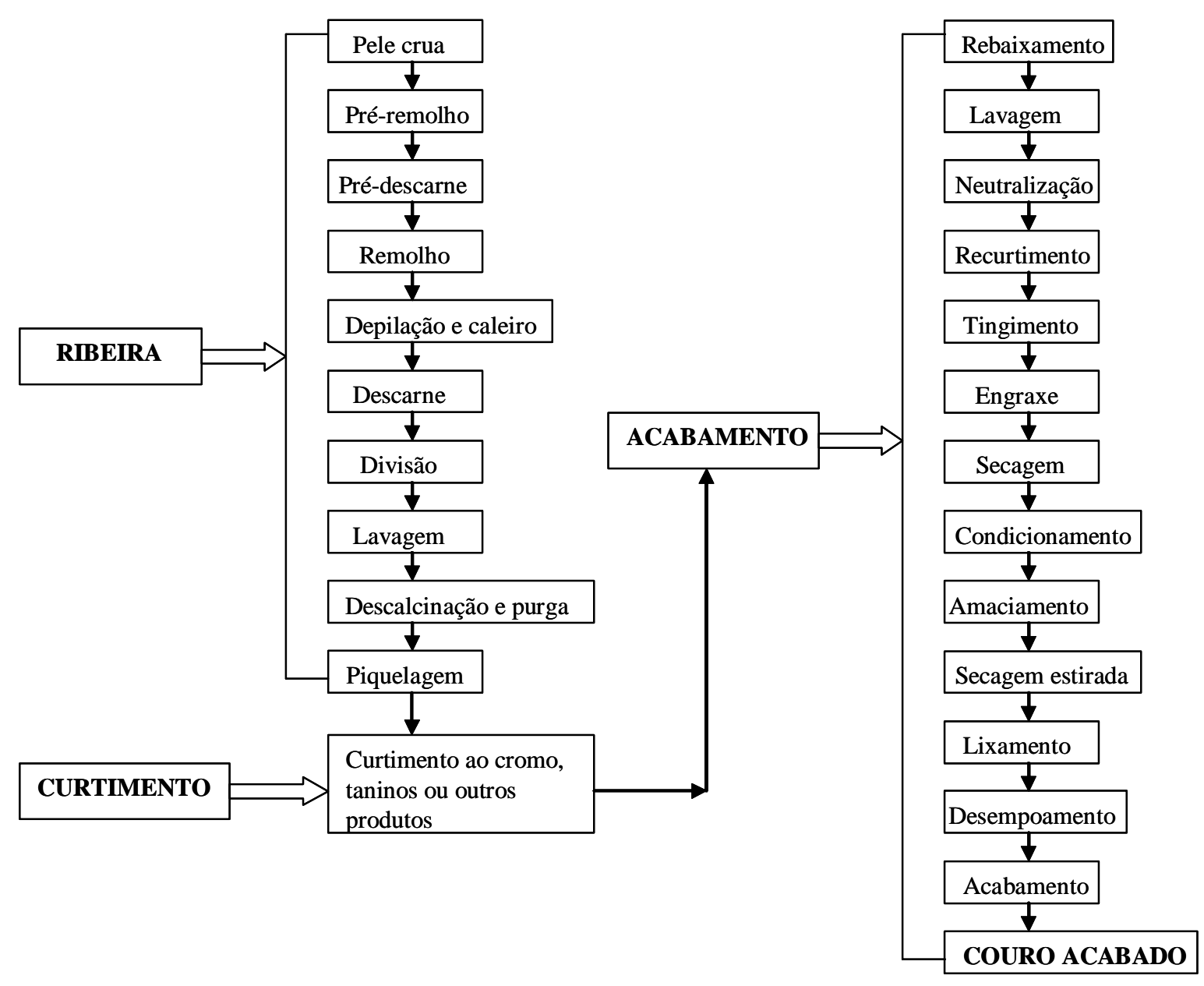

Fonte: adaptado de HOINACK \& MOREIRA (1994)

Figura 2 - Operações e processos da transformação da pele crua em couro curtido.

\section{- Ribeira}

A ribeira tem como finalidade limpeza e remoção de pêlos, gorduras, carnes e alguns materiais interfibrilares da pele, com vistas à obtenção de peles ricas em fibras de colágeno para serem transformadas em couro acabado. Na depilação e caleiro da pele, a epiderme é retirada através de processos químicos nos quais são utilizados o sulfeto de sódio e o hidróxido de cálcio. Na etapa seguinte, ou seja, no descarne, é retirada a hipoderme, além do 
material interfibrilar ser removido da derme. Dessa forma, no final dos processos e operações iniciais de transformação da pele em couro, a pele apresenta apenas a derme, camada intermediária da pele que será transformada em couro nas etapas subseqüentes (HOINACK \& MOREIRA, 1994).

\section{- Curtimento}

O curtimento consiste na conversão do colágeno presente na pele em uma substância imputrescível, o couro. Os reagentes mais utilizados nesse processo são taninos vegetais e artificiais, sais de alumínio e o cromo.

Atualmente, a maior parte dos couros é curtida ao cromo; os principais agentes são sais ou óxidos desse elemento. Realizado em fulões, durante 4 a 24 horas, o curtimento ao cromo torna o couro mais resistente à passagem de água, mais elástico e flexível, além de facilitar o tingimento. Normalmente, emprega-se no processo 8 a $12 \%$ de sal de cromo curtente (complexos hidratados de sulfato de cromo trivalente basificado com 22 a $25 \%$ de $\mathrm{Cr}_{2} \mathrm{O}_{3}$ ), mais $1 \%$ de bicarbonato de sódio (agente alcalinizante) para ajuste do $\mathrm{pH}, 0,1$ a 0,5\% de formiato ou ftalato de sódio ou sais de ácidos dicarboxílicos, e, eventualmente, 0,1\% de fungicida, caso o produto seja armazenado ou transportado em estado úmido (JOST, 1990).

Segundo Braile (1993), a principal vantagem do curtimento ao cromo reside na abreviação do tempo de curtimento, reduzido a menos de um dia, além de produzir um couro com maior resistência ao calor e ao desgaste.

\section{- Acabamento}

Esta etapa tem como finalidade homogeneizar, amaciar e corrigir pequenos defeitos na superfície do couro. É nesta etapa, durante a operação de rebaixamento, que a serragem de couro do tipo wet blue é formada. A Figura 3 mostra a rebaixadeira e a serragem de couro do tipo wet blue originada no processo de rebaixamento do couro no curtume. 


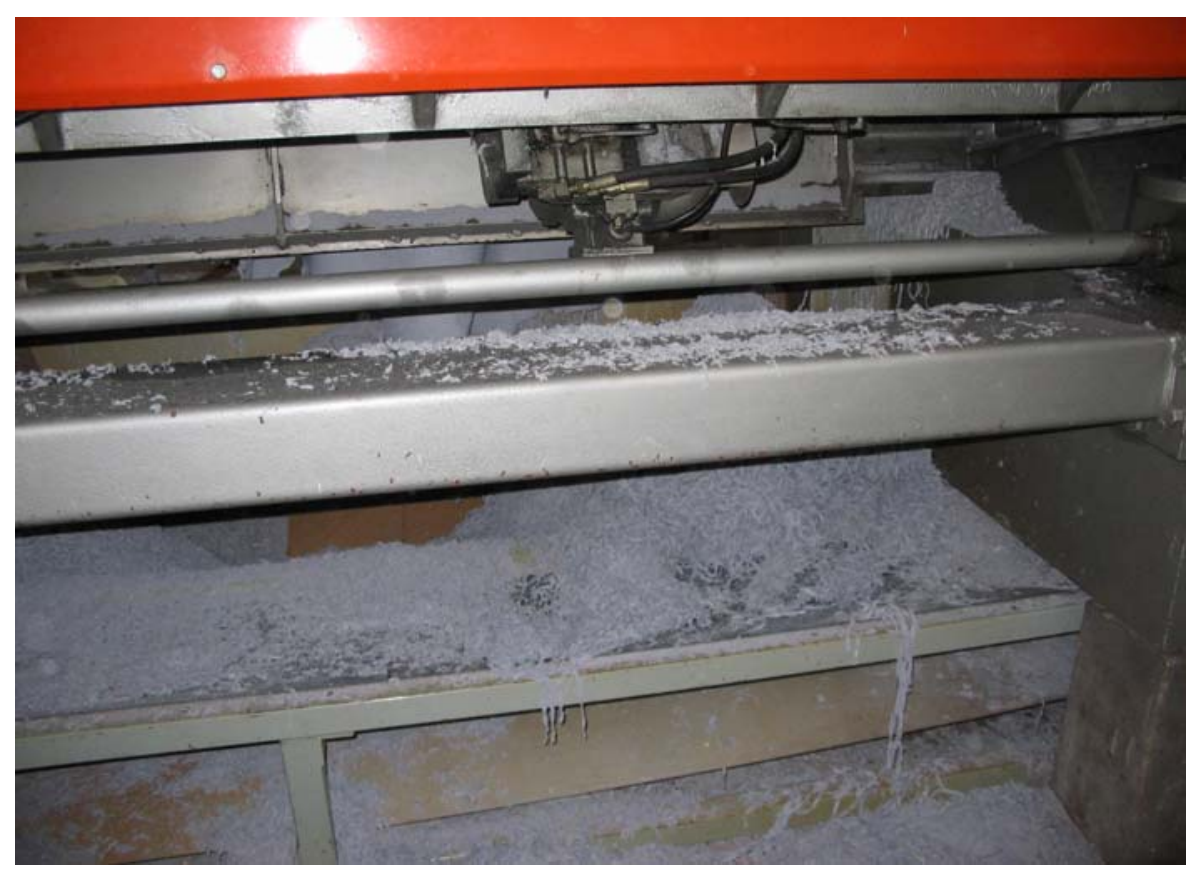

Figura 3 - Vista geral da rebaixadeira e da serragem de couro

\subsubsection{Principais sólidos gerados em curtume}

Os principais resíduos sólidos gerados em curtume podem ser divididos em três grupos:

a) resíduos não curtidos (aparas caleadas e não caleadas e carnaças);

b) resíduos curtidos (aparas de couro curtido, serragem de couro, pó da lixadeira)

c) lodo de estação de tratamento de esgoto.

Um maior enfoque será dado à serragem de couro, devido à sua utilização nesse trabalho como meio suporte de filtros percoladores.

Esse resíduo é resultado da operação de rebaixe e é constituído principalmente de fibras curtidas e produtos químicos. A produção deste resíduo é grande, variando de 150 a 180kg por tonelada de pele processada. Apresenta teores de umidade entre 20 e $45 \%$ e a sua densidade é da ordem de $0,35 \mathrm{~g} / \mathrm{cm}^{3}$. A concentração média do cromo trivalente encontrada nestes resíduos é de 8g/kg em base seca (CETESB, 1980). Recentemente, alguns autores caracterizaram essa serragem e os resultados podem ser descritos na Tabela 2. 
Tabela 2 - Parâmetros determinados para caracterização da serragem de couro bruta do tipo wet blue

\begin{tabular}{|c|c|c|c|}
\hline Parâmetros & SOUZA (1999) ${ }^{(1)}$ & MOREIRA (2003) ${ }^{(2)}$ & SUASSUNA (2004) \\
\hline Umidade (\%) & 27,00 & 30,00 & 25,00 \\
\hline Nitrogênio Total (mg/kg) & - & - & 151,00 \\
\hline pH em água & 3,66 & 3,20 & 3,22 \\
\hline $\mathrm{DQO}\left(\mathrm{mgO}_{2} / \mathrm{kg}\right)$ & $9,6 \times 10^{5}$ & $5,8 \times 10^{5}$ & $1,19 \times 10^{6}$ \\
\hline Cromo Total (mg/kg) & 32500 & 31000 & 26400 \\
\hline
\end{tabular}

(1) : base seca $-60^{\circ} \mathrm{C}$ sob ventilação por $24 \mathrm{~h}$

(2) : base seca $-105^{\circ} \mathrm{C}$ por $24 \mathrm{~h}$ em estufa

\subsubsection{Alguns empregos para a serragem de couro}

A serragem resultante do beneficiamento do couro é o resíduo que mais acarreta problemas para os curtumes, pois ocupa grandes volumes e acumula-se diariamente nos cantos das indústrias, devido à dificuldade de se encontrar um local para depositá-la. Acaba assim, sendo disposta inadequadamente, acarretando diversos danos ao meio ambiente, por conter produtos químicos tóxicos.

Atualmente, pesquisadores têm estudado outras formas de tratamento e destinos para esses resíduos. Bidoni (1995) estudou a vermicompostagem de resíduos sólidos de curtume (lodo primário, lodo ao cromo, raspas, aparas e serragem ao cromo), utilizando o lixo orgânico urbano como substrato para as minhocas e chegou a resultados bastante satisfatórios, no que se refere à atenuação do cromo.

Brito et al (2002) obtiveram eficiência de atenuação de cromo total de até 60,2\%, após o processo de codisposição de resíduos sólidos do beneficiamento do couro (serragem de couro e pó da lixadeira) e resíduos sólidos de feiras livres.

A serragem também pode ser utilizada na fabricação de palmilhas e solas de sapatos e na construção de paredes divisórias. Além desses usos, Souza (1999), Moreira (2003) e Suassuna (2004) concluíram que a utilização da serragem de couro como meio suporte em filtros percoladores é também uma boa alternativa, já que após serem utilizadas nos filtros, passaram a ser classificadas como resíduos classe II - não inertes. 


\subsection{CROMO}

\subsubsection{Considerações gerais}

Os metais pesados constituem-se hoje num dos mais importantes micropoluentes para os sistemas de tratamento de águas residuárias, especialmente por sua capacidade tóxico/inibidora (POVINELLI, 1987). Dentre esses metais, o cromo tem recebido atenção especial devido à sua ampla utilização nas mais diferentes indústrias, como na produção do aço, na preservação da madeira e no curtimento do couro.

Cromo (Cr) é o nome dado ao metal de transição de número 24, massa atômica 51,996, de alto ponto de fusão $\left(1830^{\circ} \mathrm{C}\right)$ e resistente à corrosão. Em seus compostos, apresenta estados de oxidação desde +1 até +6, mas os mais comuns são os estados +3 e +6 (RUSSELL, 1994).

Cromo III é um elemento importante no metabolismo da glicose, lipídio e proteína nos mamíferos; por outro lado, em elevada concentração pode ser perigoso para a fauna e flora. Segundo Nussbaum (2001), a dose recomendada para adultos varia entre 0,05 e 0,20 mg/dia.

No seu estado de oxidação +6 é altamente tóxico, mutagênico e cancerígeno aos homens e animais, por sua capacidade de transpor as membranas celulares e apresentar forte capacidade oxidante (NUSSBAUM, 2001). O efeito tóxico do cromo hexavalente está em torno de 100 a 1000 vezes maior que o do cromo trivalente (GUNSÉ et al., 1992).

\subsubsection{Presença de cromo VI nos produtos finais dos curtumes}

Os curtumes utilizam o cromo na forma trivalente para o curtimento, portanto deparam-se com o problema da presença de cromo hexavalente em seus produtos finais. Segundo estudos realizados por Babu et al (2004), a utilização de produtos auxiliares para acabamento, como neutralizadores químicos, agentes para recurtimento, tinturas, entre outros, possibilita a conversão de uma considerável quantidade de cromo III em cromo VI sob condições favoráveis de $\mathrm{pH}$, devido à presença de um grupo funcional com alto poder oxidante. 


\subsubsection{Toxicidade do cromo sobre os microrganismos envolvidos nos processos biológicos}

A toxicidade está principalmente relacionada com a concentração do agente tóxico, podendo servir como agente estimulante a baixas concentrações e ser fortemente inibidor para concentrações mais elevadas. Devido à complexidade das reações que ocorrem no interior do reator, outros fatores também interferem na toxicidade como a solubilidade do composto, o tempo de exposição e efeitos sinérgicos (toxicidade aumentada pela presença de outra substância) e antagônicos (toxicidade diminuída pela presença de outra substância).

Jianlong et al (2003) estudaram o efeito do cromo no crescimento da Saccharomyces cerevisiae e verificaram uma fase lag mais longa quando comparada ao seu crescimento na ausência de cromo. Para a concentração de $15 \mu \mathrm{M}$, houve inibição de $30 \%$ em relação ao controle no crescimento bacteriano e para $5 \mu \mathrm{M}$, não houve efeito significativo sobre essa população.

Com relação à influência do cromo nos processos de nitrificação, observou-se que 0,25mg/l inibiu a nitrificação em pequena quantidade, porém, concentrações de 2 a $5 \mathrm{mg} / \mathrm{l}$ inibiu completamente esse processo (EPA ${ }^{3}, 1977$ apud POVINELLI, 1987). Segundo Eckenfelder (1989), uma forma de atenuar esse efeito é aumentar o tempo de retenção celular.

3 EPA (1977) - Federal Guidelines - State and Local Pre-treatment Programs Construction Grants Programs Information I, II and III. Washington, D.C., U.S. EPA-430/976-017a. Vol. I, Section E, E-1 a E-26. 


\section{MATERIAL E MÉTODOS}

\subsection{PRIMEIRA FASE - PREPARAÇÃO DA SERRAGEM DE COURO}

A serragem de couro (Figura 4) utilizada no experimento foi coletada no Curtume BMZ Couros Ltda., localizado na cidade de Franca/SP.

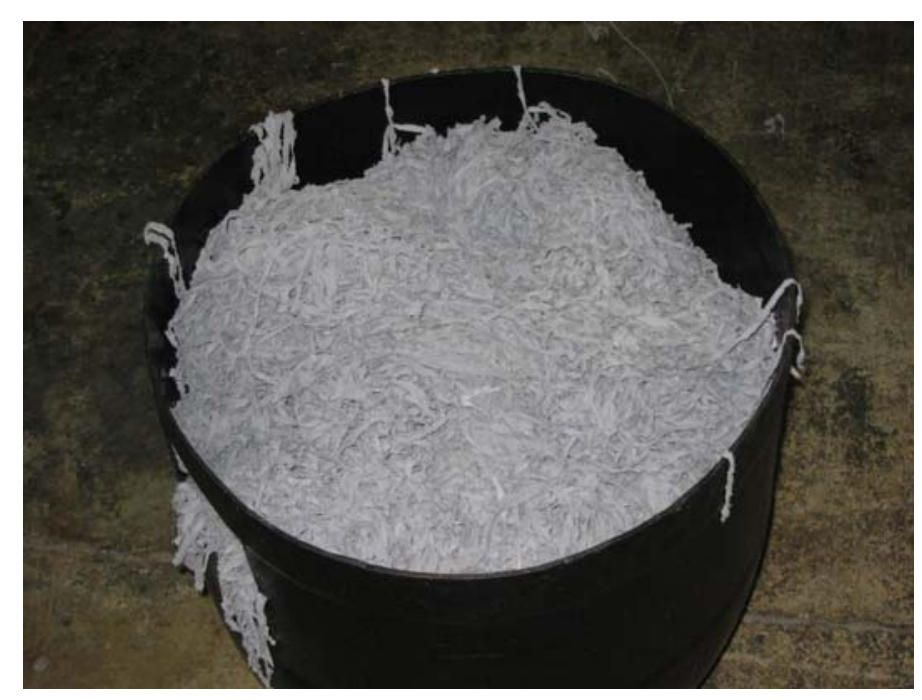

Figura 4 - Serragem de couro do tipo wet blue utilizada como meio suporte

$\mathrm{Na}$ preparação da serragem de couro foram realizadas as etapas de peneiramento e lavagem. No peneiramento foi utilizada uma peneira de 9,5mm e o material foi peneirado até que somente a serragem de maior granulometria ficasse retida na peneira, a fim de ser utilizada no preenchimento dos filtros e evitando assim, que o material de menor granulometria viesse a colmatá-los.

Devido ao alto teor de cromo presente na serragem de couro tornou-se necessária a lavagem desse material, com a finalidade de atingir concentrações de cromo no efluente inferiores a 0,5mg/L, limite estabelecido pela Resolução CONAMA 357/05. Dessa forma, foram realizadas quatro lavagens alcalinas com a adição de hidróxido de cálcio e com recirculação do efluente, como sugerido por Moreira (2003).

Em cada lavagem foi utilizado um tambor de 50L preenchido com uma camada de brita no 
fundo de aproximadamente $8 \mathrm{~cm}$, com peso total de $12,5 \mathrm{~kg}$ de seixos e granulometria variando entre 2,4 e 25,4mm. Sobre a camada de brita foram colocados $3 \mathrm{~kg}$ de serragem de couro peneirada. Foram adicionados 20L de água e $10 \mathrm{~g}$ de hidróxido de cálcio. A vazão de recirculação foi de 20L/h. Foram coletadas amostras nos intervalos de tempos de 2, 5, 10, 20, 30, 60, 120 e 180 minutos.

\subsection{SEGUNDA FASE - APLICAÇÃO DO EFLUENTE NOS FILTROS PERCOLADORES}

Após a preparação do material suporte, iniciou-se a aplicação do efluente nos filtros percoladores por 112 dias. O filtro F4 foi operado até o $85^{\circ}$ (octagésimo quinto dia), quando apresentou problema de colmatação do leito.

O sistema experimental foi composto por quatro filtros percoladores operados como unidades independentes e aeradas para pós-tratamento de esgoto sanitário tratado em reator anaeróbio compartimentado.

\subsubsection{Reator compartimentado}

O reator anaeróbio compartimentado possui quatro compartimentos verticais, interligados por tubulações que distribuem o líquido de uma câmara para outra e separados por chicanas, conforme mostrado na Figura 5. O volume total do reator é de $11 \mathrm{~m}^{3}$, com quatro câmaras funcionando como reatores em série. A quarta câmara possui um decantador de placas paralelas e uma saída de fundo para descarte de lodo (POVINELLI, 1999). 


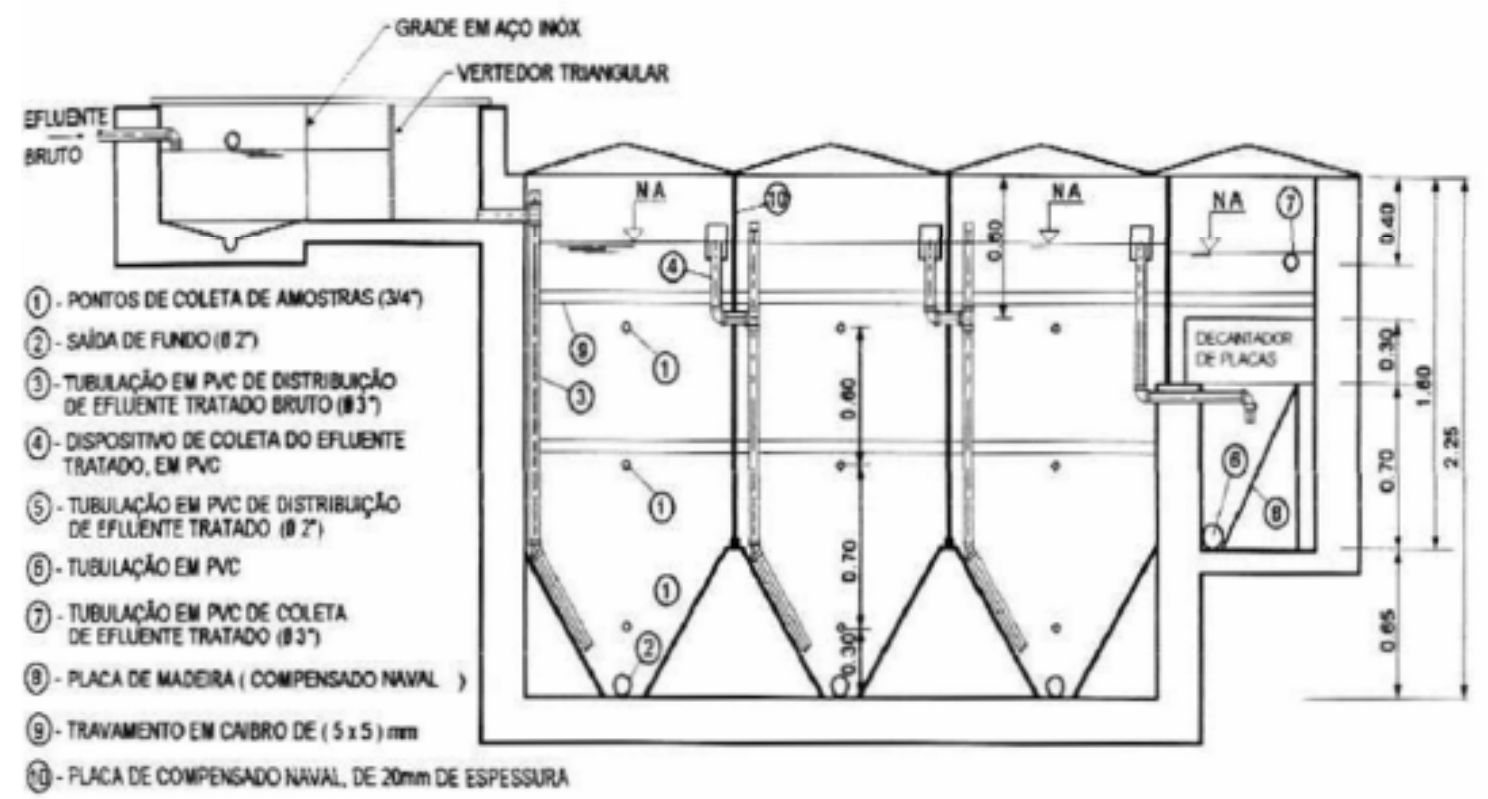

Fonte: POVINELLI (1999)

Figura 5 - Representação esquemática do reator anaeróbio compartimentado

O esgoto sanitário afluente ao reator anaeróbio compartimentado provém da rede pública coletora de esgoto de um bairro da cidade de São Carlos. A Tabela 3 apresenta alguns parâmetros físicos e químicos desse esgoto.

Tabela 3 - Parâmetros físicos, químicos e biológicos do esgoto afluente do reator compartimentado

\begin{tabular}{ccc}
\hline Parâmetros & \multicolumn{2}{c}{ FONTES } \\
& POVINELLI (1999) & RÊGO (2002) \\
\hline pH & 6,8 & 7,1 a 8,0 \\
Alcalinidade Total (mg CaCO $/ \mathrm{L})$ & 115 & $165 \pm 25$ \\
DQO Total (mg/L) & 490 & $232 \pm 115$ \\
DQO Filtrada (mg/L) & 170 & $145 \pm 83$ \\
DBO 5 Total (mg/L) $_{\text {Sólidos Totais (mg/L) }}$ & - & - \\
Sólidos Suspensos Totais (mg/L) & 654 & $313 \pm 56$ \\
Sólidos Suspensos Voláteis (mg/L) & 203 & $85 \pm 35$ \\
NTK (mg/L) & 174 & $60 \pm 29$ \\
\hline
\end{tabular}

\subsubsection{Filtros percoladores}

Os filtros percoladores (Figura 6) utilizados no experimento foram confeccionados em 
PVC e apresentam as seguintes características: h (altura)- 100cm; d (diâmetro) - 20 cm e V (volume) - 31,4L e foram disponíveis no Laboratório de Tratamento de Resíduos Orgânicos (LTR), localizado no Departamento de Hidráulica e Saneamento da Escola de Engenharia de São Carlos - Universidade de São Paulo.

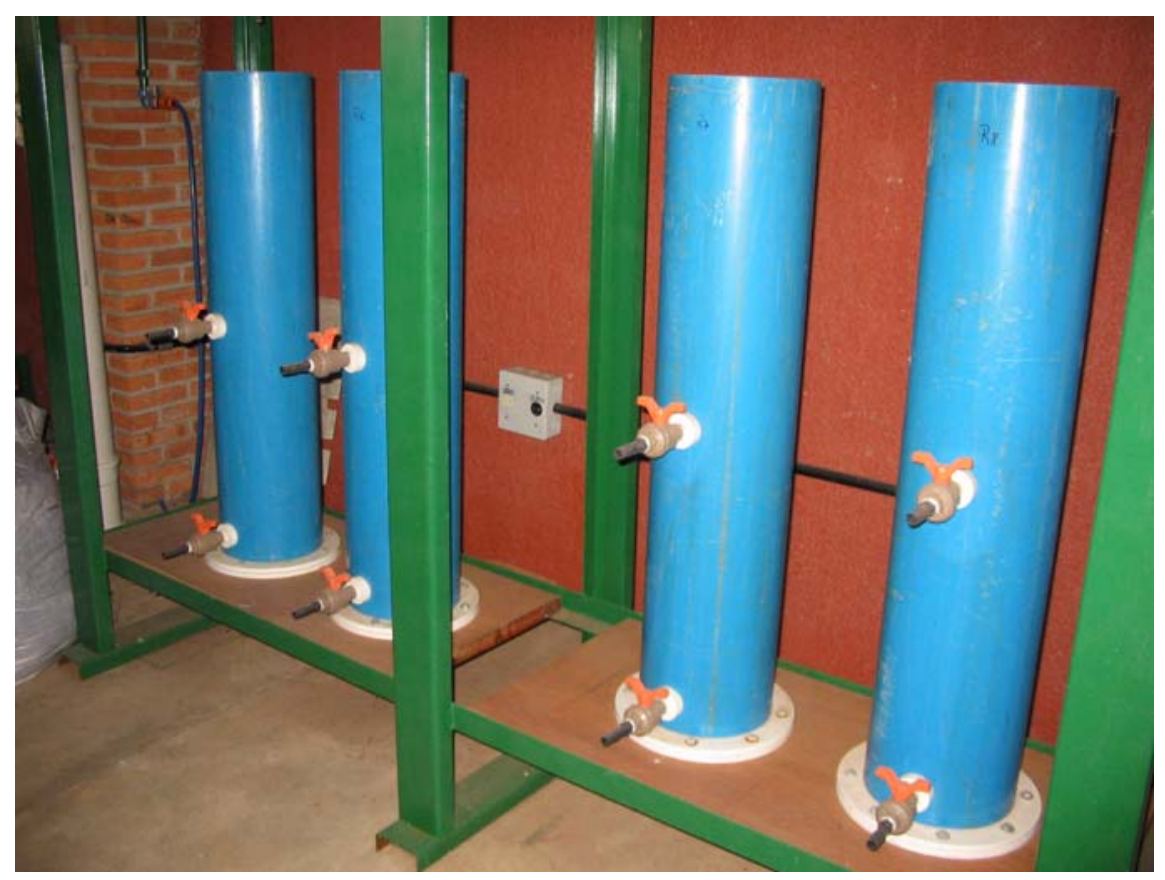

Figura 6 - Filtros percoladores utilizados para o pós-tratamento de efluente de reator anaeróbio compartimentado

\subsubsection{Características e operação dos filtros}

O filtro F1 foi preenchido com brita (granulometria entre 9,5mm e 12,5mm) até uma altura de $63 \mathrm{~cm}$. Os demais F2, F3 e F4 foram preenchidos por uma dupla camada de brita e serragem de couro preparada na primeira fase com alturas de 3 e $60 \mathrm{~cm}$ respectivamente. Foram utilizados em cada filtro aproximadamente $2,0 \mathrm{~kg}$ de brita e $4,0 \mathrm{~kg}$ de serragem. A camada de brita teve a função de evitar a colmatação do filtro.

Os filtros foram operados com diferentes taxas de aplicação hidráulica, com F1 e F2 operados com taxa de aplicação hidráulica de $1,9 \mathrm{~m}^{3} / \mathrm{m}^{2}$.dia, a mesma utilizada por Suassuna (2003), e que enquadram-se dentro da faixa utilizada para filtros de baixa taxa, segundo os 
limites estabelecidos por Metcalf e Eddy (2003). Os filtros F3 e F4 apresentaram taxa de aplicação hidráulica de 4 e $6 \mathrm{~m}^{3} / \mathrm{m}^{2}$.dia e enquadram-se no limite superior de filtro de baixa taxa e taxa intermediária respectivamente.

A Tabela 4 resume as características e as condições operacionais dos filtros percoladores.

Tabela 4 - Características e condições operacionais dos filtros percoladores

\begin{tabular}{cccc}
\hline $\begin{array}{c}\text { Filtro } \\
\text { percolador }\end{array}$ & Meio suporte & $\begin{array}{c}\text { Taxa de aplicação } \\
\left(\mathbf{m}^{\mathbf{3}} / \mathbf{m}^{\mathbf{2}} \mathbf{. d i a}\right)\end{array}$ & $\begin{array}{c}\text { Vazão } \\
\mathbf{L} / \mathbf{h}\end{array}$ \\
\hline F1 & brita & 1,91 & 2,50 \\
F2 & brita e serragem de couro & 1,91 & 2,50 \\
F3 & brita e serragem de couro & 4,00 & 5,24 \\
F4 & brita e serragem de couro & 6,00 & 7,85 \\
\hline
\end{tabular}

Cada filtro recebeu aeração através de dois difusores de ar colocados no interior do leito filtrante e ligados a aeradores de aquário através de mangueiras.

Com a finalidade de proporcionar distribuição uniforme do esgoto afluente, cada filtro foi adaptado com um sistema de distribuição composto de duas canaletas cruzadas, confeccionadas em PVC, perfuradas e colocadas nas paredes dos filtros, conforme mostra a Figura 7.

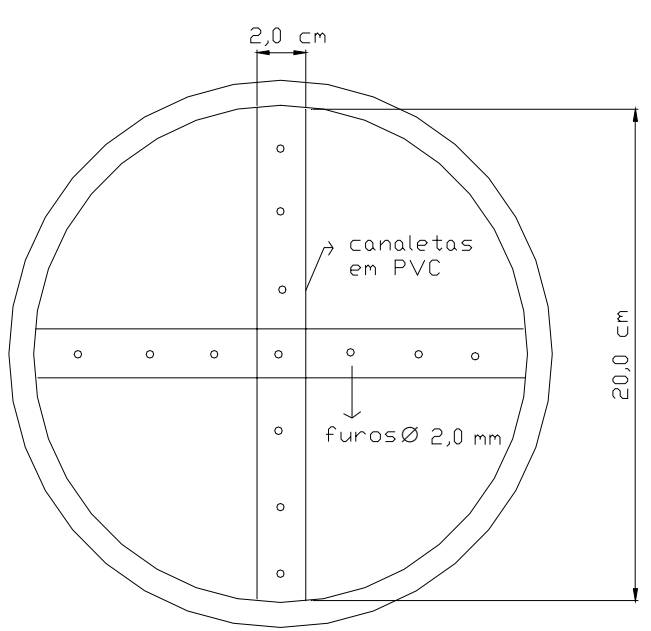

Figura 7 - Vista Superior do sistema de distribuição do esgoto afluente aos filtros percoladores 
Esses filtros receberam o esgoto efluente do reator anaeróbio compartimentado existente nas instalações do Laboratório de Tratamento de Resíduos Orgânicos (LTR). Para manter a vazão constante, o efluente do reator compartimentado foi armazenado numa caixa de 150L e dessa bombeado para o sistema através de quatro bombas dosadoras, sendo uma para cada filtro.

Na Figura 8 está apresentado o fluxograma do sistema.

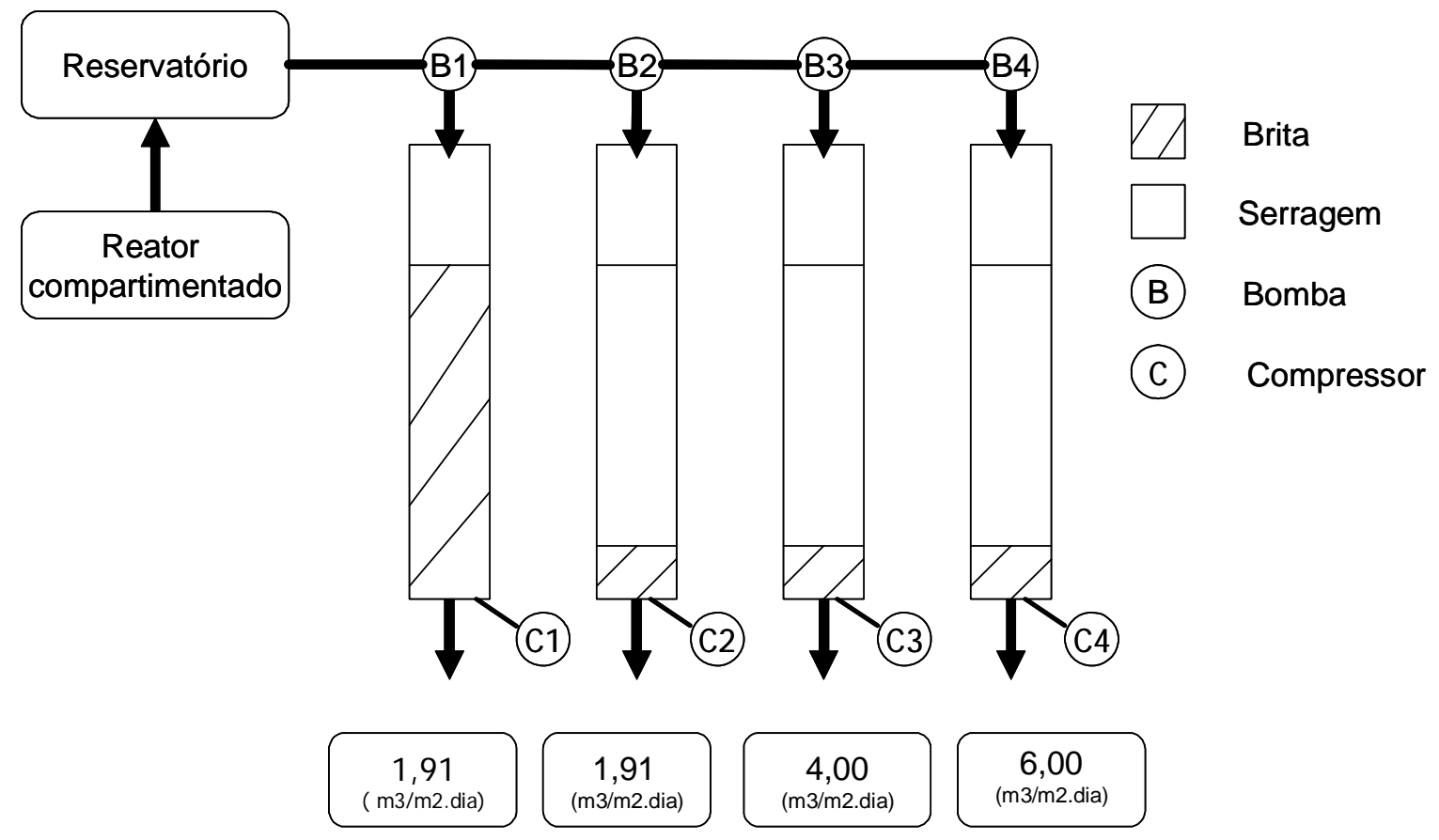

Figura 8 - Representação esquemática da instalação experimental

\subsubsection{Monitoramento}

O sistema foi monitorado no afluente dos filtros (efluente do reator anaeróbio compartimentado) e efluente dos quatro filtros percoladores. As análises, assim como as freqüências e os métodos a serem utilizados, encontram-se na Tabela 5.

Além dessas análises, também foi realizada microscopia óptica de contraste de fase e fluorescência para acompanhar o desenvolvimento da biomassa. As amostras foram retiradas dos filtros F1 (brita) e F2 (serragem de couro), a 10cm da superfície do leito, no $6^{\circ}$ (sexto), 
$41^{\circ}$ (quadragésimo primeiro) e $84^{\circ}$ (octogésimo quarto) dia de operação.

Tabela 5 - Análises e freqüências dos principais parâmetros monitorados durante os experimentos

\begin{tabular}{cccc}
\hline Parâmetro & Unidade & Frequência & Método $*$ \\
\hline $\mathrm{pH}$ & - & 2 x por semana & Potenciométrico \\
Alcalinidade & $\mathrm{mg} \mathrm{CaCO}_{3} / \mathrm{L}$ & 2 x por semana & Titulométrico \\
Turbidez & $\mathrm{UNT}$ & Semanal & Espectrofotometria \\
Nitrogênio total & $\mathrm{mg} / \mathrm{L}$ & Semanal & Macro-Kjeldahl \\
Nitrogênio amoniacal & $\mathrm{mg} / \mathrm{L}$ & Semanal & Macro-Kjeldahl \\
Nitrito & $\mathrm{mg} / \mathrm{L}$ & Semanal & Espectofotométrico \\
Nitrato & $\mathrm{mg} / \mathrm{L}$ & Semanal & Espectofotométrico \\
Sólidos totais & $\mathrm{mg} / \mathrm{L}$ & Semanal & Gravimétrico \\
Sólidos suspensos & $\mathrm{mg} / \mathrm{L}$ & Semanal & Gravimétrico \\
DQO (total e filtrada) & $\mathrm{mg} / \mathrm{L}$ & Semanal & Refluxo fechado \\
Metais & $\mathrm{mg} / \mathrm{L}$ & Semanal & Absorção atômica \\
DBO ${ }_{5}$ total & $\mathrm{mg} / \mathrm{L}$ & Quinzenal & Oxímetro \\
Coliformes (totais e fecais) & $\mathrm{NMP} / 100 \mathrm{ml}$ & Quinzenal & Membrana filtrante \\
\hline
\end{tabular}

* Análises executadas de acordo com APHA (1998) 


\section{RESULTADOS E DISCUSSÃO}

\subsection{PRIMEIRA FASE - PREPARAÇÃO DA SERRAGEM DE COURO}

Devido ao alto teor de cromo presente na serragem de couro, tornou-se necessário a lavagem desse material. A Tabela 6 apresenta os resultados referentes às quatro lavagens (L1, L2, L3 e L4) da serragem em solução alcalina. As concentrações de cromo no efluente em todas as lavagens foram inferiores a 0,5mg/L após 30 minutos de operação. No início, as concentrações foram mais elevadas e diminuíram ao longo do tempo à medida que o cromo era precipitado.

O cromo precipitado foi recolhido e encaminhado para o setor de coleta de resíduos perigosos da universidade.

Tabela 6 - Parâmetros determinados para a lavagem da serragem de couro em solução alcalina

\begin{tabular}{|c|c|c|c|c|c|c|c|c|}
\hline \multirow{3}{*}{$\begin{array}{c}\text { Tempo } \\
\text { (min) }\end{array}$} & \multicolumn{8}{|c|}{ Lavagens efetuadas } \\
\hline & \multicolumn{2}{|r|}{$\mathbf{L 1}$} & \multicolumn{2}{|r|}{$\mathbf{L 2}$} & \multicolumn{2}{|r|}{ L3 } & \multicolumn{2}{|r|}{ L4 } \\
\hline & pH & $\operatorname{Cr}(\mathrm{mg} / \mathrm{L})$ & pH & $\operatorname{Cr}(\mathrm{mg} / \mathrm{L})$ & pH & $\operatorname{Cr}(\mathrm{mg} / \mathrm{L})$ & pH & $\operatorname{Cr}(\mathrm{mg} / \mathrm{L})$ \\
\hline 0 & 9,78 & 2,06 & 10,21 & 3,57 & $\overline{11,06}$ & 4,29 & 11,67 & 0,75 \\
\hline 2 & 9,74 & 0,54 & 10,14 & 5,72 & 10,90 & 0,67 & 11,50 & 0,55 \\
\hline 5 & 9,33 & 0,37 & 9,90 & 1,34 & 10,10 & 0,61 & 10,95 & 0,36 \\
\hline 10 & 8,94 & 0,25 & 9,60 & 1,20 & 9,45 & 0,80 & 10,95 & 0,53 \\
\hline 20 & 8,74 & 0,34 & 9,37 & 0,47 & 9,16 & 0,70 & 9,78 & 1,25 \\
\hline 30 & 8,55 & 0,27 & 9,10 & 0,34 & 9,10 & 0,45 & 9,21 & 0,22 \\
\hline 60 & 8,28 & 0,32 & 8,84 & 0,45 & 8,66 & 0,20 & 8,64 & 0,47 \\
\hline 120 & 8,19 & 0,41 & 8,91 & 0,48 & 8,54 & 0,42 & 8,62 & 0,35 \\
\hline 180 & 8,16 & 0,38 & 9,05 & 0,42 & 8,49 & 0,40 & 8,65 & 0,00 \\
\hline
\end{tabular}

\subsection{SEGUNDA FASE - APLICAÇÃO DO EFLUENTE NOS FILTROS PERCOLADORES}

\subsection{1 $\mathrm{pH}$}

De acordo com a Tabela 5 (Anexo) e a Figura 9 observa-se que nos primeiros dias de 
operação, os efluentes dos filtros preenchidos com serragem de couro apresentaram valores de pH mais baixos em relação ao filtro preenchido com brita. Este fato ocorreu provavelmente devido à presença de alguns ácidos que são utilizados durante o processo de curtimento do couro e acabaram sendo carreados pelo esgoto. Após esse período, houve elevação do pH para valores próximos à neutralidade.

Perto do $50^{\circ}$ (qüinquagésimo) dia de operação, o filtro F3 passou a apresentar valores de pH abaixo de 6,0, provavelmente devido à ocorrência mais acentuada do processo de nitrificação nesse filtro.

A média dos valores do $\mathrm{pH}$ do esgoto afluente foi de 6,8, e para o esgoto efluente dos filtros F1, F2, F3 e F4 foram respectivamente7,0, 7,1, 6,1 e 7,1.

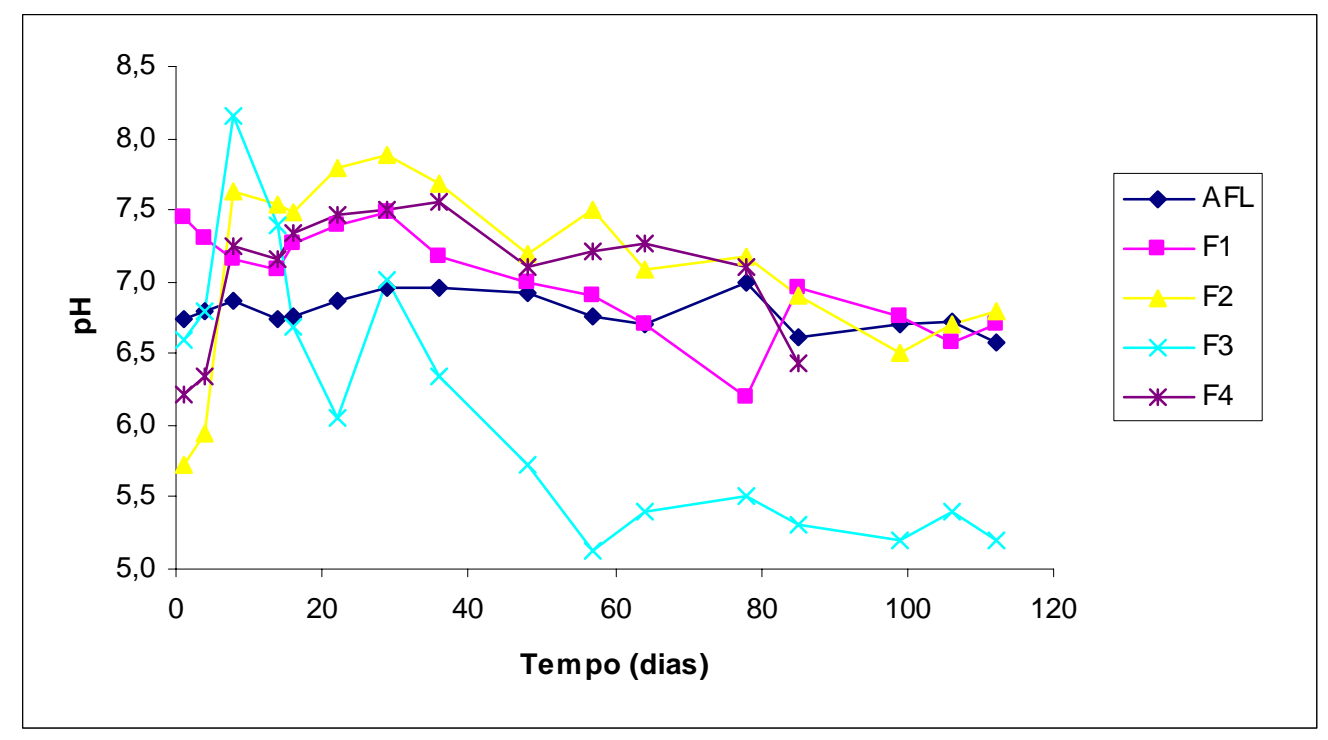

Figura 9 - Variação temporal do pH do esgoto sanitário afluente e efluente dos filtros percoladores

\subsubsection{Condutividade}

Os valores de condutividade estão representados na Tabela 7 (Anexo) e Figura 10 . Na primeira semana de operação, os filtros F2, F3 e F4 (preenchidos com serragem de couro) apresentaram valores de condutividade mais elevados, provavelmente devido à presença de 
sais, entre eles o cloreto de sódio, utilizado na conservação das peles. Depois disso, os valores decresceram devido à lixiviação desses sais e mantiveram-se flutuando entre 0,268 e $0,445 \mathrm{~ms} / \mathrm{cm}$.

O filtro F1 apresentou valores de condutividade variando entre $0,305 \mathrm{~ms} / \mathrm{cm}$ e $0,452 \mathrm{~ms} / \mathrm{cm}$.

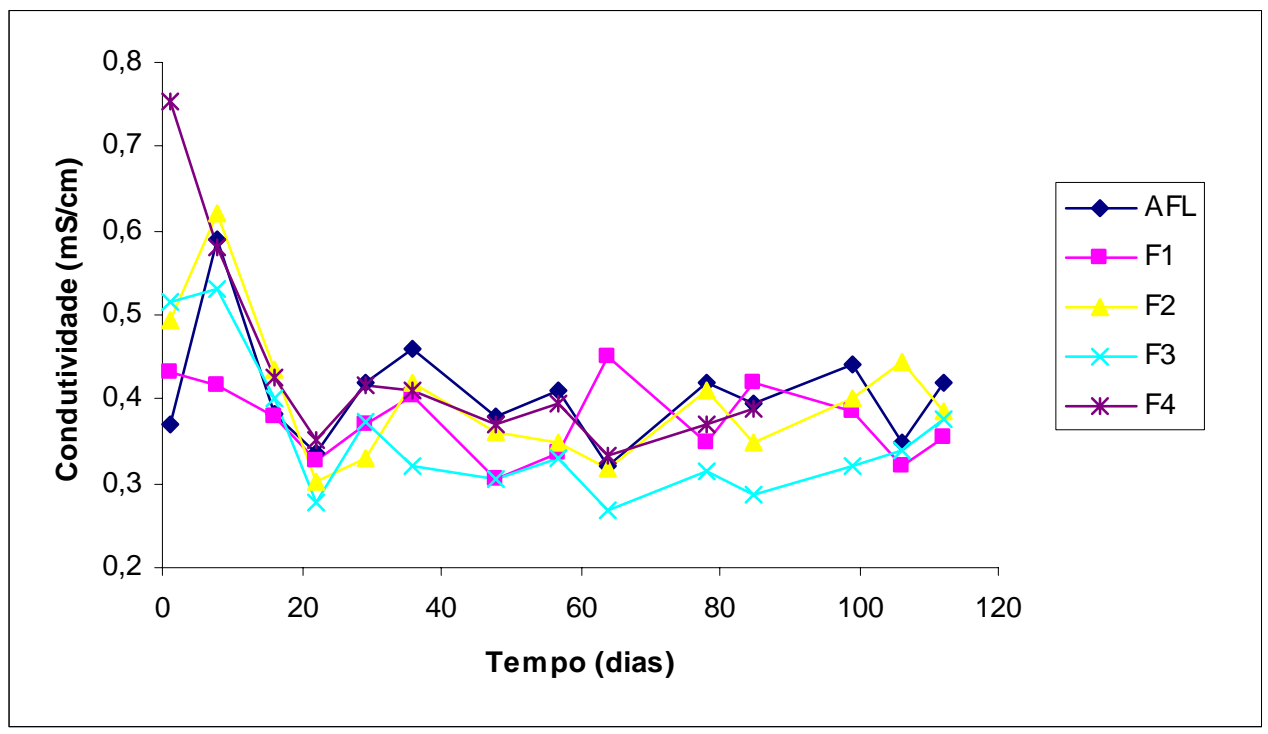

Figura 10 - Variação temporal da condutividade do esgoto sanitário afluente e efluente dos filtros percoladores

\subsubsection{Turbidez}

De acordo com as Tabelas 8 e A4 (Anexo) e a Figura 11, todos os filtros apresentaram redução significativa de turbidez em relação ao afluente.

O filtro F3 apresentou melhores resultados, com eficiência média de remoção de 86\%. Os filtros F1 e F2 apresentaram eficiências médias de 71\% e 73\%, respectivamente. O filtro F4, operado com a maior taxa de aplicação hidráulica, apresentou menores reduções nos valores de turbidez em relação ao afluente (47\%), provavelmente devido ao maior arraste de sólidos finos desprendidos da serragem e que contribuíram para elevação desses valores.

O valor médio de turbidez do esgoto afluente foi de 73UNT, enquanto que nos efluentes dos filtros F1, F2, F3 e F4 foram respectivamente 20UNT, 18UNT, 10UNT e 35UNT. 


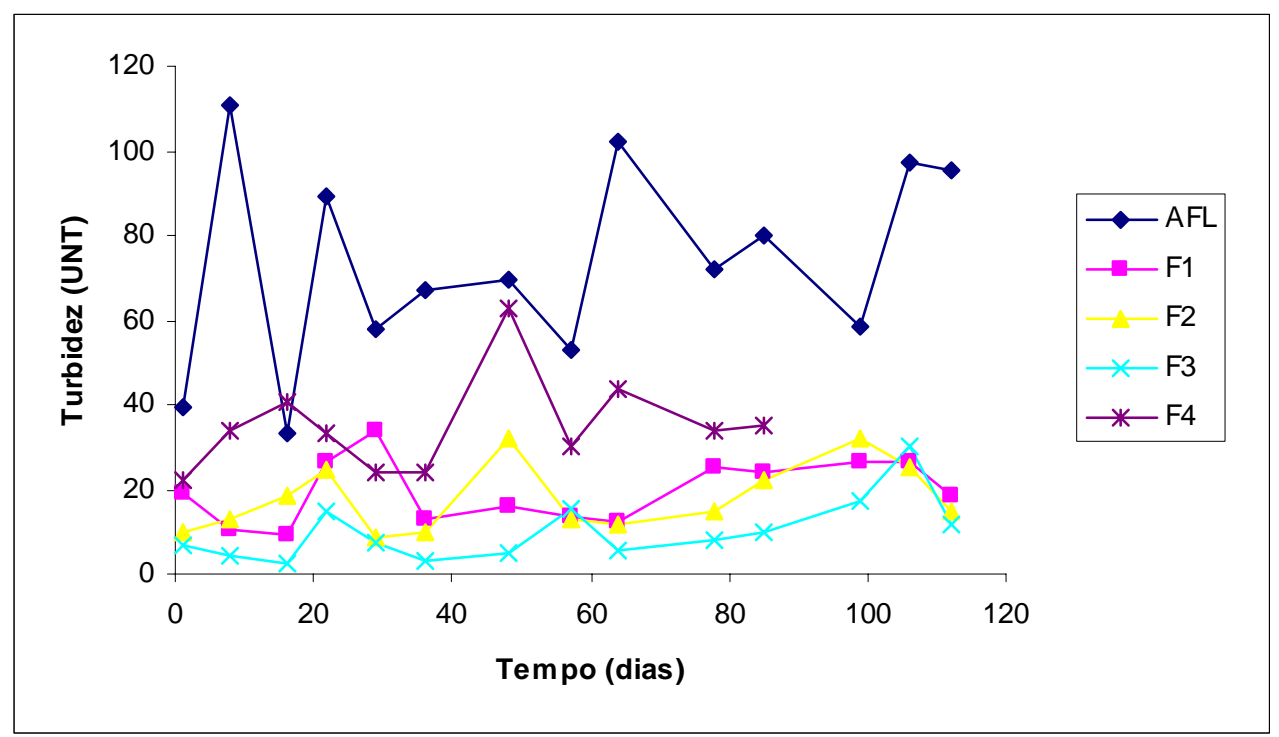

Figura 11 - Variação temporal de turbidez do esgoto sanitário afluente e efluente dos filtros percoladores

\subsubsection{Alcalinidade Total}

Na Tabela A 5 (Anexo) e na Figura 12 é possível observar que no primeiro dia de operação, os valores de alcalinidade total dos efluentes foram baixos nos filtros F2, F3 e F4 (4,1mgCaCO $3 / \mathrm{L}$ para $\mathrm{F} 2,17,9 \mathrm{mgCaCO}_{3} / \mathrm{L}$ para $\mathrm{F} 3$ e $9,4 \mathrm{mgCaCO}_{3} / \mathrm{L}$ para $\mathrm{F} 4$ ), influenciados pelos baixos valores de pH. O filtro F1, preenchido com brita, não apresentou baixo valor de alcalinidade $\left(127,7 \mathrm{mgCaCO}_{3} / \mathrm{L}\right)$.

No entanto, após uma semana, quando o pH dos efluentes se restabeleceu para valores acima de 7,0, a alcalinidade nesses filtros elevou-se. A partir da segunda semana, o filtro F3 já apresentava valores reduzidos quando comparados aos demais, atingindo valores próximos à zero no $57^{\circ}$ (qüinquagésimo sétimo) dia. Este fato se deve, provavelmente, à ocorrência do processo de nitrificação mais acentuado nesse filtro, uma vez que esta reação envolve o consumo de alcalinidade.

Nos filtros F1 e F2 também houve redução de alcalinidade, porém menos significativa. No filtro F4 a redução foi ainda menor, o que possivelmente evidencia a pouca ocorrência da 
nitrificação nesse filtro.

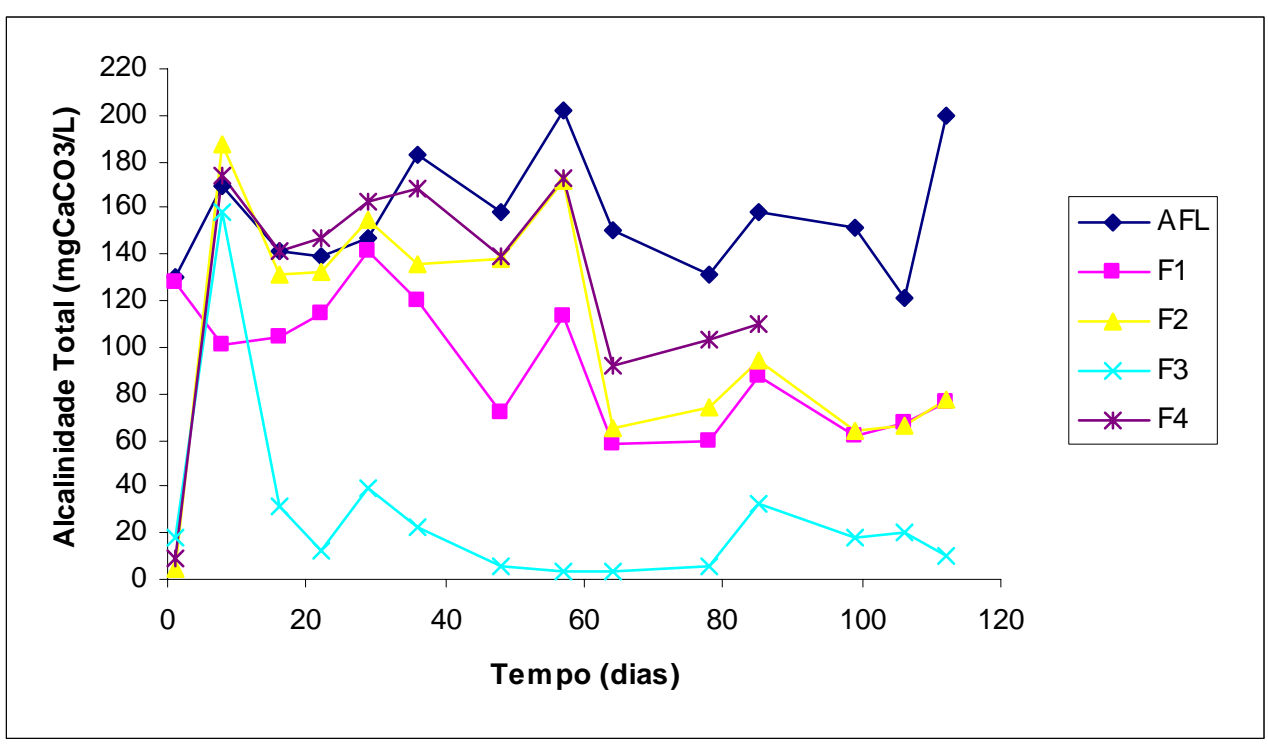

Figura 12 - Variação temporal da alcalinidade total do esgoto afluente e efluente dos filtros percoladores

\subsubsection{Nitrogênio Total Kjeldahl}

Nas Tabelas A 6 e A 7 (Anexo) estão expressas as concentrações de NTK do esgoto afluente e efluente e as eficiências de remoção dos filtros percoladores. A Figura 13 apresenta a variação temporal da concentração de NTK. Na primeira semana de operação, a concentração de nitrogênio total nos efluentes dos filtros foi alta, chegando a exceder a concentração do afluente em alguns filtros preenchidos com serragem de couro. Este fato se deve, provavelmente, aos sólidos finos desprendidos da serragem, que foram carreados pelo afluente e que contribuíram para elevar as concentrações de nitrogênio total, por serem estes constituídos principalmente de fibras de colágeno (compostos com alta concentração de nitrogênio).

A partir da segunda semana, o filtro F3 apresentou reduções significativas na concentração de nitrogênio total, atingindo eficiência média de 71\%. Nos filtros F1 e F2 também foi evidente a ocorrência do processo de nitrificação, porém menos significativa. O filtro F1 
apresentou eficiência média de remoção de 38\% e o filtro F2 de 41\%. No filtro F4 praticamente não houve remoção de Nitrogênio total e a eficiência foi de $15 \%$. A partir do $64^{\circ}$ (sexagésimo quarto) dia, o filtro F3 passou a apresentar eficiência de remoção de 100 \%. As eficiências médias dos outros filtros também foram maiores se considerarmos apenas esse período, sendo 50\% para F1, 73\% para F2 e 32\% para F4.

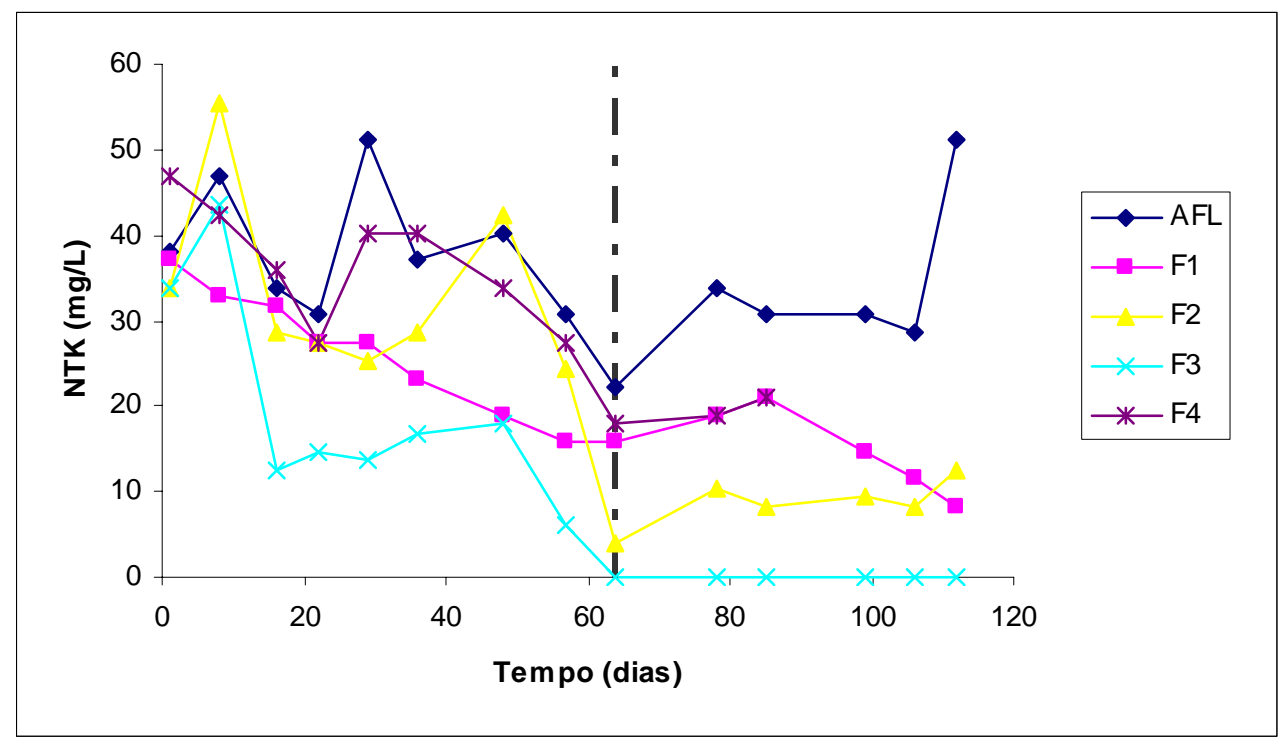

Figura 13 - Variação temporal da concentração de NTK do esgoto sanitário afluente e efluente dos filtros percoladores

\subsubsection{Nitrogênio Amoniacal}

As concentrações de nitrogênio amoniacal e as eficiências de remoção são mostradas nas Tabelas A 8 e A 9 (Anexo). A Figura 14 apresenta a variação temporal da concentração de nitrogênio amoniacal. Apresentam comportamento semelhante ao ocorrido com as concentrações de NTK. As eficiências médias de remoção dos filtros F1, F2, F3 e F4 (durante os 112 dias de operação) foram 36\%, 38\%, 71\% e 9\%, respectivamente.

O filtro F3 novamente apresentou melhores resultados e atingiu 100\% de eficiência de remoção, a partir do $64^{\circ}$ (sexagésimo quarto) dia. Os demais filtros também obtiveram maior eficiência média nesse período, sendo 48\% para F1, 79\% para F2 e 30\% para F4. 


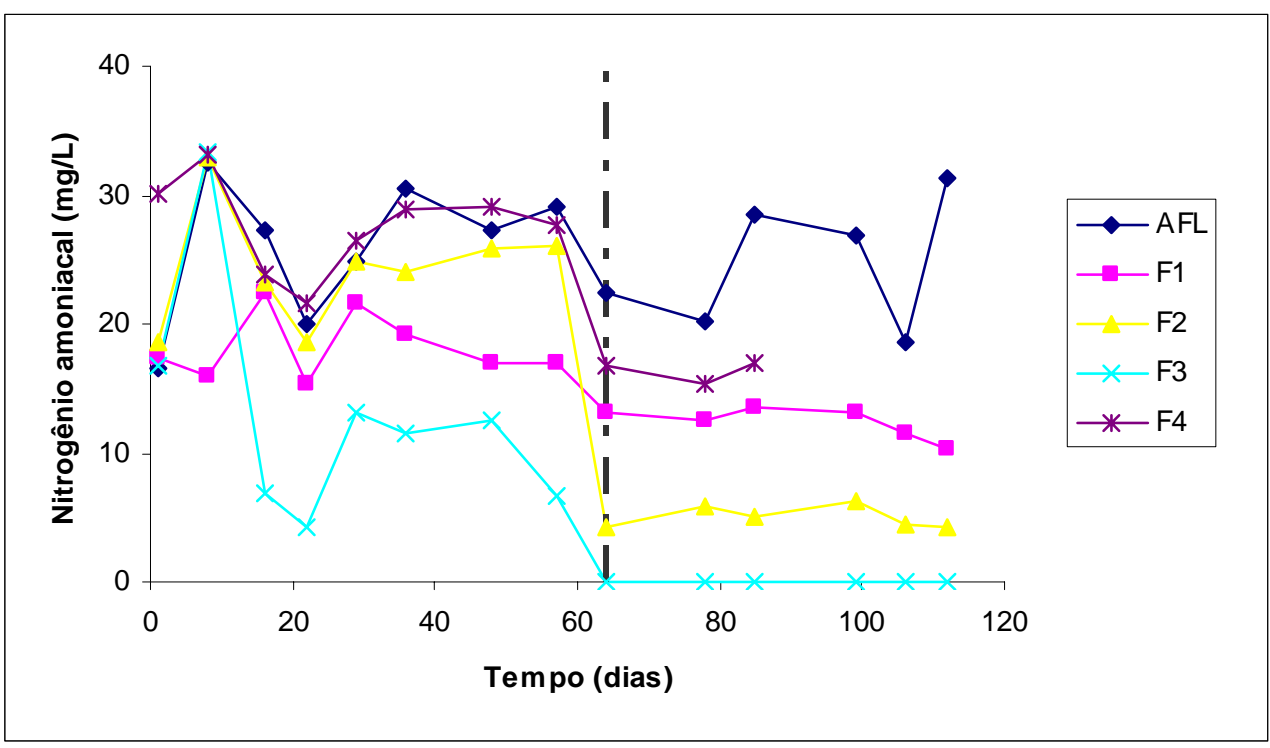

Figura 14 - Variação temporal da concentração de nitrogênio amoniacal do esgoto sanitário afluente e efluente dos filtros percoladores

\subsubsection{Nitrato}

Na Tabela A 10 (Anexo) estão expressas as concentrações de nitrato, representadas na Figura 15. As concentrações de nitrato nos filtros F1, F2 e F3 aumentaram ao longo do tempo com a estabilização do processo de nitrificação. O filtro F4 apresentou baixas concentrações de nitrato, o que mais uma vez evidencia que a nitrificação ocorreu em pequena proporção.

A partir do $64^{\circ}$ (sexagésimo quarto) dia, quando a nitrificação foi mais acentuada, as médias das concentrações dos efluentes dos filtros F1, F2, F3 e F4 foram 16,8mg/l, 18,6mg/l, 22,6mg/l e 4,1mg/l, respectivamente. 


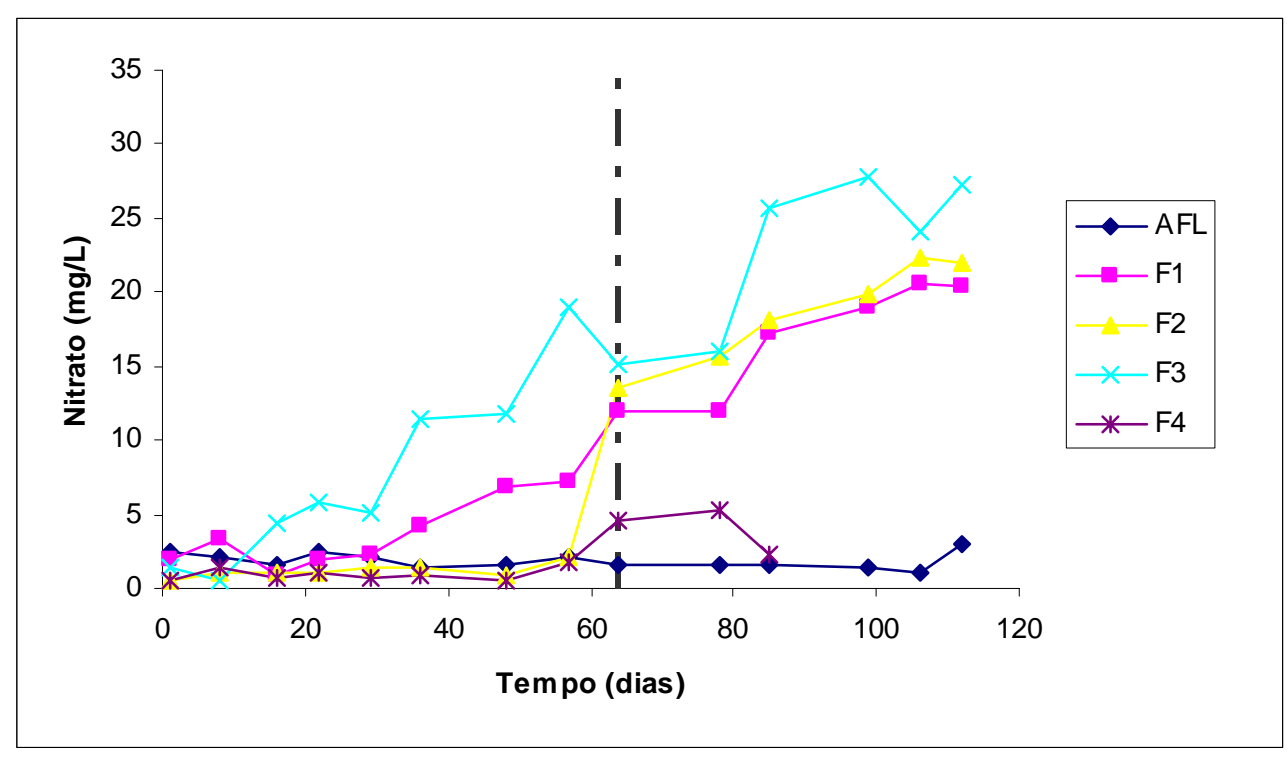

Figura 15 - Variação temporal da concentração de nitrato do esgoto sanitário afluente e efluente dos filtros percoladores

\subsubsection{Nitrito}

Na Tabela A 11 (Anexo) estão expressas as concentrações de nitrito, representadas na Figura 16.

Nota-se que os filtros apresentaram picos nas concentrações de nitrito, que podem ter sido provocados por deficiência na aeração, provocando déficit na concentração de oxigênio dissolvido e consequentemente diminuindo a atividade das bactérias responsáveis pela nitratação, mais sensíveis a baixas concentrações de O.D. 


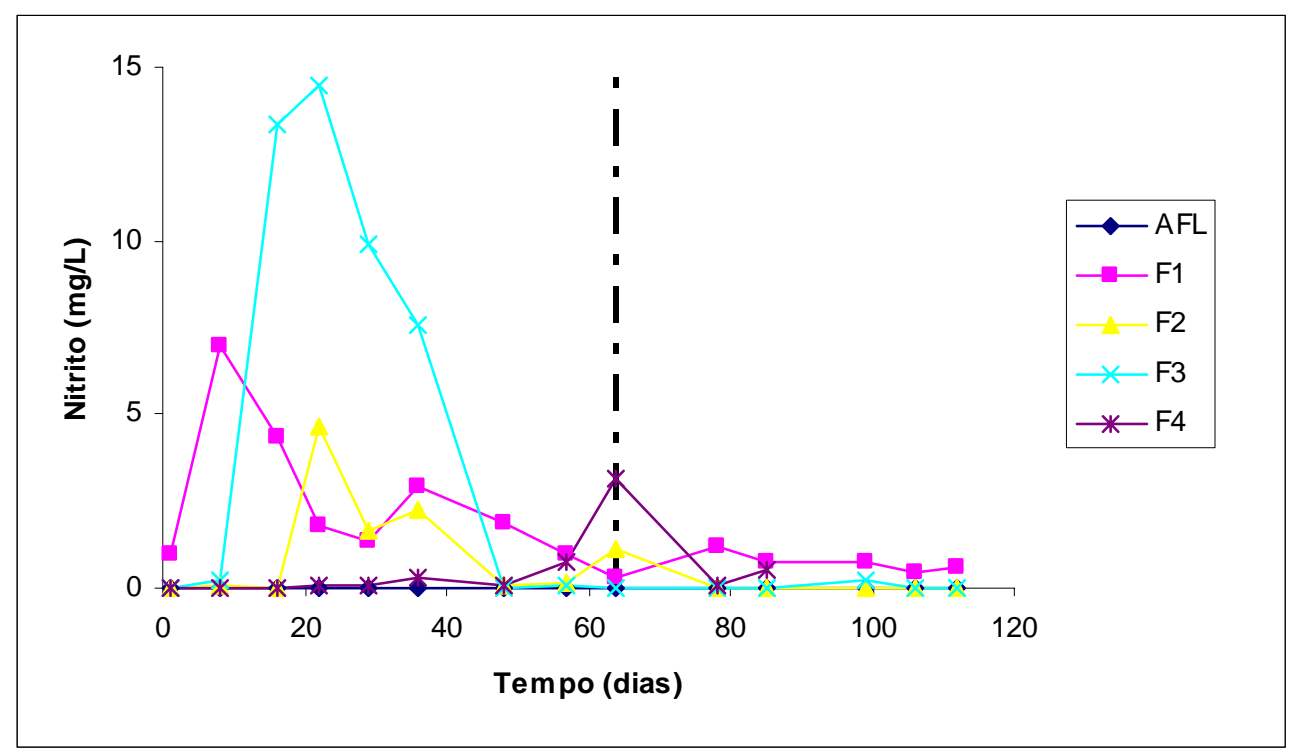

Figura 16 - Variação temporal da concentração de nitrito do esgoto sanitário afluente e efluente dos filtros percoladores

\subsubsection{DQO total}

As Tabelas A 12 e A 13 (Anexo) apresentam as concentrações e eficiências de remoção de DQO total encontradas no esgoto sanitário afluente e nos efluentes dos filtros percoladores. A Figura 17 apresenta a variação temporal da concentração de DQO total.

O filtro F3 apresentou melhores eficiências de remoção que os demais filtros e obteve eficiência média de 71\%. Os filtros F1 e F2 apresentaram eficiências médias de 49\% e 52 \%, respectivamente. O filtro F4 apresentou elevados valores de DQO efluente e apenas $21 \%$ de eficiência de remoção.

O valor médio da DQO afluente no período de operação foi de201 mg/L e para os filtros F1, F2, F3 e F4 os valores da DQO foram, respectivamente, 100mg/L, 92mg/L, 60mg/L e $150 \mathrm{mg} / \mathrm{L}$. 


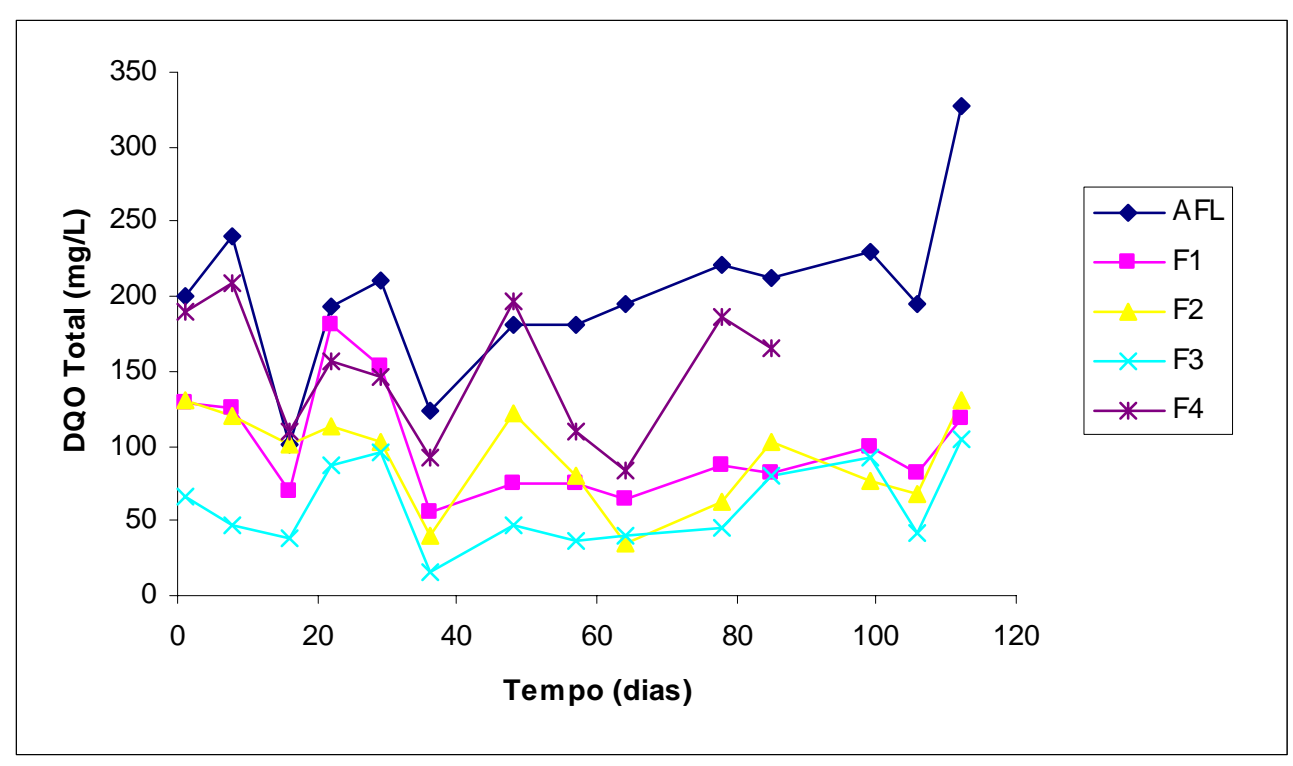

Figura 17 - Variação temporal da concentração de DQO total do esgoto sanitário afluente e efluente dos filtros percoladores

\subsubsection{DQO filtrada}

Nas Tabelas A 14 e A 15 (Anexo) estão expressas as concentrações e eficiências de remoção de DQO filtrada do esgoto afluente e efluente dos filtros percoladores. A Figura 18 apresenta a variação temporal da concentração de DQO filtrada.

Os valores das concentrações de DQO filtrada apresentaram comportamento semelhante à DQO total, porém com valores menores devido à eliminação de pequenas partículas sólidas que ficaram retidas na filtração (membrana de 1,2 $\mu \mathrm{m}$ ). Novamente o filtro F3 apresentou melhores resultados e atingiu eficiência média de 68\%. Os filtros F1, F2 e F4, apresentaram eficiências de 48\%, 57\% e 31\% respectivamente.

A concentração média do esgoto afluente foi de 139mg/L e para o esgoto efluente dos quatro filtros foram, respectivamente, 70mg/L, 58mg/L, 42mg/L e 92mg/L. 




Figura 18 - Variação temporal da concentração de DQO filtrada do esgoto sanitário afluente e efluente dos filtros percoladores

\subsubsection{1 $\mathrm{DBO}_{5}$}

As concentrações de $\mathrm{DBO}_{5}$ estão indicadas na Tabela A 16 (Anexo), as eficiências de remoção na Tabela A 17 (Anexo) e na Figura 19 estes valores estão representados.

De modo geral, em todos os filtros percoladores houve redução nas concentrações de $\mathrm{DBO}_{5}$, sendo que o filtro F3 apresentou melhores resultados e apresentou eficiência média de 67\%. Os demais, F1, F2 e F4, apresentaram eficiências médias de remoção de 50\%, 54\% e $50 \%$, respectivamente. 


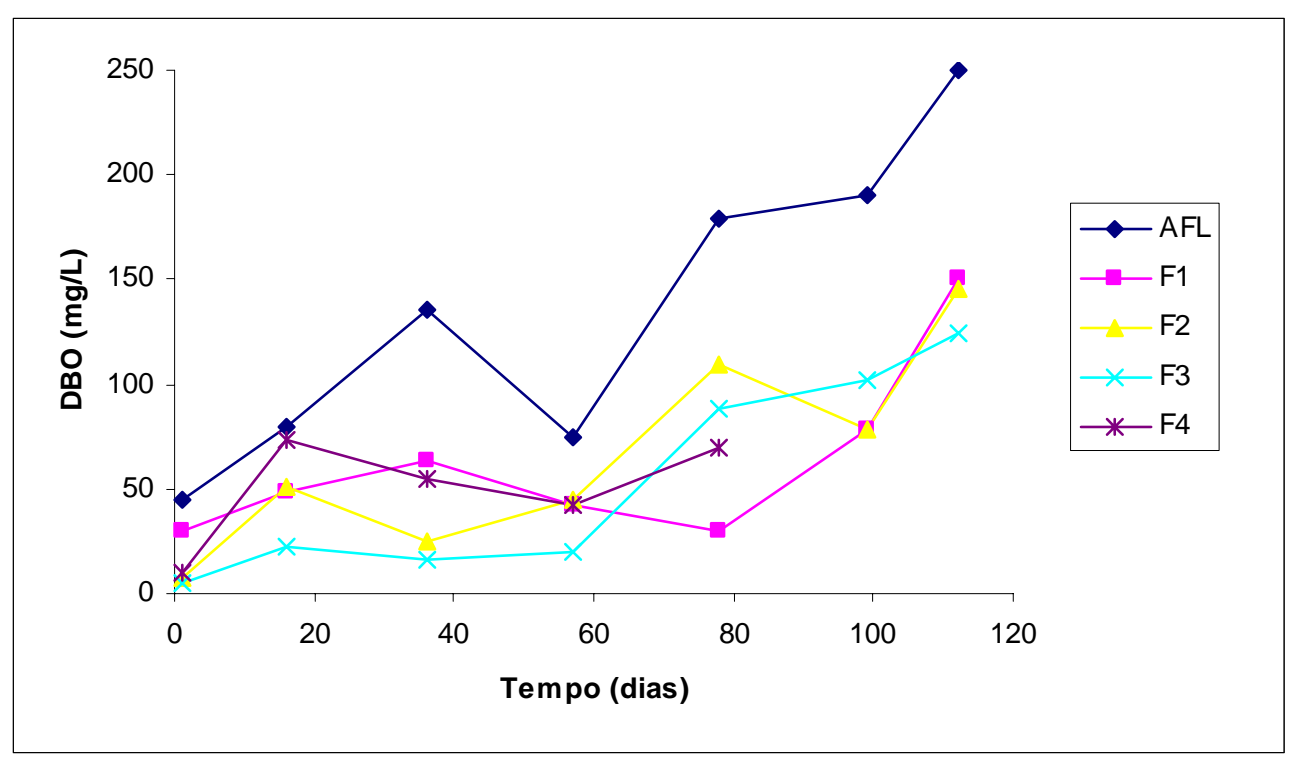

Figura 19 - Variação temporal da concentração de $\mathrm{DBO}_{5}$ do esgoto sanitário afluente e efluente dos filtros percoladores

\subsubsection{Coliformes Totais}

Nas Tabelas A 18 e A 19 (Anexo) encontram-se, respectivamente, os números mais prováveis (NMP) de coliformes totais e as eficiências de remoção nos filtros percoladores. Na Figura 20 estão representados esses números. Em todos os filtros observou-se remoção de coliformes totais e elevadas eficiências de remoção. Essas eficiências foram maiores no início de operação, provavelmente devido a maior concentração de cromo presente em seus efluentes e que deve ter causado toxicidade a esses microrganismos. À medida que o cromo foi sendo lixiviado, a remoção de coliformes totais diminuiu.

As eficiências médias de remoção dos filtros F1, F2, F3 e F4 foram respectivamente 97\%, 95\%, $97 \%$ e $87 \%$.

O filtro F1, mesmo não tendo serragem de couro como meio suporte, apresentou comportamento semelhante aos demais filtros. 


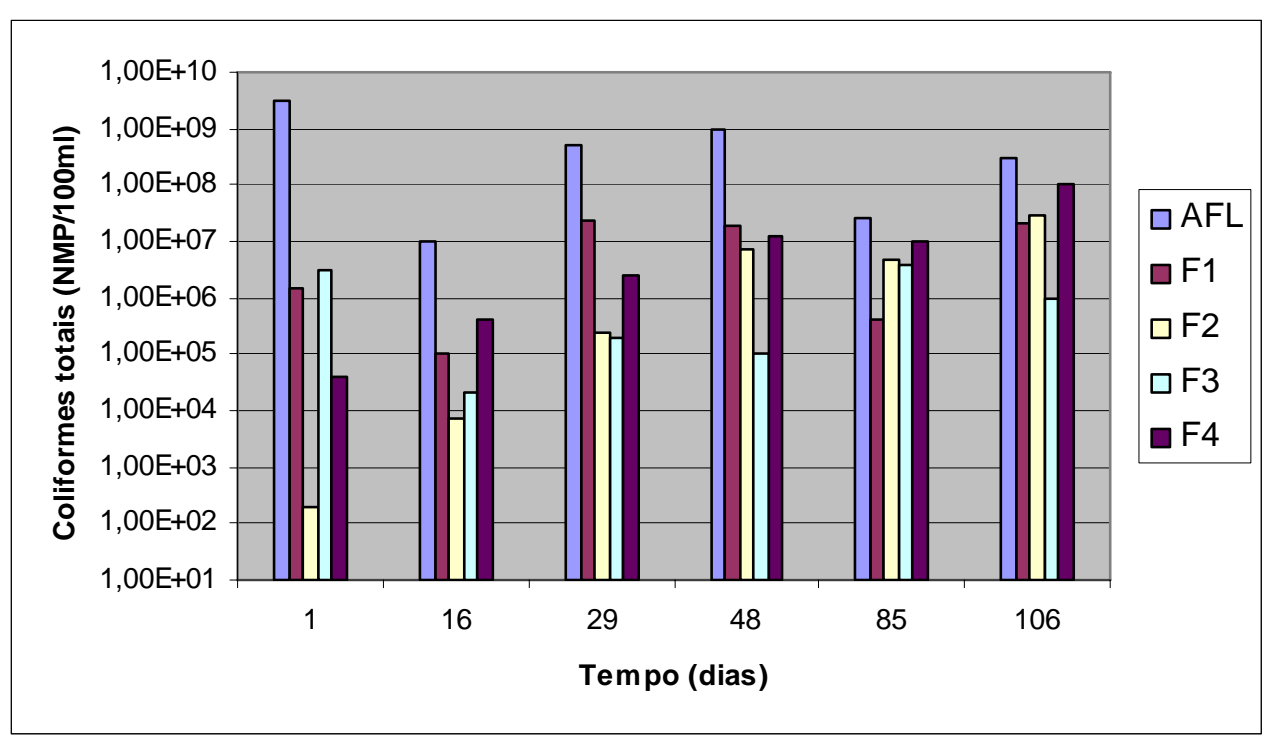

Figura 20 - Número mais provável de coliformes totais do esgoto sanitário afluente e efluente dos filtros percoladores

\subsubsection{Coliformes fecais}

Comportamento semelhante ao ocorrido com os coliformes totais foi observado no número de coliformes fecais e podem ser observados nas Tabelas A 20, A 21 (Anexo) e na Figura 21.

As eficiências médias de remoção para os filtros F1, F2, F3 e F4 foram respectivamente $87 \%$, 91\%, 94\% e $76 \%$. 


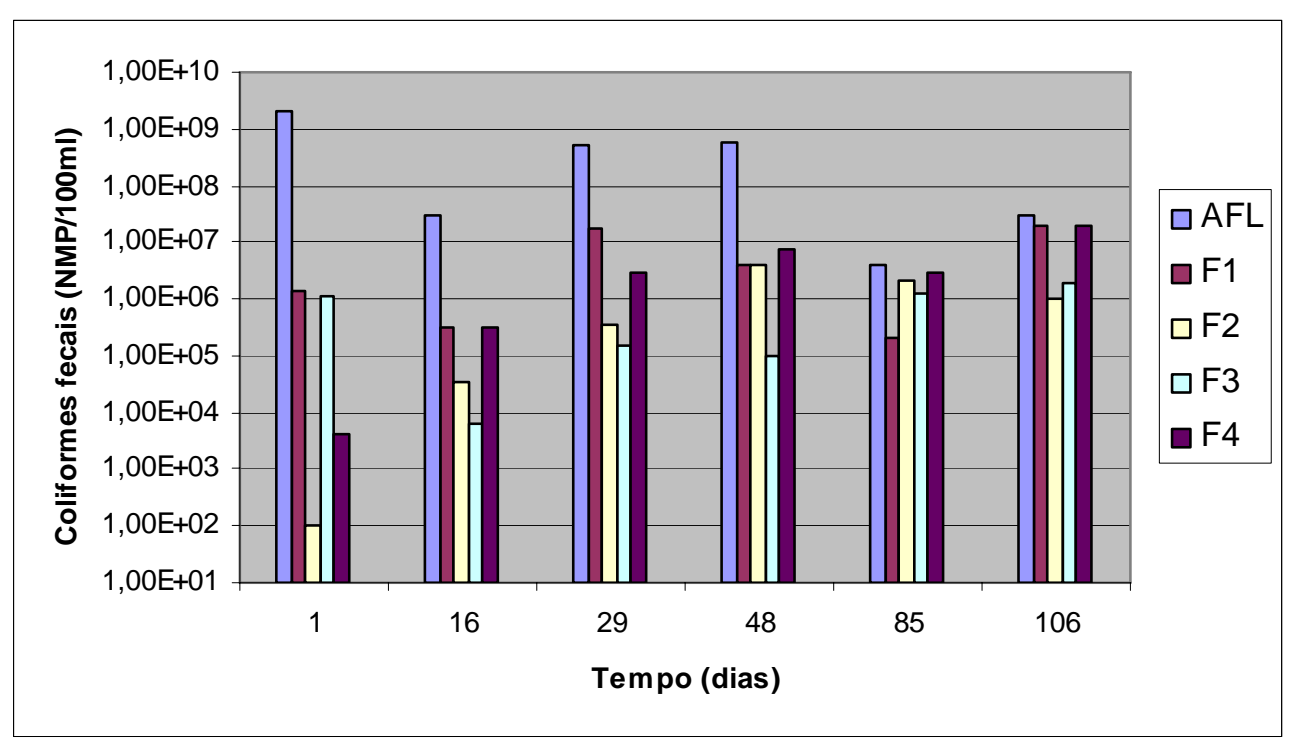

Figura 21 - Número mais provável de coliformes fecais do esgoto sanitário afluente e efluente dos filtros percoladores

\subsubsection{Sólidos}

Nas Tabelas A 22, A 23 e A 24 (Anexo) encontram-se as concentrações de sólidos totais, fixos totais e voláteis totais do esgoto afluente e dos efluentes dos filtros percoladores. A remoção de sólidos não foi muito significativa e algumas vezes foram verificados pequenos acréscimos dessas concentrações, em virtude do carreamento de sólidos finos da serragem e da brita.

Nas Tabelas A 25, A 26 e A 27 (Anexo) encontram-se as concentrações de sólidos suspensos, fixos suspensos e voláteis suspensos.

\subsubsection{Cromo}

As concentrações de cromo nos efluentes dos filtros percoladores foram elevadas apenas no primeiro dia de operação. Após uma semana, as concentrações de cromo nos efluentes de todos os filtros percoladores mantiveram-se abaixo dos valores citados pelo CONAMA 357/05, que é de 0,5mg/L. Esses dados podem ser visualizados na Tabela A 28 (Anexo) e na 
Figura 22.

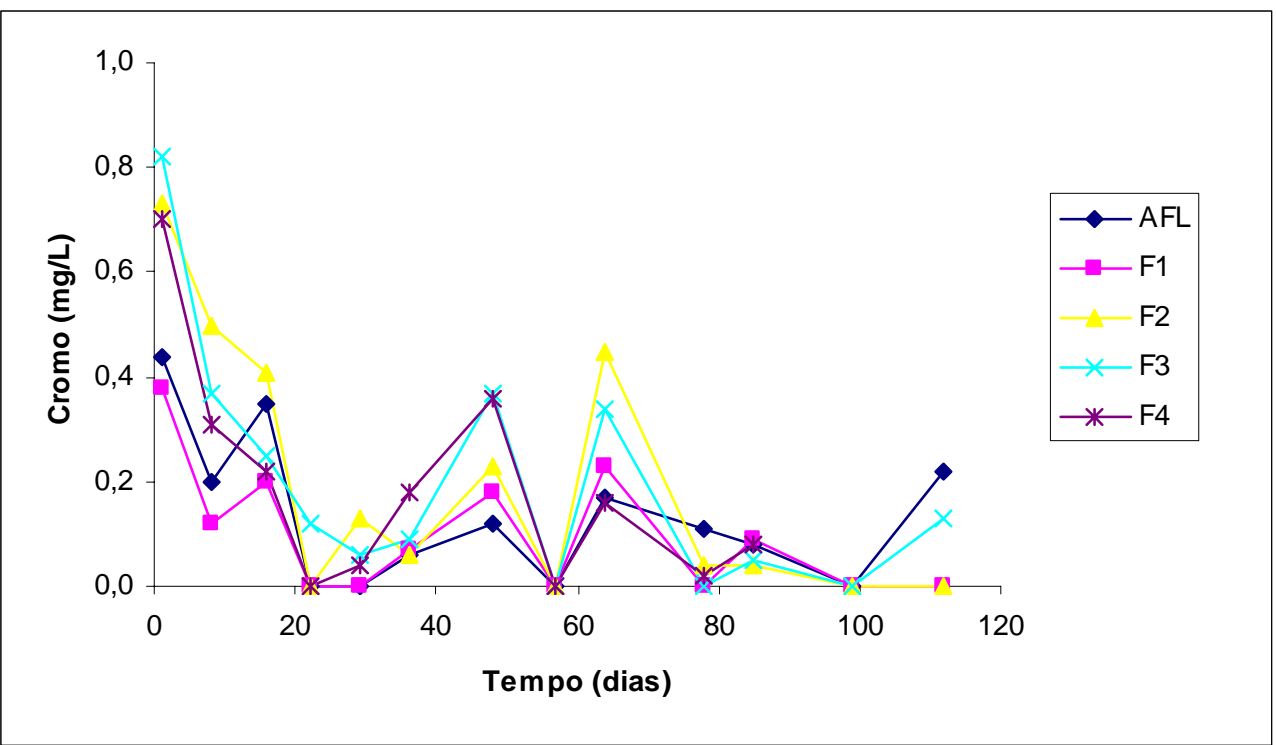

Figura 22 - Variação temporal da concentração de cromo total do esgoto sanitário afluente e efluente dos filtros percoladores

\subsubsection{Outros metais}

Os valores referentes às concentrações de zinco, ferro, manganês e cobre são apresentados nas Tabelas A 29 a A 32 (Anexo).

Chumbo, Cádmio e Níquel não foram detectados nem no esgoto afluente nem nos efluentes dos filtros percoladores.

Manganês e cobre foram encontrados em pequenas quantidades, com concentrações máximas nos efluentes de 0,06mg/L e 0,09mg/L respectivamente. No afluente, a concentração máxima de manganês foi de $0,04 \mathrm{mg} / \mathrm{L}$ e a de cobre foi de $0,13 \mathrm{mg} / \mathrm{L}$.

O zinco também esteve presente em concentrações pequenas nos efluentes, mas superiores às do manganês e do cobre, com valores entre $0,03 \mathrm{mg} / \mathrm{L}$ e $0,56 \mathrm{mg} / \mathrm{L}$. Para o afluente as concentrações variaram de $0,08 \mathrm{mg} / \mathrm{L}$ a $1,23 \mathrm{mg} / \mathrm{L}$

O filtro F1 apresentou concentrações de ferro mais elevadas que os demais, provavelmente provocado pelos sólidos finos arrastados do leito (brita) e que ficavam acumulados na 
mangueira da coleta do efluente. A concentração média de ferro para esse filtro foi de 1,06mg/L, enquanto que para os filtros F2, F3 e F4 foram respectivamente 0,48mg/L, $0,59 \mathrm{mg} / \mathrm{L}$ e $0,42 \mathrm{mg} / \mathrm{L}$.

Todos esses valores enquandram-se dentro dos padrões de lançamentos de efluentes, segundo a resolução CONAMA 357/05.

\subsubsection{Microscopia óptica}

Em três ocasiões durante a operação do sistema foi realizada microscopia óptica, no $6^{\circ}$ (sexto), $41^{\circ}$ (quadragésimo primeiro) e $84^{\circ}$ (octogésimo quarto) dia. No $6^{\circ}$ (sexto) dia, observou-se baixa presença de microrganismos, principalmente no leito de serragem de couro, onde foi encontrada apenas a presença de pequenos flocos (Figura 23). No leito de brita foi observada a presença de amebas (Figura 24) e protozoários flagelados (Figura 25), os quais são indicadores de alta relação F/M segundo Jenkins et al.(1993).

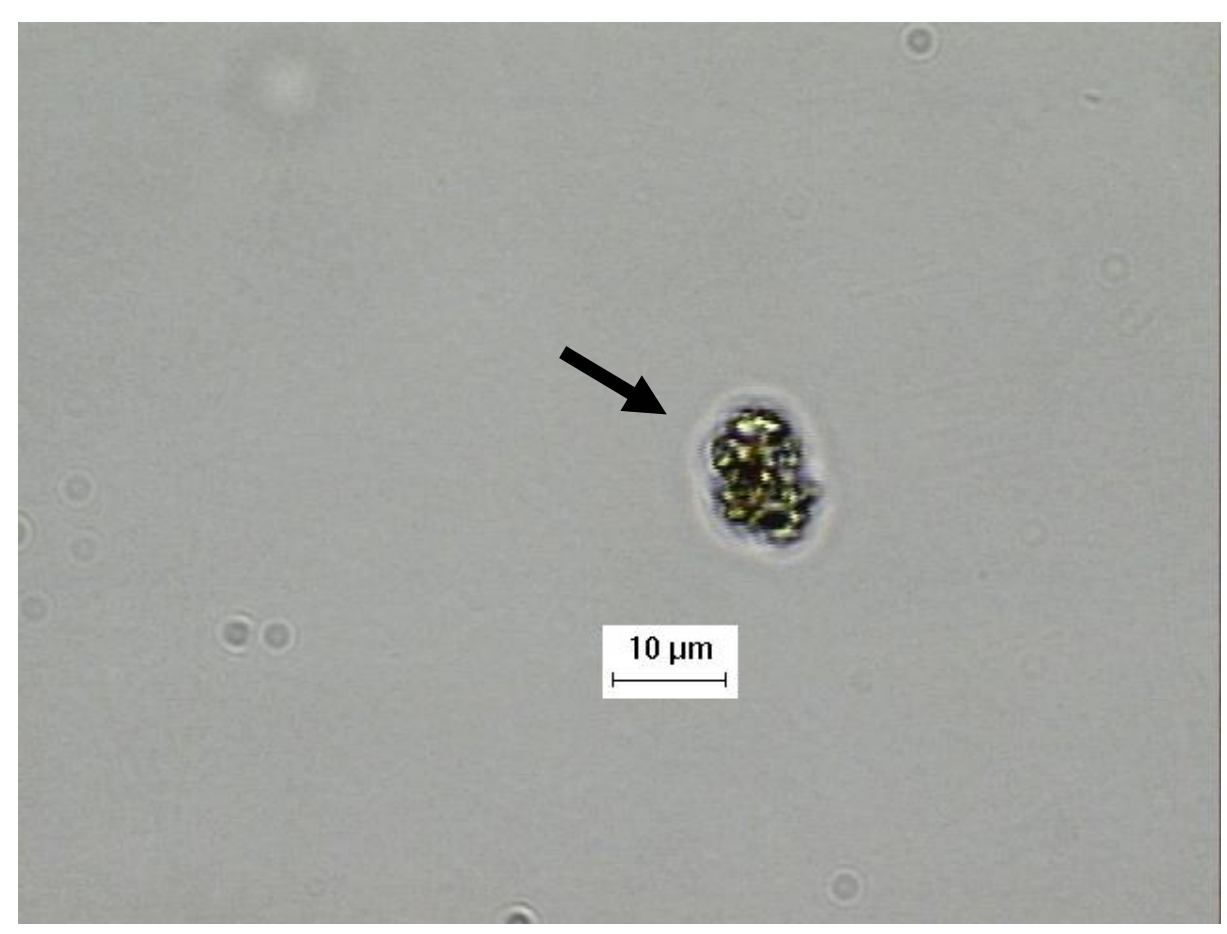

Figura 23 - Floco observado na serragem de couro utilizada no filtro percolador $\left(6^{\circ}\right.$ dia de operação) 


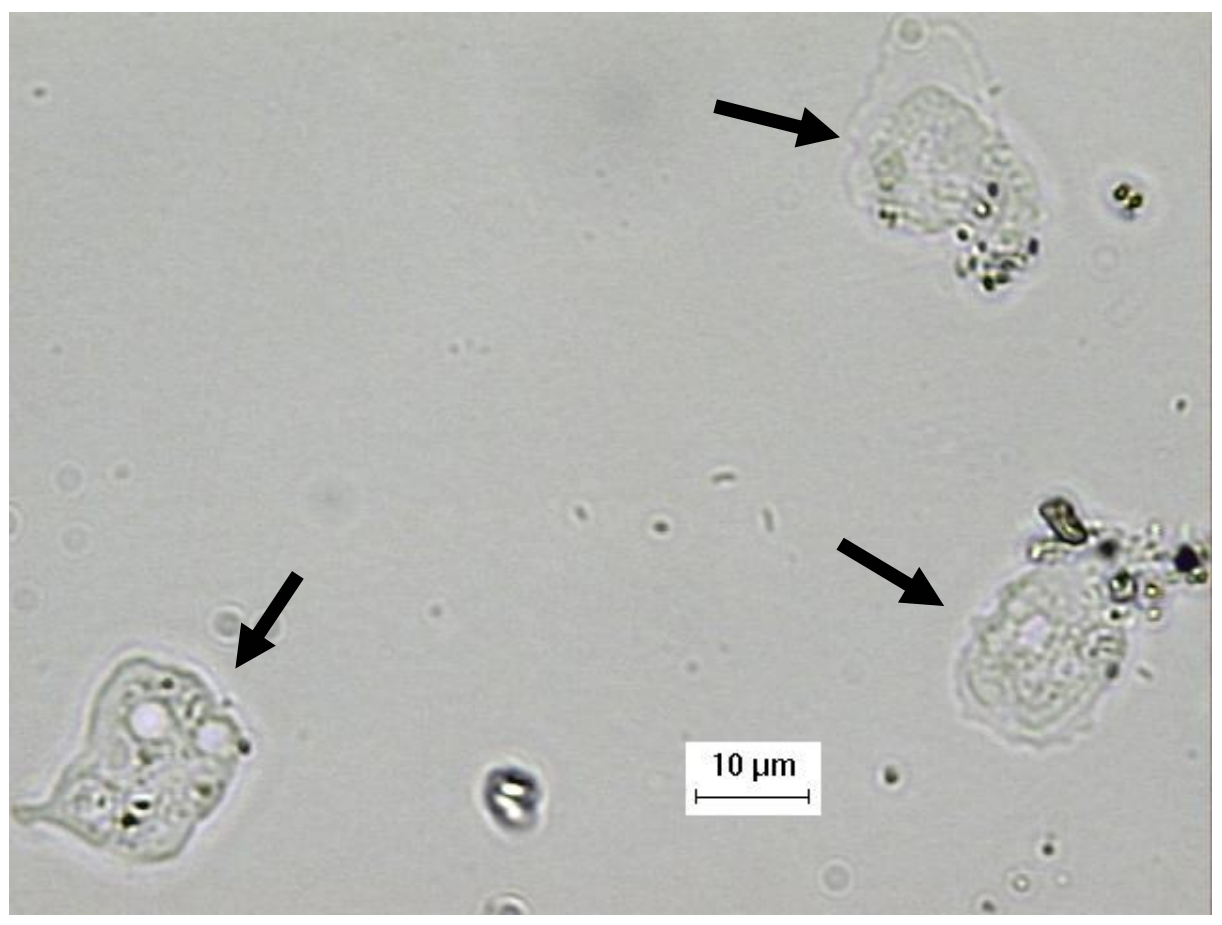

Figura 24 - Amebas observadas na brita utilizada no filtro percolador (6º dia de operação)

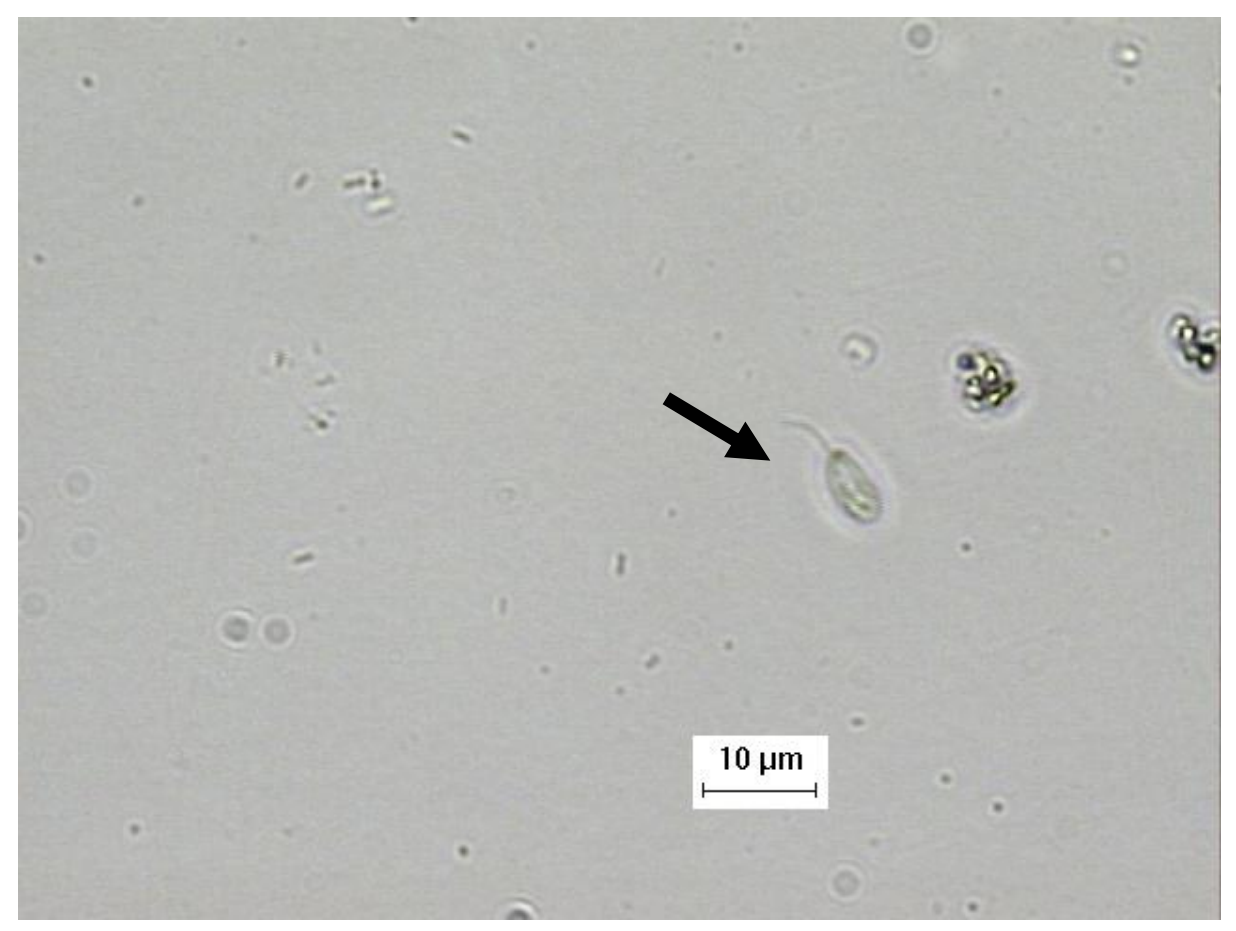

Figura 25 - Protozoário flagelado observado na brita utilizada no filtro percolador ( $6^{\circ}$ dia de operação)

No $41^{\circ}$ (quadragésimo primeiro) dia, foi observada maior colonização por microrganismos. Na serragem de couro verificou-se a presença de bacilos (Figura 26), protozoários flagelados 
(Figura 27) e pedunculados (Figura 28). Na brita foi observada apenas a presença de bacilos (Figura 29).



Figura 26 - Bacilos observados na serragem de couro utilizada no filtro percolador ( $41^{\circ}$ dia)



Figura 27 - Protozoário flagelado observado na serragem de couro utilizada no filtro percolador $\left(41^{\circ}\right.$ dia $)$ 


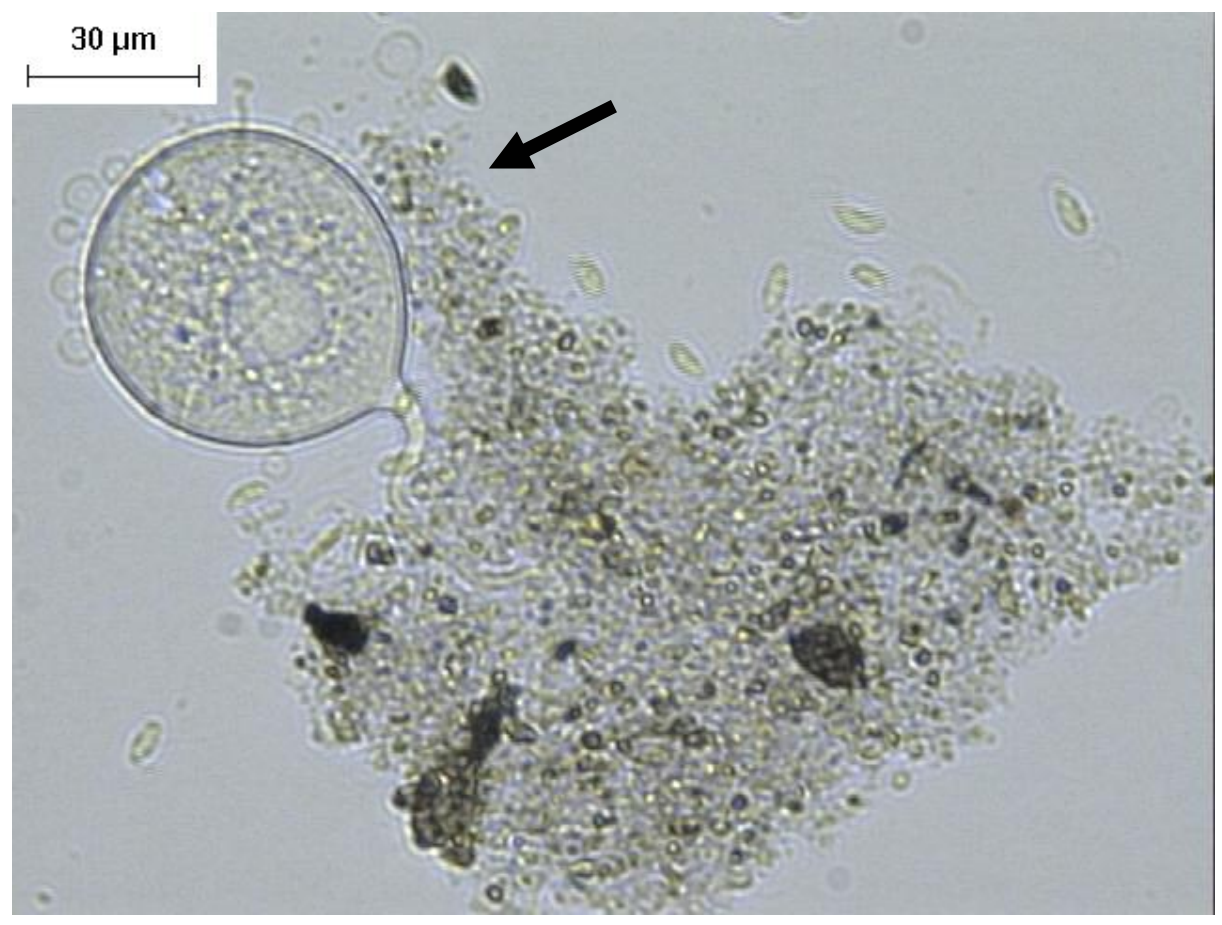

Figura 28 - Protozoário pedunculado observado na serragem de couro utilizada no filtro percolador $\left(41^{\circ}\right.$ dia $)$

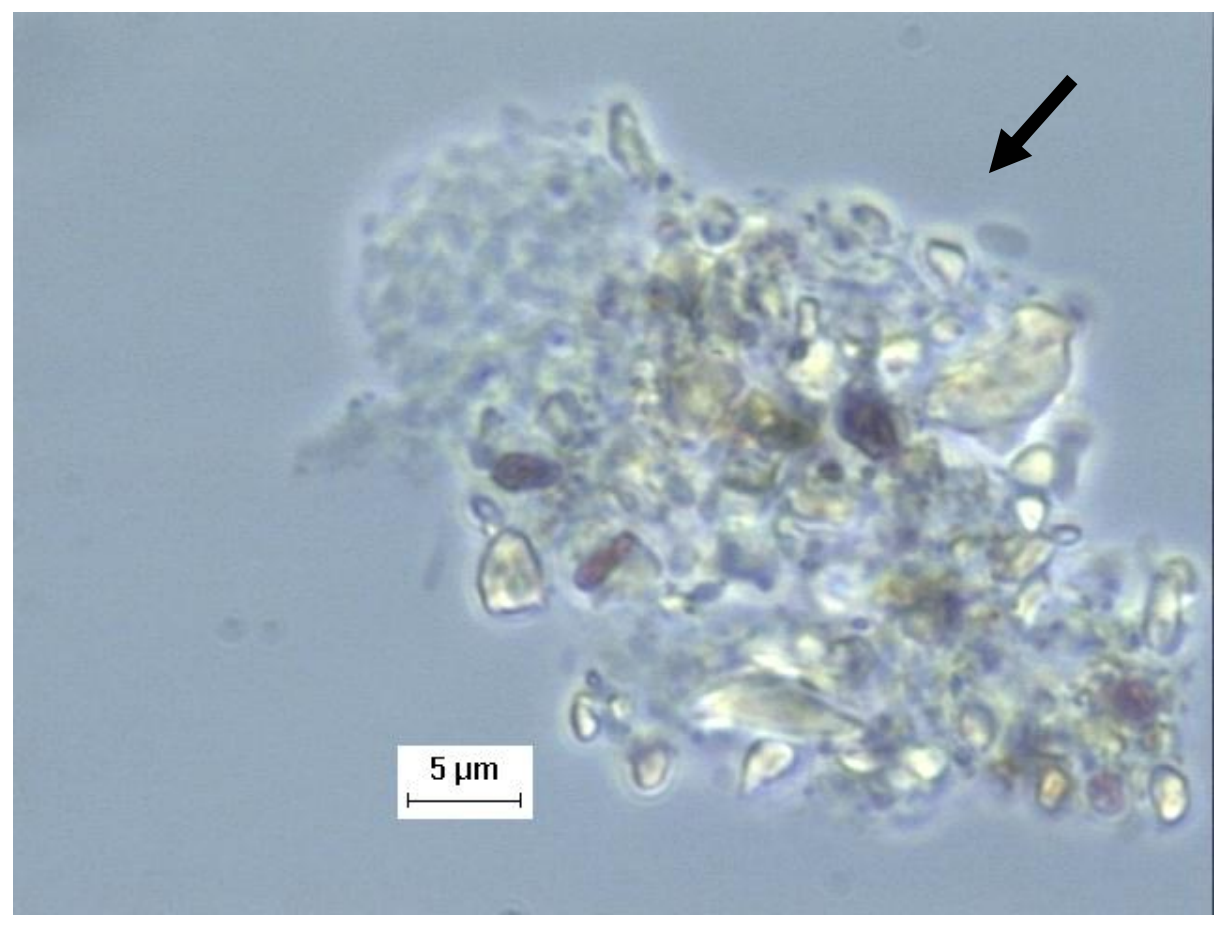

Figura 29 - Bacilos observados na brita utilizada no filtro percolador ( $41^{\circ}$ dia)

No $84^{\circ}$ (octogésimo quarto) dia foi observado maior diversidade de microrganismos nos leitos. Na serragem de couro foi observada a presença de flocos, amebas com carapaças e 
microrganismos semelhantes à Beggiatoa. Na brita foram encontrados amebas com carapaças, rotíferos e flagelados. Segundo Branco (1986), a presença de rotíferos indica alta eficiência no processo de tratamento.

As Figuras 30, 31 e 32 mostram algumas morfologias observadas nesse dia.

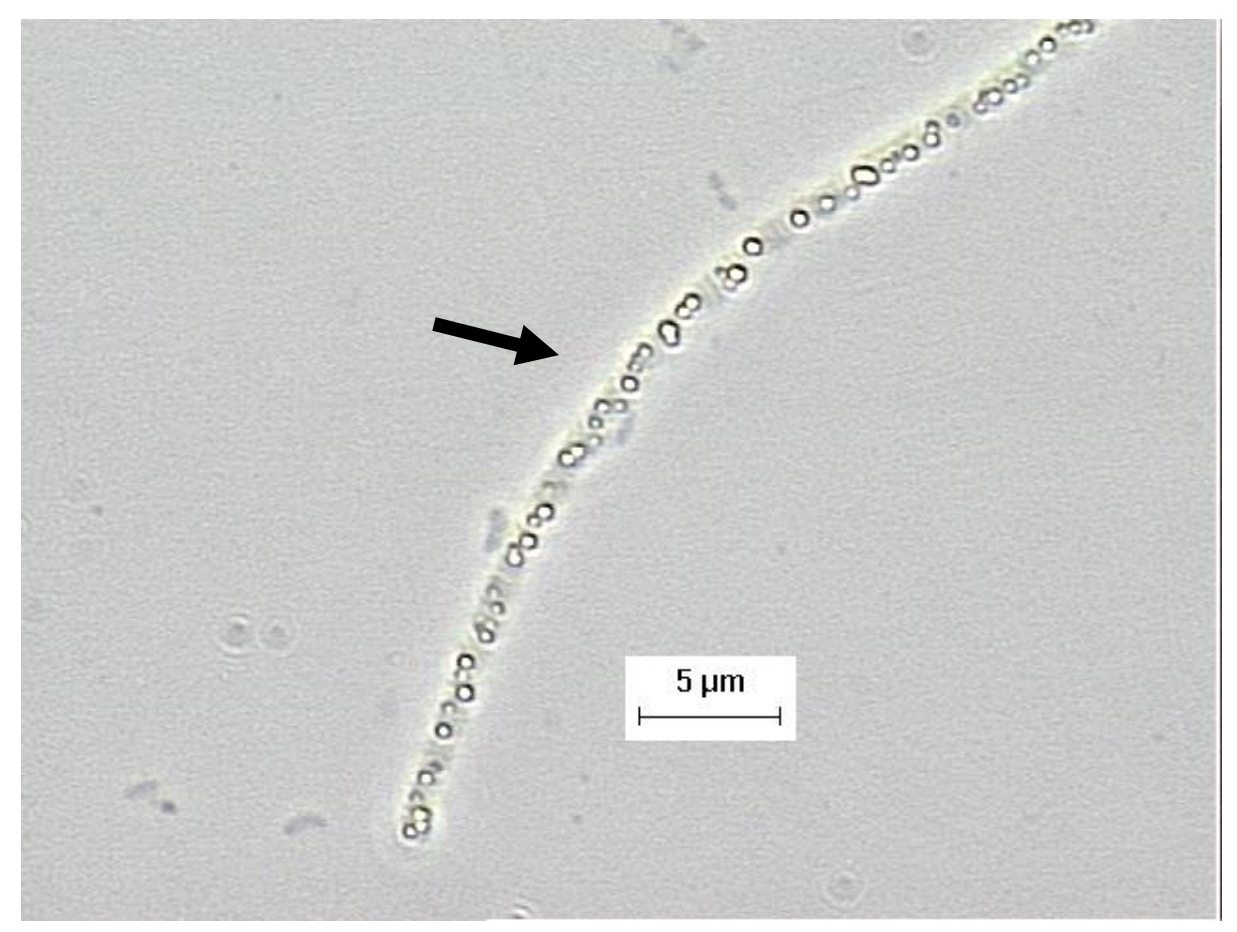

Figura 30 - Microrganismo semelhante à Beggiatoa observada na serragem de couro utilizada no filtro percolador $\left(84^{\circ} \mathrm{dia}\right)$ 


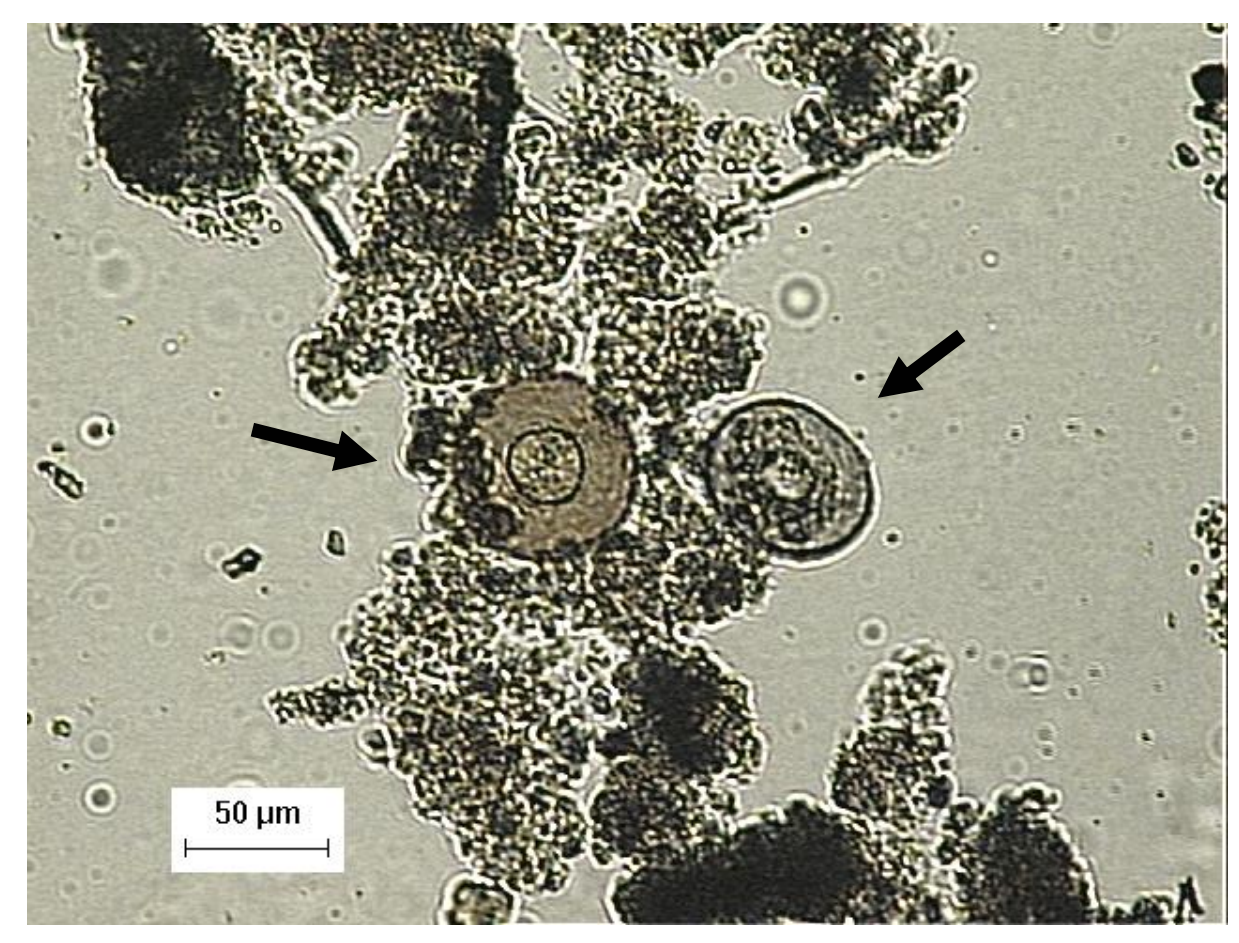

Figura 31 - Amebas com carapaças observadas na brita utilizada no filtro percolador ( $84^{\circ}$ dia)

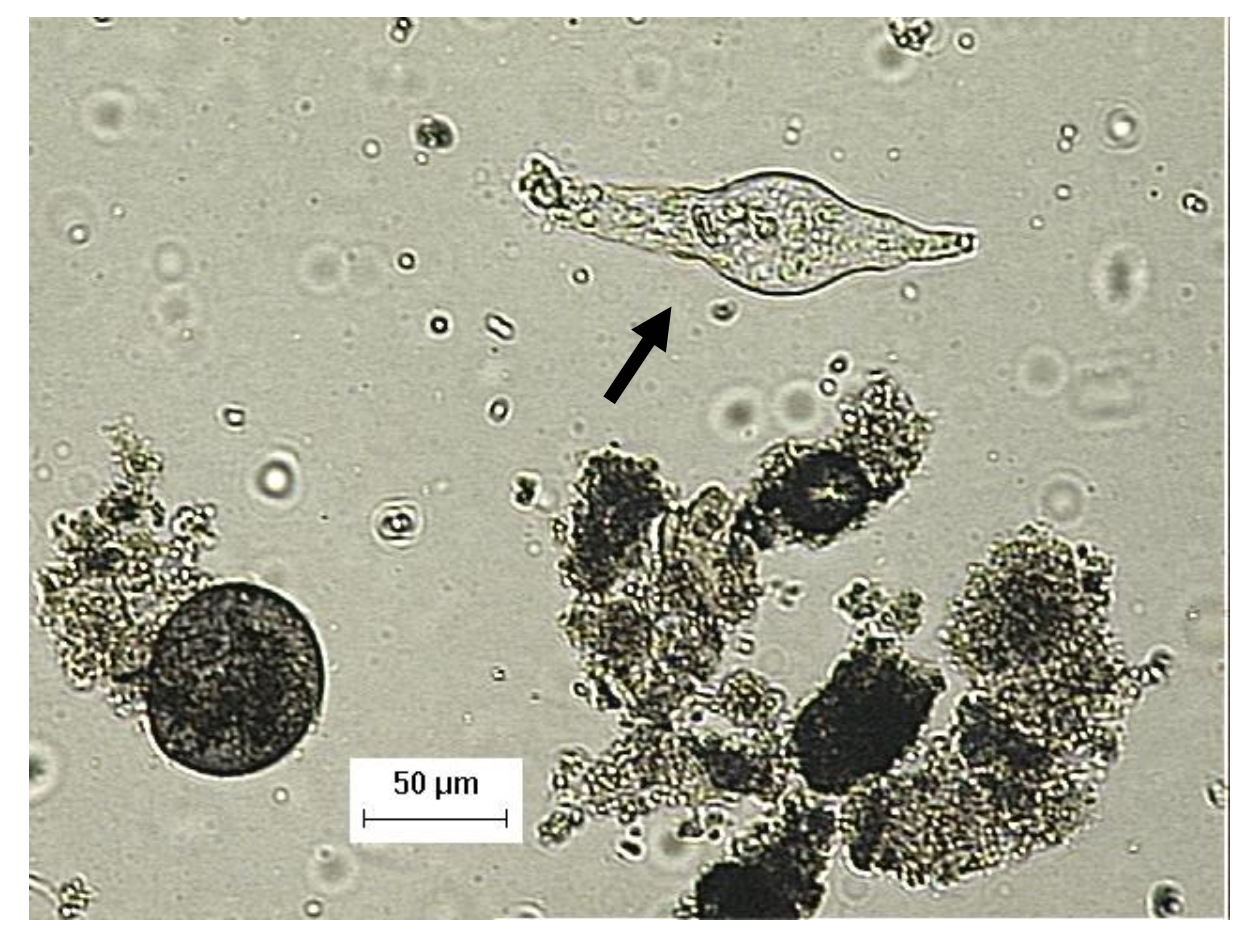

Figura 32 - Rotífero observado na brita utilizada no filtro percolador (84 dia) 


\section{CONCLUSÕES}

O trabalho realizado, utilizando filtros percoladores para pós-tratamento de esgoto sanitário, permitiu concluir que:

$>$ A utilização da serragem de couro em filtros se mostrou uma alternativa viável do ponto de vista ambiental para disposição desse resíduo.

Os filtros percoladores preenchidos com serragem de couro mostraram-se eficientes para o pós-tratamento de esgoto sanitário com reduções significativas nas concentrações de matéria orgânica e nitrogênio.

As lavagens da serragem foram de grande importância para redução das concentrações de cromo no efluente, pois após uma semana de operação, as concentrações de cromo nos efluentes de todos os filtros percoladores mantiveramse abaixo dos valores citados pelo CONAMA 357/05, que é de 0,5mg/L.

O filtro F3 apresentou melhores resultados para todos os parâmetros analisados com eficiências médias de remoção de DQO total, NTK e N-NH 3 de 71\% para os três parâmetros. A partir do $64^{\circ}$ (sexagésimo quarto) dia, esse filtro passou a apresentar 100\%de remoção de $\mathrm{NTK}$ e $\mathrm{N}-\mathrm{NH}_{3}$. Os filtros F1 e F2 podem ter tido problemas com a aeração, já que foram operados com menor taxa de aplicação hidráulica e deveriam apresentar melhores resultados.

$>$ Comparando o filtro F1 (brita) e o filtro F2 (serragem de couro), este último apresentou melhores eficiências de remoção para turbidez, NTK, N-NH 3, DQO total, DQO filtrada e $\mathrm{DBO}_{5}$, porém essas diferenças foram pequenas.

O filtro F4 apresentou os piores resultados provavelmente devido a maior taxa de aplicação hidráulica. O processo de nitrificação ocorreu em pequena proporção nesse filtro. 
$>$ Ocorreu redução de coliformes totais e fecais em todos os filtros, sendo que o filtro F3 apresentou as maiores eficiências: 97\% para coliformes totais e 94\% para fecais. Acredita-se que o processo de nitrificação tenha se estabelecido próximo ao $60^{\circ}$ (sexagésimo) dia de operação, quando as reduções de $\mathrm{NTK}$ e N-NH 3 passaram a ser mais significativas e as concentrações de nitrato aumentaram.

$>$ Foram observados picos nas concentrações de nitrito, que podem ter sidos provocados por deficiência na aeração, já que as bactérias responsáveis pela nitratação são mais sensíveis às baixas concentrações de O.D.

$>$ Com o exame microscópio, verificou-se que as condições de operação dos filtros permitiram a colonização de biomassa diversificada em ambos os leitos, tais como bacilos, amebas, flagelados e rotíferos. 


\section{RECOMENDAÇÕES}

De acordo com os resultados obtidos durante a operação do sistema são feitas as seguintes sugestões para pesquisas futuras:

$>$ Realizar um estudo mais aprofundado sobre a degradabilidade e durabilidade da serragem de couro como meio suporte.

Promover a desnitrificação dos efluentes dos filtros percoladores F1, F2, F3 e F4 através do uso de reatores anaeróbios.

Promover a recirculação do efluente no filtro F4, operado com maior taxa aplicação hidráulica.

> Monitorar a concentração de oxigênio dissolvido e verificar a sua interferência na nitrificação para diferentes concentrações.

Realizar testes de toxicidade crônica, a fim de avaliar com minuciosidade os efeitos provocados pelo cromo presente na serragem aos microrganismos responsáveis pela degradação da matéria orgânica.

$>$ Prolongar o período de funcionamento do sistema, tendo em vista verificar se os resultados de remoção de matéria orgânica e nitrogênio persistem.

Aplicar o processo utilizado para lixiviado de aterro sanitário. 


\section{REFERÊNCIAS BIBLIOGRÁFICAS}

APHA, AWWA, WPFC (1998). Standard Methods for the Examination of Water and Wastewater - 20a Edition, Washington, D. C. 1268 p.

BABU, N. K. C.; ASMA, K.; RAGHUPATHI, A.; VENBA, R.; RAMESH, R.; SADULLA, S. (2004) - Screening of leather auxiliaries for their role in toxic hexavalent chromium formation in leather - posing potential health hazards to the users - Journal of Cleaner Production.

BARNES D.; BLISS, P. J. (1983) - Biological control nitrogen in wastewater treatment - E. \& F. N. Spon, Cambridge, Great Britain. 146 p.

BELÉM, B. D. (1996) - Pós tratamento de efluentes de esgoto sanitário através de filtro biológico com taxas variáveis. Dissertação (Mestrado) - Universidade de São Paulo Escola de Engenharia de São Carlos - São Carlos - SP.101p.

BIDONE, F. R. A. (1995) - A vermicompostagem dos resíduos sólidos de curtume, brutos e previamente lixiviados, utilizando compostos de lixo orgânico como substrato. Tese (Doutorado) - Universidade de São Paulo - Escola de Engenharia de São Carlos - São Carlos - SP. 184 p.

BRAILE, P. M. Manual de tratamento de águas residuárias industriais. São Paulo: CETESB, 1993. 764p.

BRANCO, S.M. (1986) - Hidrobiologia aplicada à engenharia sanitária - $3^{\circ}$ ed. São Paulo: CETESB/ASCETESB. 640p.

BRITO, A.L. F.; MUNIZ, A.C.S.; LOPES, W.S.; LEITE, V.D.; PRASAD. S. (2002) Processo de codisposição de resíduos sólidos industriais de curtume - Revista Engenharia Sanitária e Ambiental vol.7, no 3. 
CALLADO, N.H. \& FORESTI, E. (2001). Removal of organic carbon, nitrogen and phosphorus in sequential batch reactorsintegrating the aerobic/anaerobic process. Water Science ans Technology, V.44, N.04, p.263-270.

CAMPOS, J. R. (1994) - Alternativas para tratamento de esgostos - Pré-tratamento de águas para abastecimento - Consórcio Intermunicipal das bacias do Rio Piracicaba e Capivari.Americana-SP.

CETESB - Companhia de Tecnologia de Saneamento Ambiental (1980). Resíduos de curtumes - São Paulo: CETESB, 86 p.

ECKENFELDER Jr, W. W. (1989) - Industrial water pollution control - Singapore McGraw-Hill International Editions - 2a edição.

FORD, D. L.; CHURCHWELL, R. L.; KACHTICK, J. W. (1980). Comprehensive analysis of nitrification of chemical processing wastewaters. Journal Water Pollution Control Federation, v.52, n.11, p.2726-46.

GRADY, C.P.L. \& LIM, H.C. (1981). Biological wastewater treatment: theory and applications. M. Dekker, New York, 963p.

GUNSÉ, B.; POSCHENRIEDER, C. H.; BARCELÓ, J. (1992). O cromo e o uso de lodo de curtume na agricultura. Revista do Couro, p. 100-104, jun.

HENZE, M.; HARREMOËS, P.; JANSEN, J.L.C.; ARVIN, E. (1997). Wastewater treatment, 2nd ed. Germany. Springer.

HOINACKI, E.; MOREIRA. M. V. (1994) - Fluxograma da transformação da pele em couro acabado. In: HOINACKI, Eugênio et al. Manual básico de processamento de couro. Porto Alegre - SENAI - Cap.5. 
HORAN, N.J. (1990). Biological wastewater treatment systems: theory and operation.John Wiley \& Sons, Chichester - England, 310 p.

JENKINS, D.; RICHARD, M.G. \& DAIGGER, G.T. (1993). Manual on the causes and control of activated sludge bulking and foaming. $2^{\circ}$ ed., Lewis Publishers, Michigan, 193p.

JIANLONG, W.; ZEYU, M.; XUAN, Z. - Response os Saccharomyces to chromium stress Process Biochemistry, V.39, p. 1231-1235.

JOST, P.T. (1990). Tratamento de Efluentes de Curtume. Rio de Janeiro, CNI, 1990. p.185.

METCALF \& EDDY (2003). Wastewater Engineering: Treatment, Disposal and Reuse - 3a ed. Mc Graw - Hill. New York. 1819p.

MOREIRA, S. L. S. (2003) - Pós-tratamento de esgoto sanitário tratado em reator anaeróbio com o uso de serragem de couro curtido tipo wet blue como meio suporte de filtros percoladores - Dissertação (Mestrado) - Universidade de São Paulo - Escola de Engenharia de São Carlos - São Carlos - SP - 123p.

NUSSBAUM, D. F. (2001)- O efeito dos sais de cromo de basicidade diferente - Revista do couro - Ed. 154 - Março-Abril 2002 - p. 62 - 71

PESSÔA, C.A., JORDÃO, E.P. (2005) - Tratamento de esgotos domésticos - $4^{\mathrm{a}}$ edição Associação brasileira de Engenharia Sanitária - ABES - Rio de Janeiro - RJ.

POVINELLI, J. (1987). Ação dos metais pesados nos processos biológicos de tratamento de águas residuárias. Tese Livre Docência em Hidráulica e Saneamento - Universidade de São Paulo - Escola de Engenharia de São Carlos -São Carlos - SP. 348p.

POVINELLI, S. C. S. (1999). Cinética, hidrodinâmica e biomassa em reator anaeróbio compartimentado alimentado com esgoto sanitário. Tese (Doutorado) - Universidade de São Paulo - Escola de Engenharia de São Carlos - São Carlos - SP. 137 p. 
RÊGO V. M. S. (2002). Estudo da atividade biológica das células imobilizadas em um reator anaeróbio tratando esgoto sanitário. Dissertação (Mestrado) - Universidade de São Paulo - Escola de Engenharia de São Carlos São Carlos -SP. 113 p.

REVISTA COURO BUSINESS (2004a) - Revista Courobusiness - Edição No 34 - Ano IV Mai/Jun 2004. Disponível em: http://www.courobusiness.com.br/Couro\%20Mundial.htm. Acesso em: 10 Jan. 2005.

REVISTA COURO BUSINESS (2004b)- Revista Courobusiness - Edição No 32 - Jan/Fev 2004. Disponível em: http://www.courobusiness.com.br/Balan\%C3\%A7o2003.htm. Acesso em: 10 Jan. 2005.

ROJAS, J.A.R (1999) Tratamiento de águas residuales: teoria y principios de diseño. $1^{\circ}$ ed, Editorial Escuela Colombiana de Ingenieria, Santafé de Bogotá, 1232p.

RUSSELL, J. B. (1994) - Química geral - Pearson Education do Brasil - 2ª edição - volume $2-1268 p$.

SONGMING, Z. \& SHULIN, C (2002). - The impact of temperature on nitrification rate in fixed film biofilters. Aquacultural Engineering, v.26, p. 221-237.

SOUZA, L. F. (1999). Serragens de couro curtido tipo wet blue, utilizadas como meio suporte de filtros percoladores, destinados ao tratamento de esgoto sanitário. Dissertação (Mestrado) - Universidade Federal do Rio Grande do Sul - Instituto de Pesquisas Hidráulicas - IPH - Porto Alegre - RS. 246 p.

SPERLING, M. V. (1997) - Princípios do tratamento biológico de águas residuárias. Belo Horizonte: Departamento de Engenharia Sanitária e Ambiental - Universidade Federal de Minas Gerais.

SUASSUNA, R. C. A. (2004). Utilização de serragem de couro do tipo wet blue como meio suporte de filtros percoladores para pós-tratamento de esgoto sanitário tratado em reator 
anaeróbio compartimentado. Tese (Doutorado) - Universidade de São Paulo - Escola de Engenharia de São Carlos - São Carlos - SP - 175p.

SURAMPALLI, R.; TYAGI, R.D.; SCHEIBLE, O.K.; HEIDMAN, J.A (1997). Nitrification, denitrification and phosphorus removal in sequential batch reactors. Bioresource Technology, v.61, p. 151-157.

WIJFFELS, R .H.; TRAMPER, J. (1995). Review: nitrification by immobilized cells. Enzyme and Microbial Thecnology, v. 17, p. 482-492. 
ANEXO

RESULTADOS DAS ANÁLISES OBTIDOS DURANTE OPERAÇÃO DO SISTEMA 
Tabela A 1 - pH do esgoto sanitário afluente e efluente dos filtros percoladores

\begin{tabular}{|c|c|c|c|c|c|c|}
\hline Data & Tempo (dias) & AFL & F1 & F2 & F3 & F4 \\
\hline $24 / 8 / 2005$ & 1 & 6,8 & 7,5 & 5,7 & 6,6 & 6,2 \\
\hline $27 / 8 / 2005$ & 4 & 6,8 & 7,3 & 6,0 & 6,8 & 6,4 \\
\hline $31 / 8 / 2005$ & 8 & 6,9 & 7,2 & 7,6 & 8,2 & 7,2 \\
\hline $6 / 9 / 2005$ & 14 & 6,8 & 7,1 & 7,5 & 7,4 & 7,2 \\
\hline $8 / 9 / 2005$ & 16 & 6,8 & 7,3 & 7,5 & 6,7 & 7,3 \\
\hline $14 / 9 / 2005$ & 22 & 6,9 & 7,4 & 7,8 & 6,1 & 7,5 \\
\hline $21 / 9 / 2005$ & 29 & 7,0 & 7,5 & 7,9 & 7,0 & 7,5 \\
\hline $28 / 9 / 2005$ & 36 & 7,0 & 7,2 & 7,7 & 6,4 & 7,6 \\
\hline $10 / 10 / 2005$ & 48 & 6,9 & 7,0 & 7,2 & 5,7 & 7,1 \\
\hline $19 / 10 / 2005$ & 57 & 6,8 & 6,9 & 7,5 & 5,1 & 7,2 \\
\hline $26 / 10 / 2005$ & 64 & 6,7 & 6,7 & 7,1 & 5,4 & 7,3 \\
\hline $9 / 11 / 2005$ & 78 & 7,0 & 6,2 & 7,2 & 5,5 & 7,1 \\
\hline $16 / 11 / 2005$ & 85 & 6,6 & 7,0 & 6,9 & 5,3 & 6,4 \\
\hline $30 / 11 / 2005$ & 99 & 6,7 & 6,8 & 6,5 & 5,2 & - \\
\hline $7 / 12 / 2005$ & 106 & 6,7 & 6,6 & 6,7 & 5,4 & - \\
\hline $13 / 12 / 2005$ & 112 & 6,6 & 6,7 & 6,8 & 5,2 & - \\
\hline \multicolumn{2}{|c|}{ Média } & 6,8 & 7,0 & 7,1 & 6,1 & 7,1 \\
\hline
\end{tabular}

Tabela A 2 - Condutividade do esgoto sanitário afluente e efluente dos filtros percoladores $(\mathrm{mS} / \mathrm{cm})$

\begin{tabular}{|c|c|c|c|c|c|c|}
\hline Data & Tempo (dias) & AFL & F1 & F2 & F3 & F4 \\
\hline $24 / 8 / 2005$ & 1 & 0,370 & 0,431 & 0,495 & 0,515 & 0,755 \\
\hline $31 / 8 / 2005$ & 8 & 0,590 & 0,400 & 0,620 & 0,530 & 0,580 \\
\hline $8 / 9 / 2005$ & 16 & 0,384 & 0,380 & 0,435 & 0,400 & 0,425 \\
\hline $14 / 9 / 2005$ & 22 & 0,335 & 0,326 & 0,301 & 0,276 & 0,353 \\
\hline $21 / 9 / 2005$ & 29 & 0,420 & 0,370 & 0,330 & 0,372 & 0,415 \\
\hline $28 / 9 / 2005$ & 36 & 0,460 & 0,405 & 0,420 & 0,320 & 0,410 \\
\hline $10 / 10 / 2005$ & 48 & 0,378 & 0,305 & 0,360 & 0,305 & 0,370 \\
\hline $19 / 10 / 2005$ & 57 & 0,410 & 0,335 & 0,350 & 0,330 & 0,395 \\
\hline $26 / 10 / 2005$ & 64 & 0,320 & 0,452 & 0,317 & 0,268 & 0,334 \\
\hline $9 / 11 / 2005$ & 78 & 0,420 & 0,350 & 0,410 & 0,315 & 0,370 \\
\hline $16 / 11 / 2005$ & 85 & 0,395 & 0,420 & 0,350 & 0,287 & 0,390 \\
\hline $30 / 11 / 2005$ & 99 & 0,440 & 0,385 & 0,400 & 0,320 & - \\
\hline $7 / 12 / 2005$ & 106 & 0,350 & 0,320 & 0,445 & 0,340 & - \\
\hline $13 / 12 / 2005$ & 112 & 0,420 & 0,355 & 0,387 & 0,375 & - \\
\hline \multicolumn{2}{|c|}{ Média } & 0,407 & 0,374 & 0,401 & 0,354 & 0,436 \\
\hline
\end{tabular}


Tabela A 3 - Turbidez do esgoto sanitário afluente e efluente dos filtros percoladores (UNT)

\begin{tabular}{|c|c|c|c|c|c|c|}
\hline Data & Tempo (dias) & AFL & F1 & F2 & F3 & F4 \\
\hline $24 / 8 / 2005$ & 1 & 39 & 19 & 10 & 7 & 22 \\
\hline $31 / 8 / 2005$ & 8 & 111 & 11 & 13 & 4 & 34 \\
\hline $8 / 9 / 2005$ & 16 & 33 & 9 & 18 & 3 & 41 \\
\hline $14 / 9 / 2005$ & 22 & 89 & 26 & 25 & 15 & 33 \\
\hline $21 / 9 / 2005$ & 29 & 58 & 34 & 9 & 8 & 24 \\
\hline $28 / 9 / 2005$ & 36 & 67 & 13 & 10 & 3 & 24 \\
\hline $10 / 10 / 2005$ & 48 & 70 & 16 & 32 & 5 & 63 \\
\hline $19 / 10 / 2005$ & 57 & 53 & 13 & 13 & 15 & 30 \\
\hline $26 / 10 / 2005$ & 64 & 102 & 12 & 12 & 6 & 44 \\
\hline $9 / 11 / 2005$ & 78 & 72 & 25 & 15 & 8 & 34 \\
\hline $16 / 11 / 2005$ & 85 & 80 & 24 & 22 & 10 & 35 \\
\hline $30 / 11 / 2005$ & 99 & 58 & 27 & 32 & 17 & - \\
\hline $7 / 12 / 2005$ & 106 & 97 & 26 & 25 & 30 & - \\
\hline $13 / 12 / 2005$ & 112 & 95 & 19 & 15 & 12 & - \\
\hline \multicolumn{2}{|c|}{ Média } & 73 & 20 & 18 & 10 & 35 \\
\hline
\end{tabular}

Tabela A 4 - Eficiência de remoção de turbidez nos filtros percoladores (\%)

\begin{tabular}{|c|c|c|c|c|c|}
\hline Data & Tempo (dias) & F1 & F2 & F3 & F4 \\
\hline $24 / 8 / 2005$ & 1 & 52 & 75 & 83 & 44 \\
\hline $31 / 8 / 2005$ & 8 & 91 & 88 & 96 & 69 \\
\hline $8 / 9 / 2005$ & 16 & 73 & 45 & 92 & 0 \\
\hline $14 / 9 / 2005$ & 22 & 71 & 73 & 84 & 63 \\
\hline $21 / 9 / 2005$ & 29 & 42 & 85 & 87 & 59 \\
\hline $28 / 9 / 2005$ & 36 & 80 & 85 & 95 & 64 \\
\hline $10 / 10 / 2005$ & 48 & 77 & 54 & 93 & 10 \\
\hline $19 / 10 / 2005$ & 57 & 75 & 75 & 71 & 43 \\
\hline $26 / 10 / 2005$ & 64 & 88 & 88 & 95 & 57 \\
\hline $9 / 11 / 2005$ & 78 & 65 & 79 & 89 & 53 \\
\hline $16 / 11 / 2005$ & 85 & 70 & 73 & 88 & 56 \\
\hline $30 / 11 / 2005$ & 99 & 54 & 45 & 70 & - \\
\hline $7 / 12 / 2005$ & 106 & 73 & 74 & 69 & - \\
\hline $13 / 12 / 2005$ & 112 & 81 & 84 & 87 & - \\
\hline \multicolumn{2}{|c|}{ Média } & 71 & 73 & 86 & 47 \\
\hline
\end{tabular}

Tabela A 5 - Alcalinidade Total do esgoto sanitário afluente e efluente dos filtros percoladores $\left(\mathrm{mg} \mathrm{CaCo}_{3} / \mathrm{L}\right)$

\begin{tabular}{|c|c|c|c|c|c|c|}
\hline Data & Tempo (dias) & AFL & F1 & F2 & F3 & F4 \\
\hline $24 / 8 / 2005$ & 1 & 129,72 & 127,65 & 4,14 & 17,94 & 9,43 \\
\hline $31 / 8 / 2005$ & 8 & 169,99 & 101,23 & 187,18 & 158,53 & 173,81 \\
\hline $8 / 9 / 2005$ & 16 & 140,99 & 104,65 & 131,56 & 31,28 & 140,99 \\
\hline $14 / 9 / 2005$ & 22 & 139,38 & 114,31 & 132,48 & 12,19 & 147,20 \\
\hline $21 / 9 / 2005$ & 29 & 146,51 & 141,45 & 155,25 & 39,79 & 163,30 \\
\hline $28 / 9 / 2005$ & 36 & 182,62 & 120,52 & 135,93 & 22,54 & 168,36 \\
\hline $10 / 10 / 2005$ & 48 & 158,60 & 71,76 & 138,00 & 5,06 & 139,38 \\
\hline $19 / 10 / 2005$ & 57 & 201,94 & 113,85 & 172,27 & 3,22 & 172,50 \\
\hline $26 / 10 / 2005$ & 64 & 150,19 & 58,88 & 65,55 & 3,91 & 91,54 \\
\hline $9 / 11 / 2005$ & 78 & 131,10 & 59,80 & 73,60 & 5,06 & 103,50 \\
\hline $16 / 11 / 2005$ & 85 & 158,70 & 87,40 & 94,30 & 32,20 & 110,40 \\
\hline $30 / 11 / 2005$ & 99 & 151,34 & 62,10 & 64,40 & 18,40 & - \\
\hline $7 / 12 / 2005$ & 106 & 121,44 & 67,85 & 66,70 & 20,70 & - \\
\hline $13 / 12 / 2005$ & 112 & 200,00 & 76,00 & 78,00 & 10,00 & - \\
\hline \multicolumn{2}{|c|}{ Média } & 155,89 & 93,39 & 107,10 & 27,20 & 129,13 \\
\hline
\end{tabular}


Tabela A 6 - Concentração de NTK do esgoto sanitário afluente e efluente dos filtros percoladores $(\mathrm{mg} / \mathrm{L})$

\begin{tabular}{|c|c|c|c|c|c|c|}
\hline Data & Tempo (dias) & $\overline{A F L}$ & F1 & F2 & F3 & F4 \\
\hline $24 / 8 / 2005$ & 1 & 38,20 & 37,13 & 33,92 & 33,92 & 46,76 \\
\hline $31 / 8 / 2005$ & 8 & 46,76 & 32,85 & 55,32 & 43,55 & 42,48 \\
\hline $8 / 9 / 2005$ & 16 & 33,92 & 31,78 & 28,58 & 12,53 & 36,06 \\
\hline $14 / 9 / 2005$ & 22 & 30,71 & 27,51 & 27,51 & 14,67 & 27,51 \\
\hline $21 / 9 / 2005$ & 29 & 51,04 & 27,51 & 25,37 & 13,60 & 40,34 \\
\hline $28 / 9 / 2005$ & 36 & 37,13 & 23,23 & 28,58 & 16,81 & 40,34 \\
\hline $10 / 10 / 2005$ & 48 & 40,34 & 18,95 & 42,48 & 17,88 & 33,92 \\
\hline 19/10/2005 & 57 & 30,71 & 15,74 & 24,30 & 6,11 & 27,51 \\
\hline $26 / 10 / 2005$ & 64 & 22,16 & 15,74 & 3,97 & 0,00 & 17,88 \\
\hline 9/11/2005 & 78 & 33,92 & 18,95 & 10,39 & 0,00 & 18,95 \\
\hline $16 / 11 / 2005$ & 85 & 30,71 & 21,09 & 8,25 & 0,00 & 21,09 \\
\hline $30 / 11 / 2005$ & 99 & 30,71 & 14,67 & 9,32 & 0,00 & - \\
\hline $7 / 12 / 2005$ & 106 & 28,58 & 11,46 & 8,25 & 0,00 & - \\
\hline $13 / 12 / 2005$ & 112 & 51,04 & 8,25 & 12,53 & 0,00 & 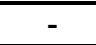 \\
\hline \multicolumn{2}{|c|}{ Média (a partir do $64^{\circ}$ dia) } & 32,85 & 15,03 & 8,79 & 0,00 & 19,31 \\
\hline \multicolumn{2}{|c|}{ Média (112 dias) } & 36,14 & 21,78 & 22,77 & 11,36 & 32,08 \\
\hline
\end{tabular}

Tabela A 7 - Eficiência de remoção de NTK nos filtros percoladores (\%)

\begin{tabular}{|c|c|c|c|c|c|}
\hline Data & Tempo (dias) & F1 & F2 & F3 & F4 \\
\hline $24 / 8 / 2005$ & 1 & 3 & 11 & 11 & 0 \\
\hline $31 / 8 / 2005$ & 8 & 30 & 0 & 7 & 9 \\
\hline $8 / 9 / 2005$ & 16 & 6 & 16 & 63 & 0 \\
\hline $14 / 9 / 2005$ & 22 & 10 & 10 & 52 & 10 \\
\hline $21 / 9 / 2005$ & 29 & 46 & 50 & 73 & 21 \\
\hline $28 / 9 / 2005$ & 36 & 37 & 23 & 55 & 0 \\
\hline $10 / 10 / 2005$ & 48 & 53 & 0 & 56 & 16 \\
\hline $19 / 10 / 2005$ & 57 & 49 & 21 & 80 & 10 \\
\hline $26 / 10 / 2005$ & 64 & 29 & 82 & 100 & 19 \\
\hline $9 / 11 / 2005$ & 78 & 44 & 69 & 100 & 44 \\
\hline $16 / 11 / 2005$ & 85 & 31 & 73 & 100 & 31 \\
\hline $30 / 11 / 2005$ & 99 & 52 & 70 & 100 & - \\
\hline $7 / 12 / 2005$ & 106 & 60 & 71 & 100 & - \\
\hline $13 / 12 / 2005$ & 112 & 84 & 75 & 100 & - \\
\hline Média (a partir do 64 ${ }^{\circ}$ dia) & 50 & 73 & 100 & 32 \\
\hline \multicolumn{2}{|c|}{ Média (112 dias) } & 38 & 41 & 71 & 15 \\
\hline
\end{tabular}


Tabela A 8 - Concentração de nitrogênio amoniacal (mg/L)

\begin{tabular}{|c|c|c|c|c|c|c|}
\hline Data & Tempo (dias) & AFL & F1 & F2 & F3 & F4 \\
\hline $24 / 8 / 2005$ & 1 & 16,52 & 17,32 & 18,66 & 16,79 & 30,16 \\
\hline $31 / 8 / 2005$ & 8 & 32,56 & 15,99 & 32,83 & 33,37 & 33,10 \\
\hline $8 / 9 / 2005$ & 16 & 27,22 & 22,40 & 23,21 & 6,89 & 23,74 \\
\hline $14 / 9 / 2005$ & 22 & 20,00 & 15,45 & 18,66 & 4,22 & 21,60 \\
\hline $21 / 9 / 2005$ & 29 & 24,81 & 21,60 & 24,81 & 13,04 & 26,41 \\
\hline $28 / 9 / 2005$ & 36 & 30,43 & 19,19 & 24,01 & 11,44 & 28,82 \\
\hline $10 / 10 / 2005$ & 48 & 27,22 & 17,06 & 25,88 & 12,51 & 29,09 \\
\hline $19 / 10 / 2005$ & 57 & 29,09 & 17,06 & 26,15 & 6,63 & 27,75 \\
\hline $26 / 10 / 2005$ & 64 & 22,40 & 13,04 & 4,22 & 0,00 & 16,79 \\
\hline $9 / 11 / 2005$ & 78 & 20,26 & 12,51 & 5,82 & 0,00 & 15,45 \\
\hline $16 / 11 / 2005$ & 85 & 28,55 & 13,58 & 5,02 & 0,00 & 17,06 \\
\hline $30 / 11 / 2005$ & 99 & 26,95 & 13,04 & 6,36 & 0,00 & - \\
\hline $7 / 12 / 2005$ & 106 & 18,66 & 11,44 & 4,49 & 0,00 & - \\
\hline $13 / 12 / 2005$ & 112 & 31,23 & 10,37 & 4,22 & 0,00 & - \\
\hline Média (a partir do 64 ${ }^{\text {dia) }}$ & 24,68 & 12,33 & 5,02 & 0,00 & 16,43 \\
\hline \multicolumn{2}{|c|}{ Média (112 dias) } & 25,42 & 15,72 & 16,02 & 7,49 & 24,54 \\
\hline
\end{tabular}

Tabela A 9 - Eficiência de remoção de nitrogênio amoniacal (\%)

\begin{tabular}{|c|c|c|c|c|c|}
\hline Data & Tempo (dias) & F1 & F2 & F3 & F4 \\
\hline $24 / 08 / 05$ & 1 & 0 & 0 & 0 & 0 \\
\hline $31 / 08 / 05$ & 8 & 51 & 0 & 0 & 0 \\
\hline $08 / 09 / 05$ & 16 & 18 & 15 & 75 & 0 \\
\hline $14 / 09 / 05$ & 22 & 23 & 7 & 79 & 0 \\
\hline $21 / 09 / 05$ & 29 & 13 & 0 & 47 & 0 \\
\hline $28 / 09 / 05$ & 36 & 37 & 21 & 62 & 5 \\
\hline $10 / 10 / 05$ & 48 & 37 & 5 & 54 & 0 \\
\hline $19 / 10 / 05$ & 57 & 41 & 10 & 77 & 5 \\
\hline $26 / 10 / 05$ & 64 & 42 & 81 & 100 & 25 \\
\hline $09 / 11 / 05$ & 78 & 38 & 71 & 100 & 24 \\
\hline $16 / 11 / 05$ & 85 & 52 & 82 & 100 & 40 \\
\hline $30 / 11 / 05$ & 99 & 52 & 76 & 100 & - \\
\hline $07 / 12 / 05$ & 106 & 39 & 76 & 100 & - \\
\hline $13 / 12 / 05$ & 112 & 67 & 86 & 100 & - \\
\hline Média (a partir do 64 ${ }^{\circ}$ dia) & 48 & 79 & 100 & 30 \\
\hline \multicolumn{2}{|c|}{ Média (112 dias) } & 36 & 38 & 71 & 9 \\
\hline
\end{tabular}


Tabela A 10 - Concentração de nitrato do esgoto sanitário afluente e efluente dos filtros percoladores $(\mathrm{mg} / \mathrm{L})$

\begin{tabular}{|c|c|c|c|c|c|c|}
\hline Data & Tempo (dias) & AFL & $\overline{F 1}$ & F2 & F3 & F4 \\
\hline $24 / 8 / 2005$ & 1 & 2,46 & 1,85 & 0,58 & 1,32 & 0,57 \\
\hline $31 / 8 / 2005$ & 8 & 2,08 & 3,40 & 1,03 & 0,50 & 1,42 \\
\hline $8 / 9 / 2005$ & 16 & 1,52 & 0,93 & 1,07 & 4,41 & 0,77 \\
\hline $14 / 9 / 2005$ & 22 & 2,49 & 2,00 & 1,11 & 5,74 & 1,09 \\
\hline $21 / 9 / 2005$ & 29 & 2,06 & 2,28 & 1,36 & 5,17 & 0,77 \\
\hline $28 / 9 / 2005$ & 36 & 1,37 & 4,22 & 1,43 & 11,44 & 0,88 \\
\hline $10 / 10 / 2005$ & 48 & 1,58 & 6,81 & 0,82 & 11,80 & 0,52 \\
\hline $19 / 10 / 2005$ & 57 & 2,13 & 7,19 & 2,18 & 19,01 & 1,76 \\
\hline $26 / 10 / 2005$ & 64 & 1,62 & 12,03 & 13,54 & 15,17 & 4,59 \\
\hline $9 / 11 / 2005$ & 78 & 1,57 & 11,87 & 15,67 & 16,07 & 5,21 \\
\hline $16 / 11 / 2005$ & 85 & 1,63 & 17,24 & 18,19 & 25,60 & 2,36 \\
\hline $30 / 11 / 2005$ & 99 & 1,44 & 18,92 & 19,86 & 27,77 & - \\
\hline $7 / 12 / 2005$ & 106 & 1,06 & 20,55 & 22,31 & 24,02 & - \\
\hline $13 / 12 / 2005$ & 112 & 3,04 & 20,32 & 22,02 & 27,25 & - \\
\hline \multicolumn{2}{|c|}{ Média (a partir do $64^{\circ}$ dia) } & 1,73 & 16,82 & 18,60 & 22,65 & 4,05 \\
\hline \multicolumn{2}{|c|}{ Média (112 dias) } & 1,86 & 9,26 & 8,65 & 13,95 & 1,81 \\
\hline
\end{tabular}

Tabela A 11 - Concentração de nitrito do esgoto sanitário afluente e efluente dos filtros percoladores $(\mathrm{mg} / \mathrm{L})$

\begin{tabular}{|c|c|c|c|c|c|c|}
\hline Data & Tempo (dias) & AFL & F1 & $\mathbf{F 2}$ & F3 & F4 \\
\hline $24 / 8 / 2005$ & 1 & 0,0000 & 0,9650 & 0,0084 & 0,0048 & 0,0101 \\
\hline $31 / 8 / 2005$ & 8 & 0,0079 & 6,9700 & 0,0587 & 0,1934 & 0,0072 \\
\hline $8 / 9 / 2005$ & 16 & 0,0113 & 4,3200 & 0,0207 & 13,3500 & 0,0140 \\
\hline $14 / 9 / 2005$ & 22 & 0,0131 & 1,7800 & 4,6250 & 14,4750 & 0,0922 \\
\hline $21 / 9 / 2005$ & 29 & 0,0000 & 1,3200 & 1,6525 & 9,9200 & 0,0730 \\
\hline $28 / 9 / 2005$ & 36 & 0,0000 & 2,9200 & 2,2450 & 7,5600 & 0,2670 \\
\hline 10/10/2005 & 48 & 0,0061 & 1,8800 & 0,0469 & 0,0162 & 0,0620 \\
\hline 19/10/2005 & 57 & 0,0000 & 1,0000 & 0,1200 & 0,0414 & 0,7310 \\
\hline $26 / 10 / 2005$ & 64 & 0,0000 & 0,3000 & 1,1400 & 0,0178 & 3,1850 \\
\hline $9 / 11 / 2005$ & 78 & 0,0000 & 1,2300 & 0,0000 & 0,0000 & 0,0693 \\
\hline $16 / 11 / 2005$ & 85 & 0,0000 & 0,7690 & 0,0000 & 0,0000 & 0,5200 \\
\hline $30 / 11 / 2005$ & 99 & 0,0000 & 0,7150 & 0,0035 & 0,2070 & - \\
\hline $7 / 12 / 2005$ & 106 & 0,0000 & 0,4825 & 0,0016 & 0,0034 & - \\
\hline 13/12/2005 & 112 & 0,0000 & 0,5875 & 0,0022 & 0,0021 & - \\
\hline \multicolumn{2}{|c|}{ Média (a partir do $64^{\circ} \mathrm{dia}$ ) } & 0,00 & 0,68 & 0,19 & 0,04 & 1,26 \\
\hline \multicolumn{2}{|c|}{ Média (112 dias) } & 0,00 & 1,80 & 0,71 & 3,27 & 0,46 \\
\hline
\end{tabular}


Tabela A 12 - Concentração de DQO total do esgoto sanitário afluente e efluente dos filtros percoladores (mg/L)

\begin{tabular}{|c|c|c|c|c|c|c|}
\hline Data & Tempo (dias) & AFL & F1 & F2 & F3 & F4 \\
\hline $24 / 8 / 2005$ & 1 & 200,4 & 128,8 & 130,0 & 65,4 & 190,5 \\
\hline $31 / 8 / 2005$ & 8 & 240,7 & 125,4 & 119,9 & 47,7 & 208,9 \\
\hline $8 / 9 / 2005$ & 16 & 101,1 & 69,2 & 100,5 & 38,9 & 110,1 \\
\hline $14 / 9 / 2005$ & 22 & 193,7 & 180,9 & 113,9 & 86,5 & 156,7 \\
\hline $21 / 9 / 2005$ & 29 & 211,1 & 153,1 & 103,3 & 95,3 & 146,6 \\
\hline $28 / 9 / 2005$ & 36 & 124,2 & 55,1 & 40,0 & 15,3 & 92,7 \\
\hline $10 / 10 / 2005$ & 48 & 181,5 & 75,3 & 122,5 & 46,3 & 196,2 \\
\hline $19 / 10 / 2005$ & 57 & 180,7 & 74,5 & 80,1 & 37,4 & 109,7 \\
\hline $26 / 10 / 2005$ & 64 & 194,8 & 65,2 & 34,4 & 40,0 & 84,1 \\
\hline $9 / 11 / 2005$ & 78 & 221,6 & 86,7 & 62,9 & 45,1 & 185,5 \\
\hline $16 / 11 / 2005$ & 85 & 212,9 & 82,5 & 103,2 & 79,3 & 165,8 \\
\hline $30 / 11 / 2005$ & 99 & 230,4 & 98,4 & 77,0 & 92,7 & - \\
\hline $7 / 12 / 2005$ & 106 & 194,4 & 82,6 & 68,6 & 41,1 & - \\
\hline $13 / 12 / 2005$ & 112 & 327,6 & 119,0 & 130,4 & 105,0 & - \\
\hline \multicolumn{2}{|c|}{ Média } & 201,1 & 99,7 & 91,9 & 59,7 & 149,7 \\
\hline
\end{tabular}

Tabela A 13 - Eficiência de remoção de DQO total do esgoto sanitário afluente e efluente dos filtros percoladores (\%)

\begin{tabular}{|c|c|c|c|c|c|}
\hline Data & Tempo (dias) & F1 & F2 & F3 & F4 \\
\hline $24 / 8 / 2005$ & 1 & 36 & 35 & 67 & 5 \\
\hline $31 / 8 / 2005$ & 8 & 48 & 50 & 80 & 13 \\
\hline $8 / 9 / 2005$ & 16 & 32 & 1 & 62 & 0 \\
\hline $14 / 9 / 2005$ & 22 & 7 & 41 & 55 & 19 \\
\hline $21 / 9 / 2005$ & 29 & 27 & 51 & 55 & 31 \\
\hline $28 / 9 / 2005$ & 36 & 56 & 68 & 88 & 25 \\
\hline $10 / 10 / 2005$ & 48 & 59 & 33 & 75 & 0 \\
\hline $19 / 10 / 2005$ & 57 & 59 & 56 & 79 & 39 \\
\hline $26 / 10 / 2005$ & 64 & 67 & 82 & 79 & 57 \\
\hline $9 / 11 / 2005$ & 78 & 61 & 72 & 80 & 16 \\
\hline $16 / 11 / 2005$ & 85 & 61 & 52 & 63 & 22 \\
\hline $30 / 11 / 2005$ & 99 & 57 & 67 & 60 & - \\
\hline $7 / 12 / 2005$ & 106 & 58 & 65 & 79 & - \\
\hline $13 / 12 / 2005$ & 112 & 64 & 60 & 68 & - \\
\hline \multicolumn{2}{|c|}{ Média } & 49 & 52 & 71 & 21 \\
\hline
\end{tabular}


Tabela A 14 - Concentração de DQO filtrada do esgoto sanitário afluente e efluente dos filtros percoladores $(\mathrm{mg} / \mathrm{L})$

\begin{tabular}{|c|c|c|c|c|c|c|}
\hline Data & Tempo (dias) & AFL & F1 & F2 & F3 & F4 \\
\hline $24 / 8 / 2005$ & 1 & 145,2 & 72,3 & 77,3 & 33,5 & 117,4 \\
\hline $31 / 8 / 2005$ & 8 & 160,4 & 64,4 & 52,5 & 25,9 & 121,0 \\
\hline $8 / 9 / 2005$ & 16 & 97,7 & 62,2 & 52,8 & 28,5 & 62,0 \\
\hline $14 / 9 / 2005$ & 22 & 123,5 & 77,4 & 73,6 & 81,7 & 105,9 \\
\hline $21 / 9 / 2005$ & 29 & 134,5 & 114,6 & 76,4 & 78,2 & 108,8 \\
\hline $28 / 9 / 2005$ & 36 & 95,6 & 58,3 & 52,4 & 37,3 & 65,5 \\
\hline $10 / 10 / 2005$ & 48 & 124,1 & 61,2 & 78,8 & 36,7 & 112,0 \\
\hline $19 / 10 / 2005$ & 57 & 141,5 & 56,0 & 53,0 & 34,7 & 81,8 \\
\hline $26 / 10 / 2005$ & 64 & 155,5 & 57,4 & 28,9 & 19,4 & 48,5 \\
\hline $9 / 11 / 2005$ & 78 & 168,1 & 87,5 & 40,3 & 35,8 & 110,4 \\
\hline $16 / 11 / 2005$ & 85 & 130,9 & 88,6 & 72,6 & 41,7 & 76,1 \\
\hline $30 / 11 / 2005$ & 99 & 155,8 & 79,9 & 85,5 & 89,0 & - \\
\hline $7 / 12 / 2005$ & 106 & 156,4 & 35,6 & 34,6 & 28,2 & - \\
\hline $13 / 12 / 2005$ & 112 & 159,6 & 64,5 & 30,0 & 24,6 & - \\
\hline \multicolumn{2}{|c|}{ Média } & 139,2 & 70,0 & 57,7 & 42,5 & 91,7 \\
\hline
\end{tabular}

Tabela A 15 - Eficiência de remoção de DQO filtrada do esgoto sanitário afluente e efluente dos filtros percoladores (\%)

\begin{tabular}{|c|c|c|c|c|c|}
\hline Data & Tempo (dias) & F1 & F2 & F3 & F4 \\
\hline $24 / 8 / 2005$ & 1 & 50 & 47 & 77 & 19 \\
\hline $31 / 8 / 2005$ & 8 & 60 & 67 & 84 & 25 \\
\hline $8 / 9 / 2005$ & 16 & 36 & 46 & 71 & 37 \\
\hline $14 / 9 / 2005$ & 22 & 37 & 40 & 34 & 14 \\
\hline $21 / 9 / 2005$ & 29 & 15 & 43 & 42 & 19 \\
\hline $28 / 9 / 2005$ & 36 & 39 & 45 & 61 & 31 \\
\hline $10 / 10 / 2005$ & 48 & 51 & 36 & 70 & 10 \\
\hline $19 / 10 / 2005$ & 57 & 60 & 63 & 76 & 42 \\
\hline $26 / 10 / 2005$ & 64 & 63 & 81 & 88 & 69 \\
\hline $9 / 11 / 2005$ & 78 & 48 & 76 & 79 & 34 \\
\hline $16 / 11 / 2005$ & 85 & 32 & 45 & 68 & 42 \\
\hline $30 / 11 / 2005$ & 99 & 49 & 45 & 43 & - \\
\hline $7 / 12 / 2005$ & 106 & 77 & 78 & 82 & - \\
\hline $13 / 12 / 2005$ & 112 & 60 & 81 & 85 & - \\
\hline \multicolumn{2}{|c|}{ Média } & 48 & 57 & 68 & 31 \\
\hline
\end{tabular}

Tabela A 16 - Concentração de $\mathrm{DBO}_{5}$ do esgoto sanitário afluente e efluente dos filtros percoladores $(\mathrm{mg} / \mathrm{L})$

\begin{tabular}{|c|c|c|c|c|c|c|}
\hline Data & Tempo (dias) & AFL & F1 & F2 & F3 & F4 \\
\hline $24 / 8 / 2005$ & 1 & 45 & 30 & 7 & 5 & 10 \\
\hline $8 / 9 / 2005$ & 16 & 79 & 49 & 51 & 23 & 74 \\
\hline $28 / 9 / 2005$ & 36 & 135 & 64 & 25 & 16 & 55 \\
\hline $19 / 10 / 2005$ & 57 & 75 & 42 & 45 & 20 & 42 \\
\hline $9 / 11 / 2005$ & 78 & 179 & 30 & 110 & 88 & 70 \\
\hline $30 / 11 / 2005$ & 99 & 190 & 78 & 78 & 102 & - \\
\hline $13 / 12 / 2005$ & 112 & 250 & 150 & 145 & 125 & - \\
\hline \multicolumn{2}{|c|}{ Média } & 136,1 & 63,3 & 65,9 & 54,1 & 50,2 \\
\hline
\end{tabular}


Tabela A 17 - Eficiência de remoção de $\mathrm{DBO}_{5}$ do esgoto sanitário afluente e efluente dos filtros percoladores (\%)

\begin{tabular}{|c|c|c|c|c|c|}
\hline Data & Tempo (dias) & F1 & F2 & F3 & F4 \\
\hline $24 / 8 / 2005$ & 1 & 33 & 84 & 89 & 78 \\
\hline $8 / 9 / 2005$ & 16 & 38 & 35 & 71 & 6 \\
\hline $28 / 9 / 2005$ & 36 & 53 & 81 & 88 & 59 \\
\hline $19 / 10 / 2005$ & 57 & 44 & 40 & 73 & 44 \\
\hline $9 / 11 / 2005$ & 78 & 83 & 39 & 51 & 61 \\
\hline $30 / 11 / 2005$ & 99 & 59 & 59 & 46 & - \\
\hline $13 / 12 / 2005$ & 112 & 40 & 42 & 50 & - \\
\hline \multicolumn{2}{|c|}{ Média } & 50 & 54 & 67 & 50 \\
\hline
\end{tabular}

Tabela A 18 - Número mais provável de coliformes totais do esgoto sanitário afluente e efluente dos filtros percoladores (NMP/100 ml)

\begin{tabular}{|c|c|c|c|c|c|c|}
\hline Data & Tempo (dias) & AFL & F1 & F2 & F3 & F4 \\
\hline $24 / 8 / 2005$ & 1 & $3,0 \mathrm{E}+09$ & $1,4 \mathrm{E}+06$ & $2,0 \mathrm{E}+02$ & $3,2 \mathrm{E}+06$ & $4,0 \mathrm{E}+04$ \\
\hline $8 / 9 / 2005$ & 16 & $1,0 \mathrm{E}+07$ & $1,0 \mathrm{E}+05$ & $7,0 \mathrm{E}+03$ & $2,2 \mathrm{E}+04$ & $4,0 \mathrm{E}+05$ \\
\hline $21 / 9 / 2005$ & 29 & $5,0 \mathrm{E}+08$ & $2,3 \mathrm{E}+07$ & $2,5 \mathrm{E}+05$ & $2,0 \mathrm{E}+05$ & $2,6 \mathrm{E}+06$ \\
\hline $10 / 10 / 2005$ & 48 & $9,7 \mathrm{E}+08$ & $1,8 \mathrm{E}+07$ & $7,0 \mathrm{E}+06$ & $1,0 \mathrm{E}+05$ & $1,2 \mathrm{E}+07$ \\
\hline $16 / 11 / 2005$ & 85 & $2,5 \mathrm{E}+07$ & $4,0 \mathrm{E}+05$ & $5,0 \mathrm{E}+06$ & $4,0 \mathrm{E}+06$ & $1,0 \mathrm{E}+07$ \\
\hline $7 / 12 / 2005$ & 106 & $3,0 \mathrm{E}+08$ & $2,0 \mathrm{E}+07$ & $3,0 \mathrm{E}+07$ & $1,0 \mathrm{E}+06$ & $1,0 \mathrm{E}+08$ \\
\hline \multicolumn{2}{|c|}{ Média } & $8,01 \mathrm{E}+08$ & $1,05 \mathrm{E}+07$ & $7,04 \mathrm{E}+06$ & $1,42 \mathrm{E}+06$ & $2,08 \mathrm{E}+07$ \\
\hline
\end{tabular}

Tabela A 19 - Eficiência de remoção de coliformes totais do esgoto sanitário afluente e efluente dos filtros percoladores (\%)

\begin{tabular}{|c|c|c|c|c|c|}
\hline Data & Tempo (dias) & F1 & F2 & F3 & F4 \\
\hline $24 / 8 / 2005$ & 1 & 100 & 100 & 100 & 100 \\
\hline $8 / 9 / 2005$ & 16 & 99 & 100 & 100 & 96 \\
\hline $21 / 9 / 2005$ & 29 & 95 & 100 & 100 & 99 \\
\hline $10 / 10 / 2005$ & 48 & 98 & 99 & 100 & 99 \\
\hline $16 / 11 / 2005$ & 85 & 98 & 80 & 84 & 60 \\
\hline $7 / 12 / 2005$ & 106 & 93 & 90 & 100 & 67 \\
\hline \multicolumn{2}{|r|}{ Média } & 97 & 95 & 97 & 87 \\
\hline
\end{tabular}

Tabela A 20 - Número mais provável de coliformes fecais do esgoto sanitário afluente e efluente dos filtros percoladores (NMP/100 ml)

\begin{tabular}{|c|c|c|c|c|c|c|}
\hline Data & Tempo (dias) & $\overline{\mathrm{AFL}}$ & F1 & F2 & F3 & F4 \\
\hline $24 / 8 / 2005$ & 1 & $2,0 \mathrm{E}+09$ & $1,4 \mathrm{E}+06$ & $1,0 \mathrm{E}+02$ & $1,1 \mathrm{E}+06$ & $4,0 \mathrm{E}+03$ \\
\hline $8 / 9 / 2005$ & 16 & $3,0 \mathrm{E}+07$ & $3,0 \mathrm{E}+05$ & $3,6 \mathrm{E}+04$ & $6,0 \mathrm{E}+03$ & $3,0 \mathrm{E}+05$ \\
\hline $21 / 9 / 2005$ & 29 & $5,0 \mathrm{E}+08$ & $1,8 \mathrm{E}+07$ & $3,5 \mathrm{E}+05$ & $1,5 \mathrm{E}+05$ & $2,8 \mathrm{E}+06$ \\
\hline $10 / 10 / 2005$ & 48 & $5,9 \mathrm{E}+08$ & $4,0 \mathrm{E}+06$ & $3,8 \mathrm{E}+06$ & $1,0 \mathrm{E}+05$ & $7,5 \mathrm{E}+06$ \\
\hline $16 / 11 / 2005$ & 85 & $4,0 \mathrm{E}+06$ & $2,1 \mathrm{E}+05$ & $2,1 \mathrm{E}+06$ & $1,2 \mathrm{E}+06$ & $3,0 \mathrm{E}+06$ \\
\hline $7 / 12 / 2005$ & 106 & $3,0 \mathrm{E}+07$ & $2,0 \mathrm{E}+07$ & $1,0 \mathrm{E}+06$ & $2,0 \mathrm{E}+06$ & $2,0 \mathrm{E}+07$ \\
\hline \multicolumn{2}{|c|}{ Média } & $5,17 \mathrm{E}+08$ & $7,23 \mathrm{E}+06$ & $1,21 \mathrm{E}+06$ & $7,59 \mathrm{E}+05$ & $5,60 \mathrm{E}+06$ \\
\hline
\end{tabular}


Tabela A 21 - Eficiência de remoção de coliformes fecais do esgoto sanitário afluente e efluente dos filtros percoladores (\%)

\begin{tabular}{|c|c|c|c|c|c|}
\hline Data & Tempo (dias) & F1 & F2 & F3 & F4 \\
\hline $24 / 8 / 2005$ & 1 & 100 & 100 & 100 & 100 \\
\hline $8 / 9 / 2005$ & 16 & 99 & 100 & 100 & 99 \\
\hline $21 / 9 / 2005$ & 29 & 97 & 100 & 100 & 99 \\
\hline $10 / 10 / 2005$ & 48 & 99 & 99 & 100 & 99 \\
\hline $16 / 11 / 2005$ & 85 & 95 & 48 & 70 & 25 \\
\hline $7 / 12 / 2005$ & 106 & 33 & 97 & 93 & 33 \\
\hline \multicolumn{2}{|c|}{ Média } & 87 & 91 & 94 & 76 \\
\hline
\end{tabular}

Tabela A 22 - Concentração de sólidos totais do esgoto sanitário afluente e efuente dos filtros percoladores $(\mathrm{g} / \mathrm{L})$

\begin{tabular}{|c|c|c|c|c|c|c|}
\hline Data & Tempo (dias) & AFL & F1 & F2 & F3 & F4 \\
\hline $24 / 8 / 2005$ & 1 & 0,286 & 0,286 & 0,261 & 0,221 & 0,341 \\
\hline $31 / 8 / 2005$ & 8 & 0,310 & 0,280 & 0,266 & 0,220 & 0,327 \\
\hline $8 / 9 / 2005$ & 16 & 0,340 & 0,330 & 0,321 & 0,251 & 0,290 \\
\hline $14 / 9 / 2005$ & 22 & 0,235 & 0,614 & 0,230 & 0,270 & 0,272 \\
\hline $21 / 9 / 2005$ & 29 & 0,206 & 0,227 & 0,124 & 0,116 & 0,189 \\
\hline $28 / 9 / 2005$ & 36 & 0,385 & 0,296 & 0,248 & 0,274 & 0,298 \\
\hline $10 / 10 / 2005$ & 48 & 0,232 & 0,233 & 0,321 & 0,197 & 0,243 \\
\hline $19 / 10 / 2005$ & 57 & 0,275 & 0,283 & 0,225 & 0,312 & 0,269 \\
\hline $26 / 10 / 2005$ & 64 & 0,283 & 0,290 & 0,166 & 0,189 & 0,215 \\
\hline $9 / 11 / 2005$ & 78 & 0,324 & 0,244 & 0,261 & 0,303 & 0,266 \\
\hline $16 / 11 / 2005$ & 85 & 0,347 & 0,493 & 0,311 & 0,394 & 0,296 \\
\hline $30 / 11 / 2005$ & 99 & 0,286 & 0,247 & 0,324 & 0,233 & - \\
\hline $7 / 12 / 2005$ & 106 & 0,250 & 0,196 & 0,236 & 0,204 & - \\
\hline \multicolumn{2}{|c|}{ Média } & 0,289 & 0,309 & 0,253 & 0,245 & 0,273 \\
\hline
\end{tabular}

Tabela A 23 - Concentração de sólidos totais fixos do esgoto sanitário afluente e efluente dos filtros percoladores $(\mathrm{g} / \mathrm{L})$

\begin{tabular}{|c|c|c|c|c|c|c|}
\hline Data & Tempo (dias) & AFL & F1 & F2 & F3 & F4 \\
\hline $24 / 8 / 2005$ & 1 & 0,113 & 0,084 & 0,153 & 0,160 & 0,247 \\
\hline $31 / 8 / 2005$ & 8 & 0,112 & 0,148 & 0,068 & 0,040 & 0,143 \\
\hline $8 / 9 / 2005$ & 16 & 0,185 & 0,141 & 0,175 & 0,154 & 0,100 \\
\hline $14 / 9 / 2005$ & 22 & 0,158 & 0,398 & 0,131 & 0,102 & 0,158 \\
\hline $21 / 9 / 2005$ & 29 & 0,100 & 0,069 & 0,103 & 0,106 & 0,119 \\
\hline $28 / 9 / 2005$ & 36 & 0,126 & 0,250 & 0,235 & 0,247 & 0,173 \\
\hline $10 / 10 / 2005$ & 48 & 0,108 & 0,127 & 0,150 & 0,095 & 0,100 \\
\hline $19 / 10 / 2005$ & 57 & 0,109 & 0,125 & 0,009 & 0,112 & 0,113 \\
\hline $26 / 10 / 2005$ & 64 & 0,149 & 0,189 & 0,135 & 0,164 & 0,165 \\
\hline $9 / 11 / 2005$ & 78 & 0,037 & 0,137 & 0,129 & 0,167 & 0,154 \\
\hline $16 / 11 / 2005$ & 85 & 0,166 & 0,280 & 0,156 & 0,059 & 0,161 \\
\hline $30 / 11 / 2005$ & 99 & 0,117 & 0,134 & 0,066 & 0,114 & - \\
\hline $7 / 12 / 2005$ & 106 & 0,144 & 0,130 & 0,059 & 0,067 & - \\
\hline \multicolumn{2}{|c|}{ Média } & 0,125 & 0,170 & 0,121 & 0,122 & 0,148 \\
\hline
\end{tabular}


Tabela A 24 - Concentração de sólidos totais voláteis do esgoto sanitário afluente e efluente dos filtros percoladores $(\mathrm{g} / \mathrm{L})$

\begin{tabular}{|c|c|c|c|c|c|c|}
\hline Data & Tempo (dias) & AFL & F1 & F2 & F3 & F4 \\
\hline $24 / 8 / 2005$ & 1 & 0,173 & 0,202 & 0,108 & 0,061 & 0,094 \\
\hline $31 / 8 / 2005$ & 8 & 0,198 & 0,132 & 0,198 & 0,180 & 0,184 \\
\hline $8 / 9 / 2005$ & 16 & 0,155 & 0,189 & 0,146 & 0,097 & 0,190 \\
\hline $14 / 9 / 2005$ & 22 & 0,077 & 0,216 & 0,099 & 0,168 & 0,114 \\
\hline $21 / 9 / 2005$ & 29 & 0,106 & 0,158 & 0,021 & 0,010 & 0,070 \\
\hline $28 / 9 / 2005$ & 36 & 0,259 & 0,046 & 0,013 & 0,026 & 0,125 \\
\hline $10 / 10 / 2005$ & 48 & 0,123 & 0,107 & 0,171 & 0,102 & 0,143 \\
\hline $19 / 10 / 2005$ & 57 & 0,166 & 0,158 & 0,216 & 0,200 & 0,156 \\
\hline $26 / 10 / 2005$ & 64 & 0,134 & 0,101 & 0,031 & 0,025 & 0,050 \\
\hline $9 / 11 / 2005$ & 78 & 0,287 & 0,107 & 0,133 & 0,136 & 0,111 \\
\hline $16 / 11 / 2005$ & 85 & 0,181 & 0,213 & 0,156 & 0,336 & 0,134 \\
\hline $30 / 11 / 2005$ & 99 & 0,169 & 0,113 & 0,259 & 0,119 & - \\
\hline $7 / 12 / 2005$ & 106 & 0,106 & 0,066 & 0,177 & 0,137 & - \\
\hline \multicolumn{2}{|c|}{ Média } & 0,164 & 0,139 & 0,133 & 0,123 & 0,125 \\
\hline
\end{tabular}

Tabela A 25 - Concentração de sólidos suspensos totais do esgoto sanitário afluente e efluente dos filtros percoladores $(\mathrm{g} / \mathrm{L})$

\begin{tabular}{|c|c|c|c|c|c|c|}
\hline Data & Tempo (dias) & AFL & F1 & F2 & F3 & F4 \\
\hline $24 / 8 / 2005$ & 1 & 0,050 & 0,035 & 0,001 & 0,006 & 0,001 \\
\hline $31 / 8 / 2005$ & 8 & 0,028 & 0,012 & 0,016 & 0,005 & 0,028 \\
\hline $8 / 9 / 2005$ & 16 & 0,029 & 0,033 & 0,043 & 0,001 & 0,049 \\
\hline $14 / 9 / 2005$ & 22 & 0,050 & 0,304 & 0,025 & 0,015 & 0,037 \\
\hline $21 / 9 / 2005$ & 29 & 0,041 & 0,029 & 0,008 & 0,007 & 0,035 \\
\hline $28 / 9 / 2005$ & 36 & 0,034 & 0,024 & 0,017 & 0,009 & 0,032 \\
\hline $10 / 10 / 2005$ & 48 & 0,030 & 0,029 & 0,043 & 0,005 & 0,078 \\
\hline $19 / 10 / 2005$ & 57 & 0,026 & 0,027 & 0,009 & 0,015 & 0,024 \\
\hline $26 / 10 / 2005$ & 64 & 0,034 & 0,012 & 0,021 & 0,007 & 0,014 \\
\hline $9 / 11 / 2005$ & 78 & 0,028 & 0,012 & 0,033 & 0,026 & 0,023 \\
\hline $16 / 11 / 2005$ & 85 & 0,075 & 0,101 & 0,067 & 0,044 & 0,047 \\
\hline $30 / 11 / 2005$ & 99 & 0,031 & 0,024 & 0,034 & 0,016 & - \\
\hline $7 / 12 / 2005$ & 106 & 0,028 & 0,021 & 0,017 & 0,020 & - \\
\hline \multicolumn{2}{|c|}{ Média } & 0,037 & 0,051 & 0,026 & 0,014 & 0,033 \\
\hline
\end{tabular}

Tabela A 26 - Concentração de sólidos suspensos fixos do esgoto sanitário afluente e efluente dos filtros percoladores $(\mathrm{g} / \mathrm{L})$

\begin{tabular}{|c|c|c|c|c|c|c|}
\hline Data & Tempo (dias) & AFL & F1 & F2 & F3 & F4 \\
\hline $24 / 8 / 2005$ & 1 & 0,003 & 0,003 & 0,001 & 0,001 & 0,001 \\
\hline $31 / 8 / 2005$ & 8 & 0,001 & 0,000 & 0,000 & 0,000 & 0,001 \\
\hline $8 / 9 / 2005$ & 16 & 0,002 & 0,011 & 0,003 & 0,000 & 0,004 \\
\hline $14 / 9 / 2005$ & 22 & 0,008 & 0,170 & 0,002 & 0,002 & 0,003 \\
\hline $21 / 9 / 2005$ & 29 & 0,009 & 0,009 & 0,000 & 0,002 & 0,012 \\
\hline $28 / 9 / 2005$ & 36 & 0,001 & 0,010 & 0,003 & 0,004 & 0,003 \\
\hline $10 / 10 / 2005$ & 48 & 0,011 & 0,018 & 0,009 & 0,002 & 0,015 \\
\hline $19 / 10 / 2005$ & 57 & 0,004 & 0,013 & 0,001 & 0,008 & 0,006 \\
\hline $26 / 10 / 2005$ & 64 & 0,004 & 0,001 & 0,004 & 0,000 & 0,001 \\
\hline $9 / 11 / 2005$ & 78 & 0,007 & 0,002 & 0,008 & 0,002 & 0,000 \\
\hline $16 / 11 / 2005$ & 85 & 0,011 & 0,051 & 0,006 & 0,001 & 0,006 \\
\hline $30 / 11 / 2005$ & 99 & 0,013 & 0,011 & 0,005 & 0,002 & - \\
\hline $7 / 12 / 2005$ & 106 & 0,006 & 0,005 & 0,002 & 0,003 & - \\
\hline \multicolumn{2}{|c|}{ Média } & 0,006 & 0,023 & 0,003 & 0,002 & 0,005 \\
\hline
\end{tabular}


Tabela A 27 - Concentração de sólidos suspensos voláteis do esgoto sanitário afluente e efluente dos filtros percoladores $(\mathrm{g} / \mathrm{L}$ )

\begin{tabular}{|c|c|c|c|c|c|c|}
\hline Data & Tempo (dias) & AFL & F1 & F2 & F3 & F4 \\
\hline $24 / 8 / 2005$ & 1 & 0,047 & 0,032 & 0,001 & 0,005 & 0,000 \\
\hline $31 / 8 / 2005$ & 8 & 0,028 & 0,012 & 0,016 & 0,005 & 0,026 \\
\hline $8 / 9 / 2005$ & 16 & 0,027 & 0,022 & 0,040 & 0,001 & 0,045 \\
\hline $14 / 9 / 2005$ & 22 & 0,042 & 0,134 & 0,022 & 0,014 & 0,034 \\
\hline $21 / 9 / 2005$ & 29 & 0,032 & 0,020 & 0,007 & 0,005 & 0,023 \\
\hline $28 / 9 / 2005$ & 36 & 0,033 & 0,014 & 0,014 & 0,006 & 0,029 \\
\hline $10 / 10 / 2005$ & 48 & 0,019 & 0,012 & 0,034 & 0,004 & 0,063 \\
\hline $19 / 10 / 2005$ & 57 & 0,022 & 0,014 & 0,008 & 0,007 & 0,018 \\
\hline $26 / 10 / 2005$ & 64 & 0,030 & 0,011 & 0,017 & 0,007 & 0,013 \\
\hline $9 / 11 / 2005$ & 78 & 0,021 & 0,009 & 0,026 & 0,024 & 0,022 \\
\hline $16 / 11 / 2005$ & 85 & 0,064 & 0,049 & 0,061 & 0,044 & 0,042 \\
\hline $30 / 11 / 2005$ & 99 & 0,018 & 0,012 & 0,029 & 0,013 & - \\
\hline $7 / 12 / 2005$ & 106 & 0,022 & 0,016 & 0,015 & 0,017 & - \\
\hline \multicolumn{2}{|c|}{ Média } & 0,031 & 0,027 & 0,022 & 0,012 & 0,029 \\
\hline
\end{tabular}

Tabela A 28 - Concentrações de cromo do esgoto sanitário afluente e efluente dos filtros percoladores $(\mathrm{mg} / \mathrm{L})$

\begin{tabular}{|c|c|c|c|c|c|c|}
\hline Data & Tempo (dias) & AFL & F1 & F2 & F3 & F4 \\
\hline $24 / 8 / 2005$ & 1 & 0,44 & 0,38 & 0,73 & 0,82 & 0,7 \\
\hline $31 / 8 / 2005$ & 8 & 0,2 & 0,12 & 0,5 & 0,37 & 0,31 \\
\hline $8 / 9 / 2005$ & 16 & 0,35 & 0,2 & 0,41 & 0,25 & 0,22 \\
\hline $14 / 9 / 2005$ & 22 & $\mathrm{ND}$ & $\mathrm{ND}$ & $\mathrm{ND}$ & 0,12 & $\mathrm{ND}$ \\
\hline $21 / 9 / 2005$ & 29 & $\mathrm{ND}$ & $\mathrm{ND}$ & 0,13 & 0,06 & 0,04 \\
\hline $28 / 9 / 2005$ & 36 & 0,06 & 0,07 & 0,06 & 0,09 & 0,18 \\
\hline $10 / 10 / 2005$ & 48 & 0,12 & 0,18 & 0,23 & 0,37 & 0,36 \\
\hline $19 / 10 / 2005$ & 57 & $\mathrm{ND}$ & $\mathrm{ND}$ & $\mathrm{ND}$ & $\mathrm{ND}$ & $\mathrm{ND}$ \\
\hline $26 / 10 / 2005$ & 64 & 0,17 & 0,23 & 0,45 & 0,34 & 0,16 \\
\hline $9 / 11 / 2005$ & 78 & 0,11 & $\mathrm{ND}$ & 0,04 & $\mathrm{ND}$ & 0,02 \\
\hline $16 / 11 / 2005$ & 85 & 0,08 & 0,09 & 0,04 & 0,05 & 0,08 \\
\hline $30 / 11 / 2005$ & 99 & $\mathrm{ND}$ & $\mathrm{ND}$ & $\mathrm{ND}$ & $\mathrm{ND}$ & - \\
\hline $13 / 12 / 2005$ & 112 & 0,22 & $\mathrm{ND}$ & $\mathrm{ND}$ & 0,13 & - \\
\hline \multicolumn{2}{|c|}{ Média } & 0,19 & 0,18 & 0,29 & 0,26 & 0,23 \\
\hline
\end{tabular}

Tabela A 29 - Concentrações de zinco do esgoto sanitário afluente e efluente dos filtros percoladores $(\mathrm{mg} / \mathrm{L})$

\begin{tabular}{|c|c|c|c|c|c|c|}
\hline Data & Tempo (dias) & AFL & F1 & F2 & F3 & F4 \\
\hline $24 / 8 / 2005$ & 1 & 1,23 & 0,16 & 0,03 & 0,3 & 0,09 \\
\hline $31 / 8 / 2005$ & 8 & 1,03 & 0,43 & 0,46 & 0,7 & 0,56 \\
\hline $8 / 9 / 2005$ & 16 & 0,13 & 0,13 & 0,15 & 0,13 & 0,12 \\
\hline $14 / 9 / 2005$ & 22 & 0,13 & 0,22 & 0,12 & 0,11 & 0,12 \\
\hline $21 / 9 / 2005$ & 29 & 0,47 & 0,45 & 0,47 & 0,44 & 0,45 \\
\hline $28 / 9 / 2005$ & 36 & 0,13 & 0,13 & 0,13 & 0,12 & 0,14 \\
\hline $10 / 10 / 2005$ & 48 & 0,19 & 0,14 & 0,49 & 0,31 & 0,22 \\
\hline $19 / 10 / 2005$ & 57 & 0,08 & 0,32 & 0,09 & 0,18 & 0,03 \\
\hline $26 / 10 / 2005$ & 64 & 0,23 & 0,17 & 0,36 & 0,12 & 0,25 \\
\hline $9 / 11 / 2005$ & 78 & 0,13 & 0,06 & 0,12 & 0,05 & 0,11 \\
\hline $16 / 11 / 2005$ & 85 & 0,11 & 0,1 & 0,08 & 0,07 & 0,11 \\
\hline $30 / 11 / 2005$ & 99 & 0,11 & 0,11 & 0,38 & 0,09 & - \\
\hline $13 / 12 / 2005$ & 112 & 0,17 & 0,06 & 0,08 & 0,20 & - \\
\hline \multicolumn{2}{|c|}{ Média } & 0,32 & 0,19 & 0,23 & 0,22 & 0,20 \\
\hline
\end{tabular}


Tabela A 30 - Concentrações de ferro do esgoto sanitário afluente e efluente dos filtros percoladores $(\mathrm{mg} / \mathrm{L})$

\begin{tabular}{|c|c|c|c|c|c|c|}
\hline Data & Tempo (dias) & AFL & F1 & F2 & F3 & F4 \\
\hline $24 / 8 / 2005$ & 1 & 0,68 & 1,3 & 0,17 & 0,95 & 0,25 \\
\hline $31 / 8 / 2005$ & 8 & 0,98 & 0,33 & 0,34 & 0,17 & 0,45 \\
\hline $8 / 9 / 2005$ & 16 & 1,03 & 2 & 0,2 & 0,05 & 0,32 \\
\hline $14 / 9 / 2005$ & 22 & 0,73 & 3,68 & 0,96 & 1,25 & 0,74 \\
\hline $21 / 9 / 2005$ & 29 & 0,71 & 1,35 & 0,39 & 0,4 & 0,65 \\
\hline $28 / 9 / 2005$ & 36 & 0,4 & 0,82 & 0,19 & 0,18 & 0,68 \\
\hline $10 / 10 / 2005$ & 48 & 0,48 & 0,97 & 0,32 & 0,12 & 0,82 \\
\hline $19 / 10 / 2005$ & 57 & 0,88 & 0,96 & 0,39 & 0,91 & 0,12 \\
\hline $26 / 10 / 2005$ & 64 & 1,89 & 0,31 & 1,16 & 0,75 & 0,09 \\
\hline $9 / 11 / 2005$ & 78 & 0,62 & 0,22 & 0,64 & 0,32 & 0,4 \\
\hline $16 / 11 / 2005$ & 85 & 0,18 & 0,11 & 0,14 & 0,01 & 0,13 \\
\hline $30 / 11 / 2005$ & 99 & 0,45 & 1,18 & 0,72 & 0,31 & - \\
\hline $13 / 12 / 2005$ & 112 & 1,67 & 0,61 & 0,61 & 2,24 & - \\
\hline \multicolumn{2}{|c|}{ Média } & 0,82 & 1,06 & 0,48 & 0,59 & 0,42 \\
\hline
\end{tabular}

Tabela A 31 - Concentrações de manganês do esgoto sanitário afluente e efluente dos filtros percoladores (mg/L)

\begin{tabular}{|c|c|c|c|c|c|c|}
\hline Data & Tempo (dias) & AFL & F1 & F2 & F3 & F4 \\
\hline $24 / 8 / 2005$ & 1 & 0,04 & 0,04 & ND & 0,02 & 0,02 \\
\hline $31 / 8 / 2005$ & 8 & 0,03 & 0,02 & 0,02 & ND & 0,01 \\
\hline $8 / 9 / 2005$ & 16 & 0,04 & 0,06 & 0,01 & ND & 0,01 \\
\hline $14 / 9 / 2005$ & 22 & 0,04 & 0,06 & 0,01 & 0,03 & 0,02 \\
\hline $21 / 9 / 2005$ & 29 & 0,03 & 0,04 & 0,02 & 0,02 & 0,02 \\
\hline $28 / 9 / 2005$ & 36 & $\mathrm{ND}$ & $\mathrm{ND}$ & $\mathrm{ND}$ & $\mathrm{ND}$ & $\mathrm{ND}$ \\
\hline $10 / 10 / 2005$ & 48 & 0,01 & 0,01 & 0,01 & 0,01 & 0,01 \\
\hline $19 / 10 / 2005$ & 57 & 0,04 & 0,02 & 0,02 & 0,01 & $\mathrm{ND}$ \\
\hline $26 / 10 / 2005$ & 64 & 0,04 & 0,04 & 0,04 & 0,05 & $\mathrm{ND}$ \\
\hline $9 / 11 / 2005$ & 78 & $\mathrm{ND}$ & $\mathrm{ND}$ & $\mathrm{ND}$ & $\mathrm{ND}$ & $\mathrm{ND}$ \\
\hline $16 / 11 / 2005$ & 85 & 0,01 & $\mathrm{ND}$ & $\mathrm{ND}$ & $\mathrm{ND}$ & $\mathrm{ND}$ \\
\hline $30 / 11 / 2005$ & 99 & 0,01 & 0,02 & 0,01 & 0,01 & - \\
\hline $13 / 12 / 2005$ & 112 & $\mathrm{ND}$ & 0,01 & $\mathrm{ND}$ & 0,02 & - \\
\hline \multicolumn{2}{|c|}{ Média } & 0,03 & 0,03 & 0,02 & 0,02 & 0,02 \\
\hline
\end{tabular}

Tabela A 32 - Concentrações de cobre do esgoto sanitário afluente e efluente dos filtros percoladores $(\mathrm{mg} / \mathrm{L})$

\begin{tabular}{|c|c|c|c|c|c|c|}
\hline Data & Tempo (dias) & AFL & F1 & F2 & F3 & F4 \\
\hline $24 / 8 / 2005$ & 1 & 0,03 & 0,02 & 0,01 & 0,03 & 0,01 \\
\hline $31 / 8 / 2005$ & 8 & 0,13 & 0,05 & 0,03 & 0,02 & 0,02 \\
\hline $8 / 9 / 2005$ & 16 & 0,2 & 0,03 & 0,06 & 0,06 & 0,09 \\
\hline $14 / 9 / 2005$ & 22 & 0,01 & 0,09 & ND & ND & ND \\
\hline $21 / 9 / 2005$ & 29 & 0,03 & 0,03 & 0,02 & 0,02 & 0,03 \\
\hline $28 / 9 / 2005$ & 36 & 0,02 & 0,03 & 0,01 & ND & ND \\
\hline $10 / 10 / 2005$ & 48 & 0,05 & 0,05 & 0,05 & 0,05 & 0,06 \\
\hline $19 / 10 / 2005$ & 57 & 0,05 & 0,05 & 0,03 & 0,04 & 0,03 \\
\hline $26 / 10 / 2005$ & 64 & 0,07 & 0,07 & 0,03 & 0,04 & 0,04 \\
\hline $9 / 11 / 2005$ & 78 & 0,05 & 0,04 & 0,04 & 0,03 & 0,03 \\
\hline $16 / 11 / 2005$ & 85 & 0,09 & 0,09 & 0,08 & 0,09 & 0,09 \\
\hline $30 / 11 / 2005$ & 99 & 0,05 & 0,07 & 0,07 & 0,06 & - \\
\hline $13 / 12 / 2005$ & 112 & 0,1 & 0,05 & 0,05 & 0,07 & - \\
\hline \multicolumn{2}{|c|}{ Média } & 0,07 & 0,05 & 0,04 & 0,05 & 0,04 \\
\hline
\end{tabular}

